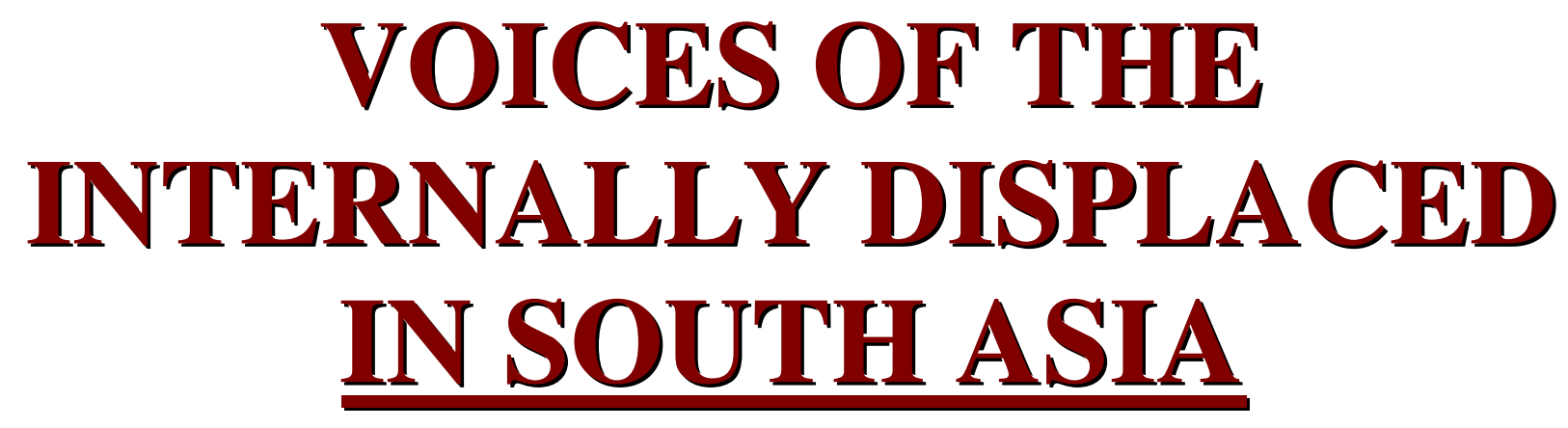

A Report

by

Calcutta Research Group

Kolkata

2006 
December 2006

Published by:

Mahanirban Calcutta Research Group

GC-45, Sector - III, First Floor

Salt Lake City

Kolkata - 700106

India

Web: http://www.mcrg.ac.in

Printed by:

Timir Printing Works Pvt. Ltd.

43, Beniapukur Lane

Kolkata - 700014

This publication is a part of the ongoing CRG-Brookings Institution programme on the Rights and Protection of the Internally Displaced Persons in South Asia. The support of the Brookings Institution for this publication is kindly acknowledged. 


\title{
The Participants of the Team
}

\author{
Suraiya Begum \\ Meghna Guhathakurta \\ Som Prasad Niroula \\ Nir Prasad Dahal \\ Jagatmani Acharya \\ Nirekha de Silva \\ Nilhan de Mel \\ Madhuresh Kumar \\ Asha Hans \\ Amrita Patel \\ Anasua Basu Ray Chaudhury \\ Anuradha Bhasin Jamwal \\ Ramaprasad Bhattacharya \\ Paula Banerjee \\ Ranabir Samaddar
}

\section{Acknowledgements:}

Our debt for this work is to the displaced people we met in camps, villages, and other irregular settlements in different towns of South Asia. We are also indebted to the National Peace Council of Sri Lanka, Colombo, Nepal Institute of Peace, Kathmandu, Research Initiatives Bangladesh, Dhaka, Santa Memorial Rehabilitation Centre, Bhubaneswar, The Kashmir Times, Jammu, and to Jehan Perera in Colombo, Subir Bhaumik and Shreyashi Chaudhury in Kolkata, and to Erin Mooney formerly in the Brookings Institution and now working in Africa. Our debt finally goes to Roberta Cohen who enthused us to undertake the work and stayed with us through with her suggestions and insights. This work is part of the continuing collaboration between the Brookings Institution and the Calcutta Research Group. We acknowledge our debt to the members of the Brookings Team working on the IDPs. 


\section{Contents}

Introduction $\quad 5$

$\begin{array}{lr}\text { I-The Invisible Population } & 18\end{array}$

$\begin{array}{ll}\text { II-Bangladesh } & 30\end{array}$

$\begin{array}{ll}\text { III-Nepal } & 48\end{array}$

$\begin{array}{ll}\text { IV-Sri Lanka } & 67\end{array}$

$\begin{array}{ll}\text { V-India } & 84\end{array}$

$\begin{array}{ll}\text { VI-Some More Statistical Highlights } & 109\end{array}$

$\begin{array}{ll}\text { VII-Recommendation } & 115\end{array}$ 


\section{Introduction}

"Our concerns are immeasurable, but our voice, our views, sensibilities don't matter at all, we know well. We exist or not, does not bother anyone we know that. We're an abandoned lot, uncared for."

\section{Safira Jan, of Akhnoor, Kashmir}

As a result of the ceaseless campaign by the global human rights and humanitarian community - the UN institutions, several national governments, individual human rights and humanitarian groups within countries, and legal and other experts - the task of safeguarding the human rights of the IDPs on a national and global scale has been receiving increasing attention. There have been the Guiding Principles besides the national mechanisms available in many countries. Human Rights commissions, other institutions such as the women's commission, the judiciary, and administrative measures and policies have also contributed to the protection of the rights of the IDPs to the extent possible today.

Yet, amidst all this increasing attention and proliferating measures, few have cared to find out as to how all these measures have benefited the victims of internal displacement - the IDPs themelves. It is important to know their voices so that the humanitarian and protection measures become participatory, these measures can be improved upon, and the human rights community and the public get to know if the measures are effective, if they reach their target at all, and what measures are necessary to make the human rights and humanitarian protection more effective.

Such a task for mapping the "voices" in the region of South Asia was begun by the Calcutta Research Group in collaboration with the Brookings Institution, USA. Conceived in a small South Asian meeting held in Bangkok in March 2005 the project began in August 2005. The initial, time bound pilot study covered select IDPs in Sri Lanka, Nepal, Bangladesh and in four different regions in India. This was meant to be a pilot study carried out in IDP camps in South Asia. The partner organization for this work included:

1 Bangladesh

Suraiya Begum, Research Initiatives, Bangladesh

2. Nepal

Nepal Institute of Peace, Kathmandu

3. Sri Lanka

National Peace Council, Sri Lanka

4 India

Madhuresh Kumar, MCRG, Kolkata, Dr. Asha Hans and Ms. Amrita Patel, Santa Memorial Rehabilitation Centre, Bhubaneswar, Anasua Basu Ray Chaudhury, Centre for the Study of Developing Societies, New Delhi, Anuradha Bhasin Jamwal, Kashmir Times, Jammu and Kashmir

The work combines three methods - (a) random survey of some selected IDP campsites and settlements and analysis on the basis of a focused questionnaire (b) focus group discussions with IDPs living in camps and (c) select case studies and presentations of voices from those selected areas or population groups. A total of 528 respondents from four different countries were interviewed. Other than that a number of focus group discussions were held and over thirty selected cases were studied in depth. There were country reports from Sri Lanka, Nepal and Bangladesh and case reports from Gujarat, Kashmir, Orissa and Bodoland in India. Given below are some of the observations made by the researchers. 


\section{Sri Lanka}

In Sri Lanka Orientation and Training Meeting was held for the Field Researchers on 5 September 2005 at the National Peace Council of Sri Lanka.

\section{Topics discussed during the meeting included-}

$\begin{array}{ll}\circ & \text { Purpose of the Research } \\ \circ & \text { Introduction on the Donor Organization and the Implementing Organization } \\ \circ & \text { Responsibilities of the Field Researchers } \\ \circ & \text { Conducting Interviews } \\ \circ & \text { Conducting Focus Group Discussions } \\ \circ & \text { Conducting Case Studies } \\ & \text { The ethical issues involved }\end{array}$

In Sri Lanka researchers completed hundred interviews. The team working on the project conducted interviews in all the Districts where war affected or Tsunami affected IDPs resided except in Killinochchi and Mullaituv which are LTTE controlled areas. The interviews were conducted in Jaffna, Vauniya, Anuradhapura, Trincomalee, Batticaloa, Ampara, Hambantota, Matara, Galle, Kalutara, Colombo, Gampha and Puttlam. They conducted three focus group discussions. One in Hambantota with Tsunami affected IDPs, one in Puttlam with War affected IDPs and another in Ampara with War and Tsunami affected IDPs. Although 16 was the number expected for the Focussed Group Discussions (hereafter FGD), all FGD meetings exceeded 40 IDPs. The researchers received the support of the Grama Niladharis (Government appointed heads of the villages) and Divisional Secretaries (Government appointed agents of the Divison) to organize the meetings. The meetings were very productive and provided a lot of information needed for the project. The researchers also conducted 10 case studies. Approximately about 4 hours were spent with the person who was being interviewed for the Case Study. In some cases 2 visits were made to gain the relevant information. Among the respondents interviewed Colombo, Galle, Hambanthota, Kaluthara and Matara shows that natural disaster is the most important cause for displacement. In Anuradhapura, Batticaloa, Jaffna, Puttalam and Trincomalee the major cause for displacement was armed conflict.

Tsunami related IDPs in Sri Lanka are recent IDPs and they have been displaced only for one year but war related IDPs are long term IDPs. More than 64 per cent IDPs reported that they have been displaced multiple times. But one positive angle is that more than 90 per cent of those interviewed had received some form of support from either the government or from other institutions. In matters of care for IDPs all replied that they had no knowledge of either local or international mechanisms. In Galle and Colombo a few had replied that they were aware of national mechanisms. This shows that sensitizing IDPs on these mechanisms is a primary necessity. When asked whether the IDPs had any recommendation for international agencies 14.6 per cent replied that more care should be taken in providing social and economic assistance, 11.7 per cent said these agencies should take care of their security needs and 41.7 per cent gave multiple replies.

\section{Nepal}

In Nepal the study was designed to assess human rights situation of internally displaced persons in Nepalgunj where the situation of IDPs is potentially severe. Taking into account the resource limitations, the study was be limited to a purposive sample size of 100 households in three different clusters. Attention was paid to maintain balance in terms of gender, ethnicity (like Dalits) and disadvantaged groups affected from the conflict while conducting the study. Thus, the findings of the study cannot be considered representative of the entire conflict induced IDPs population in Nepal. 
The study focused on identifying needs and aspirations of the IDPs, their access to humanitarian assistance, neglected areas of the humanitarian assistance, their access to education, health, shelter, freedom of movement and other fundamental rights, state' s efforts addressing relief, rehabilitation, resettlement or reintegration and protection issues In this study, 119 respondents were selected for interview in which 57 were from the Rajana Camp (IDP Settlement Area) whereas 62 were selected from outside of the camp, who were residing in different locations of Bardiya district. Nearly three-fourth (73 percent) of the respondents were displaced due to their affiliation to political parties- the Maoists threatened and took into hostile the cadres of political parties, etc. Another important reason for displacement found in this study was poverty (15 percent). About six percent of the respondents were displaced due to natural disaster and about 2 percent were displaced due to development projects. More than 4 percent of the respondents were displaced because their family members were serving in army or police force. Only 35 percent of the respondents expressed that they received support. The remaining respondents clearly stated that they were yet to receive any type of support. Of these respondents, 55 percent received support from the NGO/INGOs and the remaining (45 percent) respondents said that they had support from the governmental organization. More than one-fourth of the respondents stated that they were frequently forced to recruit their children to the armed forces. Knowledge of the respondents regarding UN Guiding Principles on internally displaced persons was found in among 24 percent of the respondents. Most of the respondents have got the information about UN Guiding Principles through media (newspaper reports, radio, TV, etc) and NGO workers. The vast majority (63 percent) of the respondents stated that there was no possibility to return to their homes while slightly over one fourth (26 percent) of the respondents stated that there was still probability in the process. Of those respondents who were hopeful to return to their homes, vast majority ( 87 percent) expressed that the government should initiate the process. The respondents, who expressed impossibility to return their homes, were further asked the reasons behind their assertions. The majority of them expressed that it was due to lack of security.

In addition, five separate focus-group discussions were also held in the study area. The discussions were held in five different groups that comprised of men, women, children, elderly and mixed group of men and women. Each group had 10 to 14 participants with the same characteristics. The discussions were focused particularly on reason of leaving their ancestral place (Where and when, Why), problems (Residence, Employment, Education, Food, Security and Psychological stress) that they were facing, support mechanisms and types of support (Government, Non-government and Civil Society), travel documents (Passport, Citizenship and Other documents), major problems faced by vulnerable groups (women, children, disabled and elderly people), family disintegration, food (nutrition), security, education, health (Prenatal care, infectious diseases), water and sanitation, aspiration of the IDPs (Return to home and Look for normal life), use of property and possessions left behind in habitual place of residence (Land, House, Cattle and Others), discrimination among the IDPs in terms of gender, caste/ethnicity, religion or belief, political or other affiliation, age, disability etc., incitement (State party, Non-state party and others), repatriation, etc. Findings of these discussions clearly indicate the vulnerable condition of each sub-group. Some common feelings emerged in each of the FGDs. There were lacks of adequate food, clothing and shelter, health and education facilities. They also charged that various government and non-government organizations were not serious to deal with the IDPs' problems. Almost all of them have expressed willingness to return their hometowns if the situation turned out to be normal. One positive development of insurgency that has been found in the discussions was the insurgency had contributed to eliminate the caste-based discrimination. Five thematic cases were also collected.

\section{Bangladesh}

In Bangladesh the Paikgacha Upojila of Khulna was selected as the research area because news of conflicts due to shrimp cultivation in this area was mentioned several times in the print media. An 
organization named "Nijera Kori" in Paikgacha (this organization works with the people displaced due to shrimp cultivation) and the leaders of the displaced people have provided us with the whereabouts of IDPs. These IDPs have taken refuge in the different slum areas of the city of Khulna. In reality they are living by shifting from one slum to another.

Kabita Chakma of Khagrachari is herself a member of an internally displaced family. She was born and brought up in Khagrachari and she knows the district very well. Moreover she is directly connected with the movement of the hill people so she has thorough knowledge about IDPs of that area and the incidences that created them. This was very helpful in selecting respondents. Also Raja Debashish Roy of Rangamati has helped Tarun Bikash Chakma in selecting IDP respondents. He pointed out the habitats of Chakma and non Chakma populations i.e. Tripura, Marma, Pangkho etc. Moreover the leader of 'Janashanghati Shamiti", Shaktiman Chakma has also helped in this regard. This is how the respondents were selected.

The Bangalee IDPs are well known as settlers in CHT. But even these Bengali settlers have been victim of a number of incidences and have become IDPs several times. The unstable political situation of CHT has played a major role here. The Bengalis of CHT are divided into three categories, original residents, settlers and non-settlers. The Bengali settlers mainly dwell in the "Gucchagram" or cluster villages. All the dwellers of these cluster villages have come from other places to live here. So it was easy to find IDP respondents here.

The researchers as expected faced some problems while selecting the respondents. They had to verify the IDPs of Khulna to find out whether they were really displaced due to shrimp cultivation or any other reason. It was found that in several cases the IDPs were really displaced due to terrorism or due to river erosion. Moreover the IDPs have now become day laborer or rickshaw puller, so they were not always available. Many of them asked that whether any developmental step was being taken for them.

Most of them have heard the term "displaced" for the first time. The proble $\mathrm{m}$ in Khagrachari was that, the research assistant, Kabita Chakma, was once the president of Hill Women's Federation and was directly involved in politics. The participants of FGD were selected among the respondents. The FGDs were carried out during afternoon or evening. The discussion was carried out among 7-10 people. The discussion took place sometimes in the courtyard, sometimes in the market. Availability, especially of the male respondents, was a problem. In all the cases people other than the respondents took part in the discussion. In many cases the help of the local Headman or the commissioner of the locality was needed.

Many non governmental organizations (NGOs) like BRAC, ASA, Proshika are working in Khagrachari. Besides, other small local NGOs also work here. The people who live in the Dighinala residential school building get ration from the government. In Doshar, Rangamati Unicef and the Government of Bangladesh are carrying out some work on sanitation and health. There was no NGO activity in the slum areas of Khulna. "Nijera Kori", the NGO runs some motivation and awareness program in Shathikunia and Mohammadnagar area. In this program there is no other chance of monetary help, the IDPs are now attracted towards the micro credit program.

Since shrimp cultivation is mainly done in the coastal areas of Khulna most of the developmental IDPs were from this region. Shrimp cultivation was done in the low lands along the banks of rivers before the implementation of the costal embankment project in the 50s. Later the project created stagnancy in the low lands, which created a difficulty for cultivation of crops. From then on these areas belonged to shrimp gher (farm). In the late 1970 these became shrimp farms due to international demand. So the practice of using lands for shrimp cultivation extended to Shatkhira, Khulna and Bagerhat districts. Eventually agricultural lands were being used as shrimp farms. According to a calculation of UNDP and FAO, it was estimated that by the year 2005, 1, 29,530 acres of land would come into the purview of shrimp 
cultivation. But in reality, 1, 38,000 acres of land was being used for shrimp cultivation by the year 199495. This rapid growth rate of lands being used for shrimp cultivation increased the percentage of IDPs in this area. Because there is a rule in these areas that if an owner owing 85\% land of an area agrees to lease his land for shrimp cultivation then the owners of the other $15 \%$ lands are bound to lease their lands too. Otherwise the person who is taking the lease can flood the whole area with salt water. Most of the owners of these shrimp farms are outsiders and influential businessman. They maintain a good relation with the local influential people and the administration. They influence the local administration and with the help of local terrorists, overpower the landowners and establish shrimp farms. All these factors play role in creating internally displaced people. The small peasants or day laborer lose their land in the shrimp farm. Then they have to leave in pursuit of work. More over less working force is needed in the shrimp farms than in the agricultural field. So the excess laborers become IDPs and come to the city..

The first important thing that comes into focus is that many of them have become IDPs in the first place due to river erosion. There is an interrelationship among shrimp cultivation and river erosion. As the southern area of Khulna is included in the polder, the water flow here is regulated by sluice gates. The owners of the shrimp farms create sluice gates by cutting the WAPDA (Water and Power Development Authority) dam according to their own need. These gates are of lower quality than those build by WAPDA. So sometimes these gates break down during high tide and cause flooding inside the polder and causing more people to become IDPs.

Internal displacement in the Chittagong Hill Tracts occurred during the armed conflict from the mid1970s to 1997. The violent conflict in the Chittagong Hill Tracts between the 13 different ethnic groups and the Bengalis of the plains has been the root cause of one of the largest occurrences of internal displacement in Bangladesh. This spanned over three decades until an accord was reached between the armed wing, the Jana Sanghati Saiti (JSS), demanding autonomy of the jumma (slash and burn cultivators), and the Bangladesh government in 1997. A Government Task Force estimated that as of July 2000, 128,000 families were internally displaced in this region. The three decades of forced evictions, terrorization as part of counter-insurgency techniques and planned settlements of plains land Bengalis in the CHT have caused havoc in the life of people who refused to flee to India. After the accord many refugees have come back to find their land taken away and occupied by Bengali settlers and military. They now join the ranks of the internally displaced.

In total six FGDs were done in the CHT. Women groups and male groups were done separately. Research assistants carried out these FGDs mainly on the basis of availability. Discussion of the women group was carried out in the East Narankhaiya village of Khagrachari. They stated that they have been displaced several times. At first it was in the year of 1960 when they were displaced due to the bulding of Kaptai Dam in Rangamati. Then they built their habitat in Larmapara, Narankhaiya and Logang area of Khagrachari. Then they were displaced due the mass killing in Panchari and Logang. At that time many of them crossed the border and went to the neighbouring country of India. This was the incidence of 1986-89. Then after the peace treaty in 1997, they changed their habitat back to Bangladesh and built their homes in the present location. They have identified different reasons for their displacement. Conflict among the army and the Shantibahini, mass killing, order of the army to leave the place, collaboration of the settlers Bengalis with the army in disowning them of their houses etc. are some of the reasons. The movement of the indigenous hill people to establish their identity and rights and the oppression of the local army have created an unstable situation in the CHT. Armed conflicts are at large here. The indigenous people keep moving from one place to another to protect their existance. Some of them left the country and became refugees in India. Most of them have built new habitat inside the CHT.

The main problem of being displaced was the problem of residence. When they left they had nothing to take with them as either it was burnt or they were too afraid of their lives to take anything. They had to face problems with employment, education, food, security, mental stress. Those who were displaced due 
to the Logang mass killing underwent a lot of stress. They were always tensed whether Bengalis will come again to kill them. As the night fell, they felt that death was roaming around them. Those who became refugees had to live a terrible life. They had to depend only on the ration as they had no employment.

While talking about the help they got, they stated that government has never offered them any help and their voices were ignored. But their relatives and the civil society have helped them. The IDPs had no documents when they were roaming from one place to another. They were only trying to survive then. Even when they were refugee in India, they had no documents. When they returned a government list was made. Only those whose names were mentioned there were able to come back.

\section{India}

In India four different cases of displacement were selected. These are cases of massive displacements for different reasons. In Jammu and Kashmir displacement has occurred due to state verses community and community verses community conflicts. More recently displacement has occurred due to India-Pakistan conflict and massive mining in the border region. In Gujarat displacement has occurred due to the genocidal attacks against the Muslims in 2002. Orissa has witnessed massive displacement due to reasons of development. One of the first group of dam oustees is in Orissa and they were displaced because of the building of Hirakud dam. In Assam displacement has occurred both due to conflict and development. Here the situation of people displaced due to conflict is desperate as these people are languishing in camps in such as those in Kokrajhar without any help from local, national or international organizations.

\section{Jammu and Kashmir}

On the basis of the team's visit to border villages of Akhnoor (Garar, Samwa, Chapriyal and Sainth) and Poonch (Birhuti, Degwar and Kerni), besides two camps for displaced persons at Akhnoor, the survey and group discussions with the displaced persons has led to the following observations:

There are broadly three different categories of displaced persons in Jammu along the international border and the disputed Line of Control (LoC) between India and Pakistan.

1. Those living in camps or in rented accommodation at their own expense way from their villages.

2. Those who are dispossessed of lands that have been mined and fenced out.

3. Those whose entire village has been fenced out. They have access to their fields and homes in the mornings and afternoons but are forced to return back to what are called cluster colonies, usually 2 to 6 kilometers away from their fields and homes.

The border people living in the camps in Aknoor, about 40 kilometers from Jammu city were displaced in 1999 in the wake of Kargil war when the maximum brunt was borne by inhabitants of 21 villages comprising 6,070 families. Heavy shelling, mortar firing by the Pakistani soldiers and mining operations in their fields by Indian soldiers virtually left them homeless. They spent the first six months huddled in school buildings or government complexes in Akhnoor town with no relief in terms of food or health care. Six months later, the camps came up at several places on the outskirts of Akhnoor - three of which are still existing, two only partially. These comprise about 1,500 families.

Rest of the people went back to their villages in phases, some in 2004 and others in the summer of 2005. But the return has not been totally voluntary. An element of coercion and the unfulfilled promise of demining their agricultural lands and providing compensation for the damaged houses by the civil administration has been a major reason for the return. The people were finally forced to return after the 
government forcefully shifted the schools and primary health centres and dispensaries from the camps to the villages. Out of these 21 villages on the zero line, some on the international border and some falling on the disputed Line of Control, two villages are totally empty - Chaprayal and Samwa. Both these villages are on the LoC.

The Centre has announced a package of Rs 78 crores for the border people from just these 78 villages, out of which Rs 22 crores is already released. Much of the money is likely to be spent on constructing permanent safe shelters for these villagers, on the reconstruction of their houses, (an amount which has already been disbursed but found inadequate), schools and medical health-care infrastructure. Some relief in terms of rations and meager cash doles was received by these people till last year. Some months back, the government announced extension of free rations for a period of another year, ending September 2005. Most villagers, both those living on the camps and in the villages, said that they were not receiving this ration or they had received it only for two months.

In the twin border districts of Rajouri and Poonch, the situation in 45 border villages is alarming. They have been totally fenced out in the recent fencing operations by the Indian army (2004) and their lives are under total control of the army, the virtual absence of the civil administration in these areas adding to their woes. The fencing, which is 6-7 kilometers inside the Line of Control restricts their movement and they are totally isolated from rest of the country. And, that alone is not their sole concern. As per a central government plan in 2001 to relocate the villages from the zero-line to the interiors, Kerni, a village comprising 106 families, in Poonch tehsil becoming the first target, cluster colonies have now come up in most of these 45 villages. The cluster colonies are located 4-6 kilometers distance from the zero-line as well as their homes and fields.

This is a hilly area where population is scattered across the mountain range. Several of these villages were bifurcated into two by the Line of Control in 1948 or by minor adjustments ever since. Most of these villagers have divided families, some members living on the Pakistani side of Jammu and Kashmir. These villages have witnessed periodic displacements since 1948, the biggest one in 1965; mostly people intimated by the army have crossed over to the other side. During the last sixteen years of militancy, these border villages, some of which are known to be popular infiltration routes have borne the brunt. The consequent increase in army's repressive measures has led to frequent displacements to the other side, though there are minor cases of some of them returning as well. The zero-line is excessively embedded with mines and casualties are 5 to 10 percent in almost all the villages, besides killing and maiming of cattle and sheep.

The fencing and cluster colonies have compounded the problems of the people who have already tasted the bitter pill of government neglect, as well as poor or negligible roads, health and education facilities. The people's lives are under army's surveillance all the time and they are expected to be back befor e dusk in these cluster colonies. They go every morning to their fields and homes, which may be a good one and half hours walk for some, work the entire day and must report back in the cluster colonies by the evening. The timings are arbitrary as per the whims of the army units in the area - in some cases, the villagers are expected to be back by 4.00 P.M. The only job that the civil administration did was to allot small pieces of land for construction of one room tenements per family in these cluster colonies for the people and announce Rs 1 lakh each family for the construction of the same. The full payment has not been released in most cases and some people have regretted the level of corruption involved, or the disregard for the latest census, depriving some of these people of any funds. The health facilities are poor and educational facilities, barring a few villages, is not quite up to the mark. The villagers are totally dependant on the army for their needs and it all depends on the whims of the unit officers posted there to help them with medical health-care or educational facilities. 
While the basic cause of the displaced community at the borders in these villages remains the same army conflict and, or, army occupation, the nature of their problems varies. Deprivation of land, and denial of health-care facilities as well as education is common to all - but the extent of this varies. This comparative study as well as problems related to gender and children will be taken up in the final research paper.

\section{Gujarat}

In Gujarat the researcher visited three districts namely, Ahmedabad, Vadodara, and Godhra to assess the situation of IDPs in Gujarat. She met 50 persons and talked to them personally, who are still trying to resettle themselves in the places like Bombay hotel surrounding area, Jamalpur, Faizal Park, Ektanagar (Batwa) in and around Ahmedabad, and 101 Colony and Falah Nagar in Halol, Kashimabag Housing Society in Kalol and Navinagri in Godhra. All of her respondents were Muslims except one, who was a Hindu dalit. She had 10 male respondents and the rest were female. Out of these women, 22 were married, 1 unmarried, 3 separated from their husbands and 14 widows. Apart from them, a rape victim, whom she met at Kashimabag near Kalol bus stand, was kind enough to share her painful experiences with her. Being displaced from her original home at Delol, she took shelter in one of the makeshift camps in Kalol and from the camp she was rehabilitated in the Kashimabag Housing Society with the help of the NGOs.

Interestingly, almost all the respondents in Gujarat were critical about the government help. They expressed that; initially the government did nothing to save their lives during the turmoil and when they were lucky to find shelter in the camps established by the community organisors with the help of the NGOs they only received some bad quality food grains and vegetables from the state government. In this context, it is to be kept in mind that, according to one estimate, initially one hundred fifty thousand (government figure was much less than this) people were displaced and took shelter in one hundred and twenty-one makeshift relief camps (mostly set up by the community organisations and NGOs) located in and around the affected areas. Even after the killing and displacement of many, the Gujarat government refused to provide any assistance to these hapless people. In short, the basic humanitarian concerns of these displaced persons were entirely ignored. The widow respondents of Kashimabag told the researcher that, the government granted Rupees 1,50,000 for the death of a person during the communal violence and they as the family members of the dead person received one-third portion of this amount in cash and rest in the form of the certificate of government bonds. The release of the money for the death compensation depended on the production of a death certificate, which often became difficult for these people to deliver. As a result, some of the families of the same neighbourhood did not even receive any compensation from the government.

From the extensive evidences recorded by the researcher, it is clear that the Muslims from all social strata, rich and poor, were the prime targets for the state-sponsored pogrom unleashed in different parts of Gujarat. Only in a few cases, some Hindu establishments were also targeted in the cities of Ahmedabad and Vadodara..

Women and young girls were targeted brutally, as were children. Rape became the means of the systematic violence. While sharing their nightmare experiences with the researcher some of the women victims have described how the terrorised women of their own areas were forced to parade naked through the neighbourhood; victims were urinated upon, before being finally cut to pieces and burnt and how the whole episode of killing left an ineradicable imprint on the minds of the survivors, who saw their near and loved ones killed and, that too, in such a fashion. However, the violence of 2002 forced women to come out of their traditional household domain. Women became more vocal and conscious about their rights and they came forward to take part in the betterment of the community in their locality. In fact they were taking part to run the self-help groups, schools and even local community health clinics. 


\section{Orissa}

The socio economic condition of Orissa is based on a high poverty ratio ( about 50\%). The New Economic Policy along with Liberalisation, Privatisation and Globalisation has created a situation in the state where industrialization and large projects has become the thrust of the Govt. Mining, dams, industry is causing displacement in thousands without creating necessary social nets which will safe guard the interests of the people. The state has no R \& R Policy though recently ( 2005 ) it is being drafted along with some civil society agencies and UNDP. It is hoped that the voices of the people will find a place in the new policy. As of now the compensation and rehabilitation package has been devised on a case to case basis either by the Govt or the company ( public or private ) on the numerous development induced displacement. There is no uniformity in the rehabilitation policies in the various developmental projects in the state. The different projects have followed different norms. The Water resources department of the Govt of Orissa however has had a rehabilitation policy since the first instances of displacement in the state has been due to the mega dams and the irrigation - hydel power projects.

Statistical figures indicate that till 2000 in Orissa, about 20 lakh people have been directly affected by development projects in varying degrees out of which about 5 lakh have been physically displaced losing their home \& hearth from their original habitat. Statistical figures further indicate that while Dam/Irrigation Projects alone have displaced nearly 3.5 lakh people out of the 5 lakhs which is roughly $70 \%$ of the total displaced persons, Industrial Projects have displaced about 60,000 people which is $12 \%$ of the total displaced, Mining Projects $-3.37 \%$, Urban Development Projects- 12.86\%, Thermal Projects$2.60 \% \&$ Wild Life Sanctuaries $-0.5 \%$. Although the above referred figures account for the already completed projects, there are a host of other projects which are either ongoing or are in the pipeline in which about 2 lakh more people are expected to be displaced.

This project on Recording the Voices of the IDPs have been conducted amongst the displaced persons (women) due to the Hirakud Dam constructed on the river Mahanadi in Sambalpur district, the coal mining by Mahanadi Coalfields Limited (MCL) in Jharsuguda district and the Ib Thermal Power Station (ITPS) of the Orissa Power Generation Corporation (OPGC) in Jharsuguda district. All the respondents and case studies are located in the various villages, camps, and resettlement colonies of Lakhanpur block of Jharsuguda district of Orissa. While the displacement due to the dam happened way back in 1950s, the other two cases of MCL and ITPS are recent i.e. in 1990s. Some of the women displaced due to Hirakud dam have also been affected ( not displaced ) due to ITPS. This study captures the voices of the women displaced due to all the above three instances and doubly affected due to ITPS.

The Hirakud dam project in Orissa was the first major multipurpose project that was executed in post independent India as a part of the planned development process. It displaced 22,144 families from 249 villages in Orissa ( 108 fully and 141 partially ) and 36 villages ( 3 fully and 33 partially ) in Madhya Pradesh ( total 285 villages ) comprising of 1,10,000 population. The vast artificial reservoir submerged 74,300 ha of land including 23,988 ha of forest cover and 49,888 ha of agricultural land. The Mahanadi Coalfields Limited ( a subsidiary of Coal India Limited ) started open cast coal mining in the Ib valley since 1985 acquiring 926.6 hectares of land. It prepared a resettlement and rehabilitation policy of its own for those who have been forcibly displaced due to the mining operations. There are 5 open cast mining projects which have affected 18 villages and 1353 families. The Ib Thermal Power Station has been established in the Ib Valley coal mining region at Banaharpali (now in Jharsuguda district ) by OPGC. 329 families were affected by the project in 3 villages out of which 146 families have been fully displaced. According to reports 169 families have been resettled in colonies. 
The questionnaire has been done for 50 women respondents as per the following details -

\section{Location}

a. Adhapara Camp village

b. Sri Jagannath resettlement colony

c. Sri Ganesh resettlement colony

d. Shapara colony
Cause of displacement

Hirakud dam

MCL coal mining

MCL coal mining

MCL coal mining
Number of Displaced

25 nos

10 nos

12 nos

3 nos

The case studies are from displaced women due to MCL coal mining, ITPS and Hirakud dam.

\section{Bodoland in Assam}

MCRG conducted the fieldwork in Kokrajhar and adjoining districts of Bongaigaon, and Dhubri in Assam, North East India. The survey included the meetings with the IDPs due to ethnic violence in the Bodoland Agitation between Bodos, Adivasis and Muslims. The focus group discussions and interviews with men and women were conducted in the region at the campsite. Northeast India has witnessed protracted conflicts and displacements of thousands of people in the last few decades. In Assam in Northeast India in the last count (August 2004) a total of 37,677 families (2,37,768 people) were staying in makeshift camps in three districts of western Assam - Kokrakjhar, Bongaigaon and Dhubri. These IDPs are all but forgotten. The displacement in these areas has happened due to an ethnic community claiming exclusive rights over a space that it defines as its "homeland" on the ground that it is the "original inhabitant" of the land. By the same token, they have held that outsiders have no right to settle there.

The Bodo community comprises the majority in Kokrajhar district. It also has a sizeable Rajbongshi and Santhal population in addition to Muslims, whose fast increasing population is generally attributed to the infiltration from Bangladesh. Kokrajhar is now the headquarter of the Bodoland Autonomous Council created in 1993. Kokrajhar was originally a part of undivided Goalpara district. Earlier a sub-division was upgraded to the status of district on $1^{\text {st }}$ of July 1983. After further reorganisation the present geographical area of Kokrajhar district is estimated to be 3,169.22 square km.

The ethnic cleansing started with large-scale attack on Muslims of Bengali descent in October 1993. These migrants, mostly of peasant stock, had taken over land throughout Assam, initially causing displacement of ethnic Assamese and the tribal peasantry. In the 1980s the Assamese agitators targeted them and a decade later became the targets of the Bodo militants. This continued in 1994 and resulted in massacre of around 100 Muslims mostly women and children, and some 20,000 were displaced in Kokrajhar and Bongaigaon districts. In 1995-96 Bodo militants started attacking the Bengali Hindus and finally in May-June 1996 launched massive attacks on the Adivasis throughout western Assam. However, unlike Muslims, the Adivasis and Bengali Hindus formed their own militant groups and started attacking Bodo villages. The Adivasi Cobra Militants of Assam (ACMA) and Bengali Liberation Tigers, a group formed by Bengali Hindus teamed up and attacked several Bodo villages after the massive Bodo sponsored violence of May-June 1996. After this initial outbreak conflict between the two ethnic groups became a regular feature in western Assam. In 1998, the violence intensified just when some of the displaced people were returning home. Thousands fled their villages again, exacerbating the displacement. Hundreds were reportedly killed, thousands of homes destroyed, and many people of both communities displaced. The Assam State government brought in military forces to quell the rioting, and over 250,000 people took refuge in 68 relief camps. 
After 1993, the Bodos have systematically targeted the non-Bodo communities in the four districts they see as forming the core of their separate homeland. Having got the structure for a future homeland, but one which is still heavily populated by non-Bodos, the Bodo militants have resorted to systematic attacks on non-Bodo communities to further their strategy of ethnic cleansing. The Bengalis, Hindus and Muslims who control prime agricultural land (that they cleared and worked in) and the retail businesses, are also the prime targets of ethnic cleansing in the Bodo-areas of Assam.

- The latter half of the 1990s saw the mushrooming of militant organisations along tribal, religious and cultural fissures. The culture of violence propagated by the ULFA and the Bodo outfits seems to have set a pattern for a number of copycat insurgent groups. Till a few years ago, there were as many as 34 insurgent groups listed in the State, though the ULFA is the main player. Among other terrorist outfits, the National Democratic Front of Bodoland (NDFB), Bodo Liberation Tigers (BLT), United People's Dem ocratic Solidarity (UPDS), Dima Halim Daoga (DHD), and Muslim United Liberation Tigers of Assam (MULTA) are prominent. The NDFB operated in the Bodo-areas of the State and the UPDS dominates the Karbi-Anglong and North Cachar districts. Most of these organisations are dormant after Delhi government signed an autonomy agreement with the Bodoland Liberation Tigers (BLT) in 2004 and opened dialogue with the National Democratic Front of Bodoland (NDFB) in 2005. The elections has now been held for the BTC areas and BLT occupies the power, even then an uneasy peace prevails in the region now.

- In 1997, the majority of the refugees returned to their original villages and homesteads, with government provided rehabilitation grants. However, 23,000 families, designated "encroachers" (illegally occupying homestead lands), were unable to return. In addition, there were about 3,000 families who - despite having received rehabilitation grants - were unable to return to their original homes, living in small huts made of bamboo and plastic sheeting, close their to their original villages or on relief camp sites. However violence erupted in 1998 on two occasions, causing people to once again flee to the safety of the camps. More than 110,000 people from the Santhal-Bodo conflict still remain in relief camps. Assam officials say only about half of the quarter million displaced people were still left in makeshift relief camps. Assam government records, as of December 2005, indicates that only 33,362 displaced people were left in the camps Kokrajhar district and 74,123 were left in the camps in Gosaigaon district. According to official reports of in January 2004, 19 camps house Santhals, 3 house Bodos and one houses the Rabhas ethnic group.

The field research and interaction with the IDPs completely demystified the claim of the state government that they have been rehabilitated. It was observed that in some cases the second generation of IDPs were in camps and who had no access to basic amenities. They had no access to education and health facilities. If the ground realities are improving with peace prevailing after the accord but the fear is still there in the minds of Santhals who are yet to take charge of their lands. Many of them are still staying away from their villages and visit there only during day and return to safer Adivasis villages. In fact the violence has made all the parties involved more conscious and aware of their ethnic identities and caused further polarisation.

\section{Cumulative Findings from the Four Regions in India}

In India among all the respondents over 68 per cent were women. Over 59 per cent of all respondents were illiterate. Over 50 per cent of the families had more than five members of whom over 65 per cent were adults. Also most families had over 2 children. Over 45 per cent of all respondents were domestic or agricultural labourers and only 4.9 per cent were working in the industrial sector. An overwhelming number of the respondents (53.4 per cent) earned less that Rs. 1000 a month. More than 45 per cent were displaced due to armed conflict and army occupation and 23.3 per cent due to development projects. 
Over 80 per cent reported that they have not come from their original place of residence and 46.6 per cent have suffered multiple displacements. 55.3 per cent reported that they got no material support from any organizations and governments provided for only 13.1 per cent of all respondents. 78.6 per cent of the respondents reported that they were in poor health condition and 84 per cent reported that no help was available for either the pregnant or the elderly. Over 50 per cent reported that they were overwhelmed by economic problems and 28.6 per cent, largely those who were displaced due to armed conflict, said that they suffered from lack of security. 73.3 per cent reported that they had no probability of return. Almost all who were displaced due to development projects knew that they have no hope for return. Respondents who were displaced for reasons of development reported that they could not return to their original place of habitation largely because of loss of livelihood and those who were displaced by armed conflict said they could not return for lack of security.

\section{Findings from the Four Countries}

- Of the 528 respondents 235 were displaced due to armed conflict, 34 due to army occupation, 91 due to development projects and 66 due to natural disaster.

- The profile of a total of 528 respondents portrayed that 352 were women (women and girl children). This was not completely accidental as each researcher was expected to interview at least 50 per cent women. Among all the respondents 41.9 per cent were illiterate and 7 per cent could barely read and write. Only 4.2 per cent had gone beyond high schools. The respondents were largely married. Over 85 per cent of all respondents were married. Most families had (70.8 per cent) had more than two adult members living in the same household. Also over 60 per cent of the respondents had more than two children. Over 44 per cent were in the domestic sector and over 49 per cent earned less than Rs. 1000. Over 44 per cent of all respondents were displaced due to armed conflicts and about 17.2 per cet were displaced due to developmental projects. Over 47.3 of the respondents were displaced for more than five years and 68.2 per cent had to undergo multiple displacements.

- About 52.7 per cent received some support and 46.6 per cent received none. Government provided support to only 20.6 per cent of the respondents and NGOs and INGOs to 13.8 per cent of the respondents. About 33.5 per cent received multiple forms of support with only 10.6 per cent getting any support for food. 59.7 per cent received no support for education of their children.

- Only 19.5 per cent of all children were working of whom the majority were in the industrial sector although only 5.9 per cent of all adults were in the industrial sectors.

- About 64.2 per cent of the respondents were faced with poor health conditions Most of the respondents (48.7 per cent) visited government run hospitals in times of need. Also more than 71.8 per cent of the women received no support during pregnancy.

- Perhaps more worrying is that 43 of all respondents reported that children were habitually recruited for the purpose of armed conflict.

- Among the problems faced by IDPs was the slim possibility of return. About 68.6 per cent reported that there were no possibilities of return. 75.6 per cent of the respondents faced restrictions in movement and 47.2 per cent faced economic problems. 
- As for policy mechanisms only 1 person responded that s/he had knowledge of any national or international mechanisms for IDPs. About 36.2 per cent gave multiple answers but 291 respondents reported that they have never heard of any mechanisms for IDPs. Over 67 per cent had no knowledge of UN Guiding Principles and only a few respondents from Sri Lanka responded positively to this.

- Among those who were educated over high school level none felt that there could be adequate compensation for displacement. They spoke largely for security and economic and social assistance but knew that this was no compensation for the trauma suffered.

- Most number of IDPs are involved in domestic work. Only 31 of the 528 respondents were in industrial labour. This portrays that it is a myth to suggest that development related IDPs are also beneficiaries of development projects.

- South Asian trends portray that only those who are displaced due natural disaster have any hope of being rehabilitated within one year. 156 of those who are displaced due to armed conflict are in the state of displacement for more than five years. 60 of those who are displaced by development projects are living as IDPs for more than five years.

- Among the 235 respondents displaced due to armed conflict 149 are women, among the 91 respondents displaced due to development projects 71 were women and among the 66 displaced due to natural disaster 30 were women. This substantiates the hypothesis that the largest group of IDPs due to armed conflict and development are women. Also an overwhelming number of these women (186) are illiterate. Only 11 of all the women interviewed had gone beyond high school.

- Over 10.5 per cent of all women interviewed were widows. Both their lack of education and their status as widows added on to their vulnerability in a region such as South Asia.

- 68 per cent of all working as domestic labourers were women. In absolute terms 139 women worked as domestic labourer and only 11 as industrial labour. This translates to the fact that only 3.1 per cent of women IDPs were in industrial sector. 53.1 per cent of the women interviewed had income of less than Rs. 1000 (slightly over \$2) a month. This portrays that most IDP women lived in abject poverty.

- 276 of the 352 female respondents have lived the life of IDPs for more than 3 years. 70.8 per cent of all the IDPs questioned who have lived as IDPs for more than 5 years are women.

- 64.8 per cent of all IDPs facing multiple displacements were women. Only 17.6 per cent of women respondents got any support from governments compared to 26.7 per cent of the men.

- Over 236 women, i.e. 67 per cent stated that they suffered from poor health conditions. 46.6 per cent women reported that they went to government health centres. More than 75.9 per cent of all women reported that no support was available for either the pregnant or the elderly. 


\section{The Invisible Population}

'While women around me were usually kept busy by their families, I could only si t around and watch with nothing much to do. Earlier, it used to bother me because I have never been the kind to sit with hand over hand. It felt like I had my hands tied on my back and no one could untie them. However, gradually, I came to terms with the reality and credit also goes to my neighbours in the camp, who come to spend time with me whenever possible." Lajwanti, a camp inmate in Jammu in India

\section{Method}

In pursuing the work on recording the voices of the displaced population groups of South Asia the areas were randomly selected. ${ }^{1}$ But mostly these were the camps of the displaced in different parts of the region - in Southwest Nepal, in India in four different parts (in the north, west, east and in the northeast), in two parts of Bangladesh (northeast and south) and in Sri Lanka in the east and south.

There was of course some principle, and it operated like this. Two cases of study were selected in Bangladesh - one where displacement had occurred due to violence and the other where displacement occurred due to development activities and environmental degradation. In Sri Lanka again two cases or two groups of cases were selected - one involving victims of earlier displacement due to civil war and the second group related to displacement due to Tsunami. In Nepal the case selection was made keeping in mind the massive dislocation in western Nepal where displacement due to civil war and violence have been acute. Finally in India the select cases bear in mind the various reasons of displacement - thus in Jammu and Kashmir the specific cases were selected because they showed the nature of displacement due to massive militarisation of border. Gujarat was selected because it has been one of the most well known instances of displacement due to religious violence. Orissa was selected so that the study could include the experiences of people displaced due to random development activities such as indiscriminate mining and consequent environmental degradation. Finally we had to include one case from the North-east because here the displaced have been living for a longer period of time, some around 6 years, also it is in the North East - the densest zone of displacement in the country. In total 528 people were interviewed. In Bangladesh 100 people were interviewed, in India 206, in Nepal 119, and in Sri Lanka 103 people. These are not to be treated as sample but cases selected for study due to a variety of reasons and now the entire corpus of cases and studies constructed and presented here in their own right. The quantitative data gathering was followed by the collection of qualitative data gathered through focused group discussions, inclusion of life studies, etc. In selecting places and groups, while we located the camps to be studied, we were aware of the problem that if this was to be a sample-wise study, given the fact that there is hardly a consistent registration policy regarding the internally displaced persons (IDPs) in any one of the countries of South Asia, and that many, many of the IDPs throughout South Asia have been living with their families, there would have been an unmanageable wide variation in different databases. In some cases the Government does not have any policy of acknowledging or admitting "internal displacement" as a legal administrative category at all. Thus we had to adopt a pragmatic method, not the best one certainly, that of visiting camps mostly in these areas wherever they were accessible, and other identifiable displaced groups in identifiable areas (as in Bangladesh) and following up on these cases by focus group discussions and individual case studies wherever necessary to throw light on the data gathered.

This study should therefore be considered as a pilot survey, which hints at certain trends and features and suggests the need for deeper enquires into the fundamental issues of rights of the displaced, responsibilities of the states and the international community towards the victims of displacement,

\footnotetext{
${ }^{1}$ Pakistan was the only country left out not as a matter of design of the study, but due to several constraints of management and resources.
} 
questions of representation, citizenship, democracy, and sovereignty. It would be unfair to dismiss the conclusion that emerges from the data, group discussions, and individual case studies as not indicative of a larger reality. In such a huge region as South Asia where on the one hand displacement occurs continuously and massively, and on the other hand there is huge ignorance about the phenomenon with the administration trying at times to wish it off or pushing it under the carpet to a sub-phenomenal existence, the survey speaks a lot, and speaks out a lot; The lives studied here are worth listening to in their own right. They are not mere numbers or representative samples of bigger numbers. Finally the merit of the study lies in the fact that there is a South Asia study - it covers a region divided into many countries but having strong social and political similarities. Haunted by war, violence, rape, repeated man-made and natural disasters, and homelessness, the lives of the displaced people recorded from all across South Asia have many a common story to tell.

\section{State of Displacement - A State of Exception?}

Of course, the first issue is how the displaced stay, the state of displacement. What does state of displacement mean? Are we to give it a definition, legally phrased (let us say the Guiding Principles on the IDPs and their rights), and externally registered? The legal and externally given definition is there. Or, are we to see it as a state in which some groups of population find themselves - hence the state is as how they state. Hence is the issue of the voices. But voices are not opinions, they are not proclamations, they are not eloquent, but neither are they silent, pre-meditated, un-meditated, unmediated, and mysterious internal thoughts. They are the in-between, the middle space, the first open space of autobiographies, and therefore the first biographies of the spaces the owners of the voices occupy. Thus voices and camps have a strangely intimate relation. Camps (the ones we are speaking of here, not the Nazi death camps) are neither legal nor purely informal; they are neither places of death nor are they places of living and settlements; they are not places of detention and rescue, nor are they the sites of gradual extinction. These are therefore the fertile sites of voices - which are neither planned nor pre-meditated, neither a chorus nor a cacophony, neither a litany of complaints and woes, nor a list of despair and hopelessness. In this first discernible site of agency of the displaced as it emerges, voices and camps function as each other's perfect duo. In a way, this is reflective of the larger process of the emergence of the political subject - no a priori theoretical ground, no intellectual mapping of the emergence, but actions, acts, and voices - the first sign of the emergence of the subject out of the invisible population groups existing as the sub-stratum of a heavily supervised, governed, administrated, and watched earth. It is the camp that has to be investigated first, because the camp is the place indicating a stigma around the duty to protect a group, which at once is designated as "weak" - a group that is "vulnerable", a "victim", that has no right to be heard, no right to autonomy, no way to be considered as author of own "voice" and hence cannot be the author of decisions concerning them. What this indicates is the void in the mechanics of representation, on which democracy depends. Protection becomes in this way the apogee and the low point, the nadir, of the liberal constitutional state. It is a demonstration of what the state can do to you and its effect is to create a generalised fear about the infinite and random power of the mighty to destroy lives, and an intense sense of vulnerability in victim populations. Government actions, public laws, and administrative measures carry a mark of legitimation of harshness used to enforce state power - to protect or to kill. This means state sanctioned detention and confinement of the victims in order to protect a vulnerable group is now on the political agenda. The camp thus to recall Giorgio Agamben's argument in Homo Sacer is the "threshold". Though Agamben used it in a different context, what does this mean for us? As readers will see when they go through the details that follow,

1.The original political relation is the state of exception as a zone of in-distinction between outside and inside, exclusion and inclusion.

2. The fundamental activity of sovereign power is to protect life but in a way as if it could protect life by producing "bare life" only. 
3. The camp is thus the bio-political paradigm of modern governmental power; lives of families, victims, direct victims, their children and their men and women, - all these are lumped together in this bio-political existence, which acquires its specific character of existence through the governmental function of protection. Protective camps are the sign of modernity; they are the modern form of what Michel Foucault called the "pastoral power".

Protected but not improved, maintained but fed and clothed at a bare level, herded together in a shelter but the armour of gender, age, or physical and mental inability taken away, the physical lives in the camps as the following pages will testify are the classic case of administrative convenience and the fusion of legality and semi-legality on which administrative power thrives. Camps represent therefore a form of political authority that owes its origin in the function of setting up camps, and as we shall see this authority not only survives but is able to create a situation whereby issues of justice and injustice are suspended, because administrative rationality suggests a fusion of normal and abnormal; and this is a fusion on which sovereign power will depend. Producing hierarchies of vulnerability, governmental power through the function of care, erasing large sections of population by herding them in camps, and by maintaining these huge numbers as the sub-terrain existence - the political authority produces at once three things: (a) administrative power of enormous consequence; (b) the zones of "terra incognita" beyond law, legality, and responsibility - hence zones of unaccountability in a democracy; and (c) a discourse of humanitarianism that is not at odds with governmental power but fits happily with the latter, in fact reinforces the latter. In this scenario where the "normal" is gone and you are only in the state of being "abandoned", law produces its void. Law gives up, yet in a way that no body says that it has failed. Thus law is not asked as to why is this scenario where rights have been taken away, only camps remain the sign of authority and responsibility. Law vanishes without a trace of being castigated for its failure to protect citizenship. Thus the impossible has been achieved: power and myth of law remain; groups of people have been excluded in a way as if they have been included; and politics has been foreclosed.

Yet, how does one escape the aporia? Here is the significance of the voices - the ethics of agency on which politics can reconstruct. Politics begins with the emergence of the political subject, and the political subject can emerge only under the conditions of ethical responsibility of bearing testimony (to the conditions of bare life). Ethical responsibility to bear testimony stands out here against the juridical irresponsibility evident in "abandoni ng" the displaced. In this form-of-life (the camp), where the "state of exception" has turned into normality, politics faces in a miniaturised form what it would be soon facing on a broad scale, namely, that the society is a hybrid of law and fact, and that each time it escapes a crisis, it does so by manufacturing a new juridical-political paradigm in which law has become indistinguishable from the exception. There the "voices" are the only counterpoint in the form of an oppositional testimony. ${ }^{2}$ How else can one explain what happened to the victims of the Gujarat riots, the hundred of displaced along the mined borders in the north of India, or the inmates of the camps in Bodoland in the north-east surviving for years? Each time the society has been fractured each time the solution has come in form of banishing the victims from the visible world. Yet, testimonies remain. Therefore, we thought in planning this exercise that a quantitative method was not enough, the very select South Asia-wide survey and the statistical analysis needed to be supplemented by reports of group discussions, key informant interviews, and most importantly, a phenomenological analysis of what the terms often employed in international and national administrative-humanitarian and legal and para-legal discourses have meant to the inmates of the camps who are at times survivors of repeated displacements.

\footnotetext{
${ }^{2}$ In this context one can read Ulrich Raulff, "Misery Knows no Law", German Law Journal, 5, May 2004 - book review of Georgio Agamben's The State of Exception (2005)
} 


\section{The Right to Return - A Void in the Legal Discourse}

The void in the legal discourse as brought out in the testimonies, termed collectively in this report as "voices", points to one more important thing, namely how the British common law system is ineffective in redressing situations of forced displacement and subsequent camp confinement in the name of protection or impoverishment as these. Not only as these responses show, the right to return though theoretically guaranteed cannot be lawfully implemented - which is why camps persist, and on this a moment later - but on all significant related issues such as education, health, privacy, sexual rights of women, property, work opportunities, the common law system provides no relief, amelioration, and escape. That is because protection is strictly legally bound, protection is legally defined, and is a legal duty, with the consequence that what law cannot, anything else will not be allowed to achieve. The development of a modern legal system and the implementation of the common law have long been noted as benefits of British colonisation. But in all cases of expropriation of property of the small people like the peasants or urban small businessmen and artisans, common law could not come to the rescue of these petty propertied people. Rioters could not be punished, guilty police officers and administrators could not be brought to book, looted property could not be restored, and a "fast, fair and affordable" legal system offering redress and justice remained a far cry for the displaced. Colonisation is the dominant experience of countries with common law; and the common law was almost everywhere imposed rather than organically developing. Thus it left everywhere people in need of justice in despair. To get a raw account of that - the failure of law - we need to read the interviews and the autobiographical accounts.

Before moving onto the other salient features of this chronicle of voices, let us refer to the absent "right to return". If we speak of the refugees, the displaced and then migrating under duress and seeking asylum elsewhere, we know that they enjoy very few rights of which the right to return is but one of the most intrinsic. Although much debated internationally the right to return is most clearly enshrined in the 1966 International Covenant on Civil and Political Rights (ICCPR) under its provisions on the right to freedom of movement (Article 12.4) which says that No one shall be arbitrarily deprived of the right to enter his own country. But this right has often proved to be a chimera. This is often true of the internally displaced also. The IDPs as citizens should have the right to return to their original places of home and work. But as this study shows, the South Asian experiences of the displaced peoples' right to return remain an empty one. On the basis of these studies one can say that the polities have acquired nation form on the basis of the denial of the right to return. The nations have become homogenous in such ingenious way. The denial of the right to return developed on the strength of precedence. Perhaps the first group of people whose right to return was denied by a South Asian state were the Indian emigrants who travelled abroad in the eighteenth and nineteenth centuries to work as plantation labourers. All through the nationalist period the fate of these labourers in their country of domicile was a rallying point for Indian leaders to portray the dark side of foreign rule. There was constant reiteration that they state was responsible for all the people who were born in India. Yet during the Central Legislative Assembly debates in 1944 the leaders came to a consensus that these émigrés belonged to their country of domicile and not rightfully to India. Unlike nationalists during the colonial period, the leaders of the post-colonial State formation project no longer looked forward to the return of the emigrants who were slowly being considered as foreigners.

We can take a well-known precedence: The independence of the sub-continent was accompanied by a blood bath. The partition of India and Pakistan resulted in two million deaths and about 15 million people were displaced. Most of the refugees were lucky enough to get domicile and often citizenship in their country of domicile. Yet problem arose over the issue of return. In people's memory their Desh (country) was where they were born. But once displaced they did not have the right to return even when they so desired. Legislations were passed whereby the property of the displaced were confiscated by the state and treated as enemy property. The home they wanted to go back to remained only in their own imagination. One of course hears the argument that because partition refugees got alternate citizenships they lost the right to return. In South Asia there are however other groups of refugees who remain as stateless people 
and are denied the right to return. Two groups of refugees are prominent in this respect: the Chakmas (Jumma people) of the Chittagong Hill Tracts now settled in India and the Southern Bhutanese now in camps in Nepal. ${ }^{3}$ These precedents help us to understand as to the context in which the right to return becomes a chimera, a context produced by the most extra-ordinary juxtaposition of one hand the nationalising polities, fictive ethnicities, discourse of homogenous citizenship, and on the other hand the histories of aliens, half-citizens, exiles, refuge-seekers, illegal immigrants, - in short, those who are beyond the pale of citizenship rights, and who are not even the proper subjects of the international law. In this physical milieu of expulsion, de-enfranchisement, and nationalisation, the right to return is at once the most crucial question and the most hallucinatory claim for the displaced. The main question simply will be: Can we realise this right in the present state system? What can be the juridical guarantee rules of a right to return that would nullify the right to expel? And what can be the possible politics where accommodation can take the place of marginalizing places, names, communities, bodies, and existences? In a situation where expulsion of peoples is the norm rather than being an exception, where the pure space of exception has got to be de-naturalised, that is to say be returned to its status of being an exception, what can be the politics of an exile or a camp inmate, the survivor, who has been pushed to zones of invisibility, who must now become visible in order to make claims on the political society? This report is one such attempt to restore visibility to invisible population groups.

\section{Dense Invisibility}

Think of the denseness of invisibility. We are speaking here of the generation that lost land and everything in the wake of the first flush of industrialisation in independent India - we are speaking of the invisibility of the displaced due to construction of the Hirakud dam in Orissa. Statistical figures indicate that till 2000 in Orissa, about 20 lakh people have been directly affected by development projects in varying degrees out of which about 5 lakh have been physically displaced losing their home \& hearth from their original habitat. These figures further indicate that while dam/irrigation Projects alone have displaced nearly 3.5 lakh people out of the 5 lakhs (roughly 70 percent of the total displaced persons), industrial Projects have displaced about 60,000 people which is 12 percent of the total displaced, mining projects have contributed to 3.37 percent, urban development projects 12.86 percent, thermal Projects 2.60 percent, and wild life sanctuaries 0.5 percent. Although the above referred figures account for the already completed projects, there are a host of other projects which are either ongoing or are in the pipeline in which about 2 lakh more people are expected to be displaced. The phenomenon is thus obviously massive, yet what accounts for its invisibility? Procedures, and procedures make them invisible. Thus the moment the ousting "developmental" project commences, all public eyes are on the "development", not on the cost. More significantly, since this is just a "cost", statecraft and governmental procedures reduce cost to compensation, rehabilitation, and resettlement, thus turning the entire thing into a game with the government and the plant owners trying to minimise "cost" as much against a weakened and displaced claim making group of people. It is a bargain, the banality of which is unsuitable to catch the public eye and become visible, unless someone dies (the number should be more) in the process, or there is breakdown of law and order, or a sit-in strike, and a counter-violence, which we may choose to call mimetic violence. And then, time takes toll. Banality increases, the sheer banality of evil to use the words of Hannah Arendt is able to escape society's censure and redress. Invisibility becomes in course dense.

The voices of the displaced women in the wake of the construction of the Hirakud Dam on the river

\footnotetext{
${ }^{3}$ On these two cases, Tapan K. Bose and Rita Manchanda (eds.), States, Citizens and Outsiders - The Uprooted Peoples of South Asia (Kathmandu: South Asia Forum for Human Rights, 1997); Subir Bhaumik, Meghna Guhathakurta, Sabyasachi Basu Ray Chaudhury (eds.), Living on the Edge - Essays on the Chittagong Hill Tracts (Kathmandu and Calcutta: South Asia Forum for Human Rights and Calcutta Research Group, 1997); also various reports and articles in Refugee Watch
} 
Mahanadi in Sambalpur district of Orissa way back in 1950s give us ample thought on the entire process of invisibility. The displaced women are located in the various villages, camps, and resettlement colonies of Lakhanpur block of Jharsuguda district of Orissa. As we know, the Hirakud dam project in Orissa was the first major multipurpose project that was executed in post independent India as a part of the planned development process. It displaced 22,144 families from 249 villages in Orissa (108 fully and 141 partially) and 36 villages ( 3 fully and 33 partially) in Madhya Pradesh (total 285 villages) comprising of $1,10,000$ population. The vast artificial reservoir submerged 74,300 hectares of land including 23,988 ha. of forest cover and 49,888 ha of agricultural land. Numerous researchers have pointed out that the number of persons displaced by the Hirakud dam was between 1.1 lakh and 1.6 lakh, while the official figure was only 1.1 lakh. As the displacement in case of Hirakud happened as early as 1956, a sum of only Rs 340 lakh was paid to the oustees out of the Rs 960 lakh allotted. Out of the total displaced families only 4,744 families (21.42 percent) were rehabilitated. Out of the families rehabilitated 3,098 families (65.3 percent) had not got full compensation till as late as 1990s. This report tells us of 25 displaced women mainly from Adhapara Camp village besides telling us of the other women displaced due to cal mining and power project construction. In these village-camps the villagers including the women have been forced to change their occupation due to land alienation. The irony is that the village has the Hirakud dam reservoir on one side and the power plant (ITPS) on the other but the village has no electricity, no safe drinking water source and no irrigation facility for whatever marginal cultivation is done at the periphery of the village. The women of this village have been subjected to police atrocities and also jailed when they protested against the ITPS establishment in 1990. The report tells us of Kamala Bhua, aged about 65 years, presently residing in the Adhapara camp village who was displaced due to the construction of the Hirakud dam. She was barely 10 years old when all her family members had to leave their homes carrying just a trunk on their heads. Her village was fully submerged due to the dam and they were not in a position to carry all their belongings. They all settled in the Adhapara camp. She grew up and was married to a boy from a family, which too was displaced, and was staying in the same camp, Her parents in course died, her brother also died. She has faint memories of her original village, but she was old enough to remember the hardship her family had to endure in the new location. The whole area was a jungle; there was no food or water available for days. It was a long time before her mother could start a kitchen to start cooking. She as a young girl went to the jungle to look for edible fruits and roots. Today she has her sons and daughters. But disaster struck her again when the OPGC (Orissa Power Generation Corporation) started acquiring land for the ITPS (IB Thermal Power Station). The Adhapara camp was again to be dislocated. The villagers, both men and women, got together and protested. Kamala Bhua took a lead role in the protest, and she along with 50 other women was imprisoned in the Sambalpur District HQ jail for more than a month. The villagers courted arrested and the administration was not in a condition to tackle such a law and order situation. Finally the ITPS was forced to abandon this camp village for its purpose of acquisition. Kamala is of course cynical when one talks about displacement and about the usefulness for recording her narratives.

The invisibility is denser when the displaced are scattered, and only in a scattered state they can survive. Take the case of the invisible displaced population in Khulna of Bangladesh. The Paikgacha Upojila (subdivision) of Khulna (district) was selected as a study area because news of conflicts due to shrimp cultivation in this area was mentioned several times in the print media of Bangladesh. People displaced due to shrimp cultivation there have taken refuge in the different slum areas of the city of Khulna. In reality they live by moving from one slum to another, because there too they do not get permanent place to stay or their changing daily occupations take them from one place to another, reducing them to vagabondage. There the people are displaced for more than one reason - besides shrimp cultivation, in several cases displacement was due to terror, violence, and or river erosion. And as the report wryly puts it, "Most of them have heard the term "displaced" for the first time".

Shrimp cultivation is mainly done in the costal areas of Khulna. Shrimp is one of the major export products of Bangladesh. According to the experts, shrimp cultivation in Bangladesh started in 1929-30 in 
the Sundarbon (famous mangrove forest of the deltaic region of the eastern part of South Asia) area. Shrimp cultivation was done in the low lands along the banks of rivers before the implementation of the costal embankment project in the 1950s. Embankment in course brought in stagnation of water in the low lands, which created a difficulty for cultivation of crops. From then on these areas belong to shrimp gher (farm). In the late 1970 these became shrimp farms due to international demand. So the practice of using lands for shrimp cultivation extended to Shatkhira, Khulna and Bagerhat districts. Eventually agricultural land was increasingly used as shrimp farms. The rate of extension of lands being used for shrimp farms was 16.6 per cent till 1982-83 to 1988-89. According to a calculation of UNDP and FAO, it was estimated that by the year 2005, about 1,29,530 acres of land would come under shrimp cultivation. This rapid rate of increase of land being used for shrimp cultivation resulted in an increase in the percentage of the internally displaced also in this area. With the unwritten rule to the effect that if an owner owing 85 per cent of an area agrees to lease his land for shrimp cultivation then the owners of the other $15 \%$ lands are bound to lease their lands too, peasants and farm labourers have been increasingly displaced. There is always the threat that the person taking the lease can flood the whole area with salt water. Most of the owners of these shrimp farms are outsiders and influential businessman. They maintain good relation with the local influential people and the administration. They can overpower the local peasants and establish shrimp farms. All these factors play role in creating internally displaced people who now come to the city. The same fate has happened to the Paikgacha of Khulna. People of Paikgacha now live in the slums of Batiaghata of the same district. But the slums are also not permanent. So they shift from one slum to another, from one profession to the next. Some of them have become industrial labourers; some have become rickshaw pullers. In this way most have melted away amidst the vast impoverished masses of the country.

There is an interrelationship among shrimp cultivation and river erosion, which also leads to displacement. As the southern area of the district of Khulna is included in the polder, the water flow here is regulated by sluice gates. The owners of the shrimp farms create sluice gates by cutting the WAPDA (Water and Power Development Authority) dam according to their own need. These gates are of lower quality than those build by WAPDA. So sometimes these gates break down during high tide and cause flooding inside the polder. In the year 1989-90, the entire No 32 polder was flooded in Dakop Upojila. In that season, not a single farmer of Kumarkhola or Sutarkhali union was able to grow paddy. That was the first time when a lot of people became displaced in this area. At first these displaced people bought lands in other areas around and restarted their life there. They were hopeful that someday possibly be a new land (char) will rise in the eroded area and they would get their land back. With this hope these people started living in the Kumkhali area nearby to Paikgacha. Then shrimp cultivation started in this area too. These marginal farmers could not cultivate shrimp due to lack of land or capital. As a result they had to sell their habitat or the small amount of land they owned, and their ultimate destination was the city. After that they began living an insecure life. They could not establish any permanent way of income or residence. They became members of the multitude - invisible from the public eye.

The report tells us of the small farmer Habibur Rahman of Batiaghata narrating almost this same story. He came from village Kumkhali of Paikgacha. He was a successful seasonal farmer in Kumkhali before shrimp cultivation started there. After it began in Kumkhali he lost his means of earning livelihood one by one as cultivation of any kind of crop became impossible. So he had to come to Khulna. He got a job in a medical clinic named Nirala. His wages were not enough to meet all the needs of his family, so poverty became his constant companion. Now living in city, they thought that they would be able to send their children to the government primary school. But the children could not continue education up to secondary or higher secondary level due to poverty. They dropped out. The displaced do not have any documents regarding this, neither they need these, because the displacement process is seen as "natural" and therefore invisible. In the slum areas, water supply and drainage system is a grave problem. They may complaint, but they do not have any hope of going back to their "original state". Many of them sold their original habitat or left it to near relatives before moving out. In some cases, they either leased it out or 
sold it. People having cattle or poultry sold them before shifting. As IDPs they now live in slum areas, practically deprived of civic rights. Political parties, both the government and the opposition, of course ask them to attend their meetings according to their own need. There are always assurances given. They may not have hope; but they have to go there in hope of getting something. Meanwhile, they have to live in the same room. Their married children, grand children all live in the same room, so there is no question of privacy. People like Khodam Ali, Bojlu, Nur Ali have no work at the villages. So they cannot go back even if they want to. Amin's mother thinks that as they lack a permanent address, nobody trusts them. Luckily the government hospital is nearby; at least pregnant women have some hope of being attended. In Khulna, the women state to our researchers the condition of displacement as matter of fact; they are more curious to know whether this research will do them any good or not.

In the Chittagong Hill Tracts (CHT) in Bangladesh the indigenous women respondents were however quite emotional. They had tears in their eyes; their pain was evident in their faces. They wanted to know if those happy days of their pre-conflict past would ever return. The conflict between the State and the indigenous people of the CHT had resulted in significant displacement of the indigenous people. In many cases Bengali speaking people from the plains had been settled in the Hill Tracts to permanently displace the local communities and reduce them to a minority, so that the state engaged in the numbers game implicit in a deadly ethnic battle can win. Yet as the case of the CHT shows, the environmental and political factors behind displacement often are mixed with each other. In the responses of the displaced in the CHT the reason for displacement development projects come out as a main cause. These projects include the construction of Kaptai dam, and once again shrimp cultivation, though the immediate and possibly the main reason of displacement has been army occupation and armed conflict. Government and non-government support to some extent arrived later - government relief mainly in form of rationed provisions, relief material, money, and land for resettlement, and non-governmental help mainly in form of credit. Some non-government organisations (NGOs) started their work in CHT after the peace accord was signed in 1997. Their work includes education, credit, housing loan, water sanitation etc. In some areas the IDPs do not live in camps, and there is no definite support system for them. However, they get health and education service from local hospitals. In most of the cases the last displacement occurred 5 years ago and 40 per cent of the displaced has been displaced more than once. This is significant as in the case of Bangladesh, 52 per cent of the respondents are household heads; 39 per cent belongs to the age group of 40-59 years; 51 per cent women; and 40 per cent illiterate. Equally significant is the fact that 70 per cent are married; and 47 per cent of the respondents belong to the "others" category of job/occupation - thus "others" includes housewives, dependant, and Union Parishad (local government) member. The significance is that repeated displacement is a general phenomenon, and not an exceptional one.

Yet, when we come to think of the issue, should we be surprised that the terms Internally Displaced Persons (IDPs) is a new "phenomenon" to the respondents. They have not heard about any national or international policy mechanism or the Guiding Principles on the IDPs. People just do not know what this means, which is why many respondents did not answer the concerned question, or just said that they did not know what it was. So we have a high percentage of NA (no answer) and NC (no comment). Dense invisibility is an insufficient term for not only the displaced are in many ways invisible, state policies do not reach them. So do not reach international principles, norms, and laws.

\section{A General Scenario}

On many of these features of the state of displacement, South Asia presents a general situation. Far away from the south east of the Bangladesh on the east of the region of South Asia is the Jammu border area in the north of the region separating India from Pakistan. Yet, in the border villages of Akhnoor or Poonch, where heavy militarisation of the border (mining, fencing, army occupation, exchange of artillaey fire, requisitioning of village provisions, encampment, etc.) has led to large-scale displacement, whose detailed findings this report carries, we have again the same features, though in this case in an exacerbated form. 
People are living in camps or in rented accommodation at their own expense way from their villages, and are now dispossessed of lands mined and fenced out. In some cases entire villages have been fenced out. The villagers have access to their fields and homes in the mornings and afternoons, but are forced to return back to what are called cluster colonies, usually 2 to $6 \mathrm{~km}$. away from their fields and homes.

The border people living in the camps in Aknoor, about $40 \mathrm{~km}$. from Jammu city were displaced in 1999 in the wake of Kargil war when the maximum brunt was borne by inhabitants of 21 villages comprising 6,070 families. Heavy shelling, mortar firing by the Pakistani soldiers and mining operations in their fields by Indian soldiers left them homeless. They spent the first six months huddled in school buildings or government complexes in Akhnoor town with no relief in terms of food or health care. Six months later, the camps came up at several places on the outskirts of Akhnoor - three of which are still existing, two only partially. These comprise about 1,500 families. Many of course went back. Out of the 21 villages on the zero line, some on the international border and some falling on the disputed Line of Control (LoC), two villages are totally empty - Chaprayal and Samwa. Both these villages are on the LoC. At 80 percent of the people who have returned to their villages are dispossessed of their agricultural lands, and it is important to point out that this area is agriculturally rich and farming has been the mainstay. The villagers have no access to the mined fields, which are also fenced out by the recent fencing operations on the borders. Several cattle-heads have become casualties due to the mines and the fencing restrictions pose their own kinds of problems.

Once again, in the camps major problems are schooling and health related. Readers will find the details in the following pages. The electric supply and water supply to the make shift camps were discontinued. The matter has become a major bone of contention not just between the displaced persons and the government, but also the two major political parties in the area - Congress and BJP. Besides, land mafia, grabbing and encroaching on the land with the patronage of some officials are also present. Once again, some relief in terms of rations and meagre cash doles arrived later. Most villagers, both those living on the camps and in the villages, said that they were not receiving this ration or they had received it only for two months. The situation is alarming in 45 border villages in the twin border districts of Rajouri and Poonch. This is a hilly area where population is scattered across the mountain range. Several of these villages were bifurcated into two by the Line of Control in 1948 or by minor adjustments ever since. Most of these villagers have divided families, some members living on the Pakistani side of Jammu and Kashmir. These villages have witnessed periodic displacements since 1948, the biggest one in 1965; mostly people intimated by the army have crossed over to the other side. During the last sixteen years of militancy, these border villages, some of which are known to be popular infiltration routes have borne the brunt. The consequent increase in army's repressive measures has led to frequent displacements to the other side, though there are minor cases of some of them returning as well. The zero-line is excessively embedded with mines and casualties are 5 to 10 percent in almost all the villages, besides killing and maiming of cattle and sheep. Government relief trickles in at times - the amount heavy in promise, little when it actually reaches the villages. The situation in Kokrajhar, one of the twenty-three districts of Assam and described as the gateway to the north eastern region of India, is neither different.

In the 1980s the agitators in the Assam anti-immigration movement targeted the non-Assamese inhabitants who a decade later became the targets of the Bodo militants. It continued in 1994 and resulted in massacre of around 100 Muslims mostly women and children, and some 20,000 were displaced in Kokrajhar and Bongaigaon districts. In 1995-96 Bodo militants started attacking the Bengali Hindus and finally in May-June 1996 launched massive attacks on the Adivasis throughout western Assam. However, unlike Muslims, the Adivasis and Bengali Hindus formed their own militant groups and started attacking Bodo villages. After the resultant displacement many returned. But about 23,000 families, designated "encroachers" (illegally occupying homestead lands), were unable to return. In addition, there were about 3,000 families who - despite having received rehabilitation grants - were unable to return to their original homes, living in small huts made of bamboo and plastic sheeting, close their to their original villages or 
on relief campsites. Violence erupted again in 1998 on two occasions, causing people to once again flee to the safety of the camps. More than 110,000 people from the Santhal-Bodo conflict still remain in relief camps. Assam officials however say only about half of the quarter million displaced people were still left in makeshift relief camps. The features of these camps are once again the same.

In Nepal, as in Bodoland in Northeast India, there is no unanimity over the figures of the internally displaced. This is partly because of the open borer with India. Many of the people displaced from MidWestern districts (Accham, Jumla, Kalikot, Mugu, Humla, Pyuthan, Rolpa, Salyan, Rukum, Dailekh, Surkhet, Jajarkot, Bardiya and Banke) fled to Nepalgunj seeking for a safe-shelter within Nepal, but many fled to India also across the border too. Of total number of 119 respondents, one-third of them are completely illiterate and 8 percent can read but cannot write. More than two-fifth of the respondents (41 percent) are unemployed, followed by domestic or agriculture labour, fishing, dairy (39 percent). About 17 percent of the respondents are engaged in small income generation schemes (shop keeping, vending etc.) and negligible proportion (3 percent) of them is engaged in industrial sector (mechanic, guard etc.). The majority of the respondents (68 percent) have less than Rs. 1000 monthly earning for their livelihood; they are the very poor.

Once again, the reasons for displacement are mixed. While nearly 73 percent of the respondents say that they are displaced due to armed conflict, 15 per cent puts it to poverty; and about 6 percent says the reason to be natural disaster. One-third of the respondents have suffered from multiple displacements - the highest percentage of duration of displacement is for 1-3 years and near about one-fourth of the IDPs remains displaced for 4-5 years. Nearly 65 percent of the respondents have not received any type of support. The IDPs of Nepal in that sense remain in the abyss of condition, and invisibility.

\section{Inclusion/Exclusion (I/E)}

Is this invisibility a state of exception? Persons who cannot be sacrificed but can be killed or silenced as in these cases not only prove the nature of our polities, and the nature of the invisibilities in our democratic polities, they also show how in modern times inclusion and exclusion operate as twin strategies of governing the people. After all Agamben's mysterious figure of Homo Sacer looming large through centuries of history remained inscrutable; the requirement of sovereignty made the to be killed-atwill figure both necessary as a figure to be included in the society while excluding it at the same time. The camps of these report, the empty villages, and the slums where the displaced live, bereft of even the minor protection that a refugee gets, are there in the society, yet they are out of the society, to be discounted in silent embarrassment to our democracies.

Is there any out of this situation of inclusion/exclusion? We must not ignore the basic fact of general poverty and dispossession of people of resources that works as the most salient factor in the entire operation of I/E. The general inability means that once a section of population is pushed to the margin, it is difficult for them to come back to the mainstream of life - not only because they start living in camps (the mark of invisibility) but because these camps and other such settlements of terra incognita, devoid of even elemental educational and medical care facilities (for instance in Sri Lanka, the report points out that there was no support from the government for sending children to school), symbolise the target of governmental strategy, namely that sections of population groups are to be included, yet they will be kept in a state of exclusion, a classic case of $I / E$. Displacement repeats in such situation. Of such situation we can say that not only vulnerability leads to displacement, but that the state of displacement is the greatest situation of vulnerability, which causes the victim to become victim again. Similarly discrimination leading to displacement is reproduces itself in a like manner; displacement now creates further discrimination (for instance Santhals and Muslims in Bodoland in Assam). Can they begin a "hew" life? When democracy cannot ensure conditions the return of the displaced, will the policy henceforth be one of making them take a new "turn", that is to say resettlem ent rather than return? We can say at least this 
that in all these cases, policies must have options, opinions of the victims must have a critical place in the formulation of policies, policy mechanisms must be built on consultation processes and provisions, and in all these cases the non-governmental organisations or the government units working below are often powerless in front of the fundamental governmental strategy of I/E. In this scenario small things become crucial not only as physical realities of life, they are the stark reminders of the deficit of democracy. Democracy is a story of normal conditions. And, we are led to believe that under abnormal conditions it may not function. Thus in a state of displacement, which is an abnormal condition, violence will occur as in camp life at each micro level and moment, it will be a life without care - thus no health facility, no educational support, no extra food, no aesthetic delight, etc.

Yet we know two things: first, even in camps human efforts redeem, and even these camps generate political activities combining legalities and semi-legalities; and second, the camp at times reflects the larger, that is the normal, condition. Living in camps, a general state of dispossession and displacement, and always remaining a target of policy and administration - is that not life in general? What is exception and what is the rule? Similarly what is visible and what is invisible? And, say, what then is the challenge for democracy?

\section{A Select Profile of the Survey of the Displaced Population of South Asia}

\section{Sample Size:}

$\begin{array}{lll}\text { India } & : & 226 \\ \text { Bangladesh } & : & 100 \\ \text { Nepal } & : & 119 \\ \text { Sri Lanka } & : & 103\end{array}$

Sample sizes are small in respect of the total population of the countries. It is unlikely therefore to say that quantum of samples in each country will be representative of the whole population. It may be suggested to say that the samples have been collected from the conflict zones of the countries and the samples have collected from those zones on a 'purposive sampling basis'.

\section{All Countries - Some Highlights}

- Age: As age is concerned, a large percentage (74.6\%) belong to the age group 25-29.

- Literacy: A large percentage of the sample individuals are illiterate (41.9\%)

- Marital Satus: Almost all the sample individuals are married (85.4\%)

- Family Members: $51.8 \%$ of the families have got members between 5-8

- Adult Members: Among the sample households 70.8\% members are adult

- Children: Children in the family between $2-5$ age group is $60.4 \%$, whereas below 2 age group it is $22.9 \%$. Thus the percentage total up to the age 5 comes to $83.3 \%$

- Current Occupation: Occupation in the domestic level is $44.1 \%$ and in the industrial sector it is $5.9 \%$. In 'self trade' the figure is $7.2 \%$, though the kind of trade is not defined anyway. In another category 'others', though the percentage is relatively high $(38.1 \%)$, but the nature of occupation remained unknown. 
- Current Monthly Income: Percentage of current monthly income is in the group 'Below Rs.1000' (49.4\%). Assuming the family size as 4.5 (as defined in the census), the per capita monthly income in this group comes to a about Rs.222/-

- Causes of Displacement: Most of the displacement occurred due to armed conflict (44.5\%) and then comes due to development project (17.2\%). Thus the percentage amount of displacement due to armed conflict and the development project is really an accountable figure $(80.5 \%)$

- Duration of Displacement: The duration of displacement 'above 5 years' high enough (47.3), whereas 'between 3-5 yrs' it is quite low (26.3\%). These two total 73.3.

- Direct Journey: A large percentage of sample population (68.2) are drifting from one camp to other which should be considered for their permanent rehabilitation, or return to their original place.

- Major Concerns: 'No concern', 'Lack of security', Lack of amenities, accounts to 20\%, whereas 'No application' accounts to $64.6 \%$ (Why?). In fact there are no facilities are available, in the true sense, in these camps.

- Problems Faced in the Region: The major problem faced by the people in the camps is the 'economic problemes' (47.2\%). The picture is clear if one goes through the monthly income level of the amilies.

- Restriction is Movement: About $3 / 4^{\text {th }}$ of the respondents $(75.6 \%)$ are in favour of 'No'. The percentage of answer is so high because they might be thinking that there is no chance of return to their habitual place and as such they have make a society of their own in the camp.

- Probability of Return: A high percentage (68.6) of the respondents think that there is no possibility of return. This may be cross-checked with 'Direct Journey From The Habitual Place' and 'Duration of Displacement'

- Agency Responsible for Return: Actually there is no rigidity in the answer given to this question. Only a small percentage (16.7) of the responding people responded that the 'Government' is the responsible agency for their return. 


\section{Bangladesh}

'When we were refugees we had to use a stream running nearby as our toilet. For drinking water we dug holes in the land. Kala-azar was endemic in the camp. Every day five to six people were dying. We lived in the refugee camp for three year and almost 2000 people were dead by then in this disease. There were not enough doctors. They seldom gave us medicine. Our only thought then was whether we would be able to go back to our country. When I went to sleep I thought about these things. I thought what would I eat tomorrow and this thought of an uncertain future used to keep me awake all night. In my thought I returned to the same question again and again, when will I return home?" Gopa Debi Chakma, CHT, Bangladesh

In Bangladesh, the Paikgacha Upojila of Khulna was selected as the research area because news of conflicts due to shrimp cultivation in this area was mentioned several times in the print media. An organisation named Nijera Kori in Paikgacha (which works with people displaced due to shrimp cultivation) and the leaders of the displaced people provided us with the whereabouts of IDPs. These IDPs have taken refuge in the slum areas of the city of Khulna. They have to shift frequently from one slum to another.

Kabita Chakma of Khagrachari is herself a member of an internally displaced family. She was born and brought up in Khagrachari and knows the district well. Moreover, she is directly connected with the movement of the hill people, so she has thorough knowledge about IDPs of that area and the incidents that created them. This was very helpful in selecting respondents.

Raja Debashish Roy of Rangamati has helped Tarun Bikash Chakma in selecting IDP respondents. He pointed out the habitats of Chakma and non-Chakma populations, i.e., Tripura, Marma, Pangkho, etc. The leader of Janashanghati Shamiti, Shaktiman Chakma, has also helped in this regard. This is how the respondents were selected.

The Bangalee IDPs are well known as settlers in CHT. But even these Bengali settlers have been victims of a number of incidents and have become IDPs several times. The unstable political situation of CHT has played a major role here. The Bengalis of CHT are divided into three categories: original residents, settlers and non-settlers. The Bengali settlers mainly dwell in the "Gucchagram" or cluster villages. All the dwellers of these cluster villages have come from other places to live here. So, it was easy to find IDP respondents here.

The researchers, as expected, faced some problems while selecting the respondents. They had to verify the IDPs of Khulna to find out whether they were really displaced due to shrimp cultivation or any other reason. It was found that in several cases the IDPs were really displaced due to terrorism or river erosion. Moreover, the IDPs have now become day labourers or rickshaw pullers, so they were not always available. Many of them asked whether any developmental step was being taken for them.

Most of them heard the term "displaced" for the first time. The problem in Khagrachari was that the research assistant, Kabita Chakma, was once the president of Hill Women's Federation and was directly involved in politics. In Panchari, there is an internal conflict between the Janashanghati Shamiti and United people's Democratic Front, which made it a little difficult for her to go there. The distance and remoteness of Rangamati was another problem. For example, it became quite tough to travel to the Doshor area of Rangamati due to the checking of the army and the BDR. Doshor was a very remote place where the research assistant had to travel by boat through the Kaptai Lake. Mechanised boats were not that available and to ensure the journey reservation was necessary. The same is true of the Ballalchara area. Both these places are included in the reserve forest area. However, the research assistant got help of 
the secretary of Doshar Market Committee and ward member. The headman of Ballalchara, Trun Kanti Tonchanga, helped in Bilaichari.

The participants of FGD were selected from among the respondents. The FGDs were carried out during the afternoon or evening. The discussion was carried out among 7-10 people. The discussion took place sometimes in the courtyard and sometimes in the market. Availability, especially of the male respondents, was a problem. In all the cases, people other than the respondents also took part in the discussion. Often the help of the local headman or the commissioner was needed.

Many NGOs like BRAC, ASA and Proshika are working in Khagrachari. Other small local NGOs also work here. The people who live in the Dighinala residential school building get ration from the government. In Doshar, Rangamati, Unicef and the Government of Bangladesh are carrying out some work on sanitation and health. There was no NGO activity in the slum areas of Khulna. Nijera Kori runs some motivation and awareness programmes in the Shathikunia and Mohammadnagar areas. In this programme there is no chance of monetary help. So, the IDPs are now attracted towards the micro-credit programmes.

Since shrimp cultivation is mainly done in the costal areas of Khulna, most of the developmental IDPs were from this region. Shrimp is one of the major export products of Bangladesh. According to experts, shrimp cultivation in Bangladesh started in 1929-30 in the Sundarbon area. It was done in the low lands along the banks of rivers before the implementation of the costal embankment project in the 1950s. Later, the project created stagnanation in the low lands, which created difficulty for cultivation of crops. From then on, these areas belonged to shrimp ghers (farms). In the late 1970, the demand for shrimp increased in the international market. So, the practice of using lands for shrimp cultivation extended to Shatkhira, Khulna and Bagerhat districts. Eventually, agricultural lands were being used as shrimp farms. The rate of extension of lands being used for shrimp farms was 16.6 per cent between 1982-83 and 1988-89. According to a calculation of UNDP and FAO, it was estimated that by the year 2005, 1, 29,530 acres of land would come into the purview of shrimp cultivation. But in reality, 1, 38,000 acres of land was being used for shrimp cultivation by 1994-95. This rapid growth rate of lands being used for shrimp cultivation increased the percentage of IDPs in this area. Because there is a rule in these areas that if an owner owing 85 per cent land of an area agrees to lease his land for shrimp cultivation, the owners of the other 15 per cent lands are bound to lease their lands, too. Otherwise, the person who is taking the lease can flood the whole area with salt water. Most of the owners of these shrimp farms are outsiders and influential businessman. They maintain good relation with the local influential people and the administration. They influence the local administration and with the help of local terrorists, overpower the landowners and establish shrimp farms. All these factors play a role in creating internally displaced people. The small peasants or day labourers lose their land and they have to leave the area in pursuit of work. Moreover, a lesser workforce is needed in the shrimp farms than in the agricultural field. So, the excess labourers become IDPs and come to the city. The same has happened to Paikgacha of Khulna. The people who used to live here now live in slums of Batiaghata of the same district. These slums are not permanent. They shift from one slum to another, from one profession to the next. Some of them have become industrial labourers and rickshaw pullers. Two FGDs were carried out in such a slum with two groups, one male and the other female.

The first important thing that comes into focus is that many of them became IDPs in the first place due to river erosion. There is an interrelationship between shrimp cultivation and river erosion. As the southern area of Khulna is included in the polder, the water flow here is regulated by sluice gates. The owners of the shrimp farms create sluice gates by cutting the WAPDA (Water and Power Development Authority) dam according to their own need. These gates are of lower quality than those build by WAPDA. So, sometimes these gates break down during high tide and cause flooding inside the polder. In the FGD it was told that in 1989-90, the entire polder No. 32 was flooded in Dakop Upojila. In that season, not a 
single farmer of Kumarkhola or Sutarkhali union was able to grow paddy. That is the first time when a lot of people became displaced in this area. At first these displaced people bought lands in other areas and restarted life there. They were hopeful that some day maybe a new land (char) would rise in the eroded area and they would get their land back. With this hope these people started living in the Kumkhali area of Paikgacha, which was nearby. Then shrimp cultivation started in this area, too. These marginalised farmers could not cultivate shrimp due to the lack of land or capital. As a result, they had to sell their habitat or the small amount of land they owned, and their ultimate destination was the city. After that, they are living an insecure life. They have not been able to establish any permanent way of income or residence.

Habibur Rahman of Batiaghata narrated almost the same story. He came from village Kumkhali of Paikgacha. He was a successful seasonal farmer in Kumkhali before shrimp cultivation started there. After it began in Kumkhali he lost his means of earning livelihood one by one as cultivation of any kind of crop became impossible. So he had to come to Khulna. He got a job in a medical clinic named Nirala. His wages were not enough to meet all the needs of his family, so poverty is his constant companion now. All the IDPs suffer the same turmoil in maintaining their family life. It also becomes very difficult to continue education of their children, not to mention the constant mental pressure that they have to sustain. These IDPs live in the suburbs, so they are able to send their children to the government primary school. But they cannot continue their education up to the secondary or higher secondary level due to poverty.

They have not got any help after becoming IDPs. They don't have any documents regarding this, nor have they needed those. In the slum areas, water supply and drainage system are a grave problem. They don't have any hope right now of going back to their original state. Many of them have sold their original habitat or have left it to their near relatives. In case of land, they have either leased it or sold it. NGOs work in Batiaghata, so the IDPs get credits and loans from them. As they have been living here for quite a long time (8-10 years), they don't recognise themselves as displaced anymore, they have become part of the local population. Discrimination against IDPs in Khulna is not very discrete as there are no racial or religious differences working here. The difference that is clear is the class difference. In case of economic standard, the IDPs are marginalised. As the IDPs live in slum areas, they are almost always deprived of their civic rights. They have to use common toilets. The political parties, both ruling and Opposition, ask them to attend their meetings according to their own need. They have to go there in the hope of getting something. People like Khodam Ali, Bojlu and Nur Ali have no work at the villages. So they cannot go back even if they want to. They hope that the government will take steps to solve this problem. They don't rely on the NGOs.

In the FGD of women, they expressed their agony of living in a single room in the slum after coming from the exuberant plenty of villages. They stated that they have lost their normal way of life. As there are more cases of kidnapping in the urban area, the mothers are always worried about their children. Amin's mothe $r$ thinks that as they lack a permanent address, nobody can rely on them enough to help. But as the government hospital is nearby the pregnant mothers get health facilities. The water supply and sanitation system, as mentioned before, is very inappropriate in the slums. So going to the toilet becomes a nuisance for the women. As it is a public toilet, they have to wait for a long time. They have never needed any document while shifting from one place to another. They want to go back to their original habitat but it is not possible as long as the shrimp farms are there. They don't know when again they will be able to cultivate their own lands. This is an uncertain future.

Many of them have sold their original habitat and associated lands, while others have just left it. But people having cattle or poultry have sold them before shifting. As they have moved upon their own decision, they had enough time to arrange things, so they have brought with them necessary furniture. While discussing about discrimination they said that women were discriminated everywhere. They don't face any particular discrimination for being IDPs. Their life in the slums is different from their village 
life. They have lost their habitat mainly due to the shrimp farms, and the administration has only made things worse for them. Now they are living an inhuman life.

Internal displacement in the Chittagong Hill Tracts occurred during the armed conflict from the mid1970s to 1997. The violent conflict in the Chittagong Hill Tracts between the 13 different ethnic groups and the Bengalis of the plains has been the root cause of one of the largest occurrences of internal displacement in Bangladesh. This spanned over three decades until an accord was reached between the Jana Sanghati Samiti (JSS), demanding autonomy of the jumma (slash and burn cultivators) and the Bangladesh government in 1997. A Government Task Force estimated that as of July 2000, 128,000 families were internally displaced in this region. The three decades of forced evictions, terrorisation as part of counter-insurgency techniques and planned settlements of plains Bengalis in the CHT have caused havoc in the life of people who refused to flee to India. After the accord many refugees have come back to find their land taken away and occupied by Bengali settlers and military. They now join the ranks of the internally displaced.

In total six FGDs were held in the CHT. Women's groups and male groups were done separately. Research assistants carried out these FGDs mainly on the basis of availability. Discussions of the women's group were carried out in the East Narankhaiya village of Khagrachari. The participants stated that they had been displaced several times. At first it was in 1960 when they were displaced due to the building of Kaptai Dam in Rangamati. Then they built their habitat in Larmapara, Narankhaiya and Logang areas of Khagrachari. Then they were displaced due the mass killings in Panchari and Logang. At that time many of them crossed the border and went to the neighbouring country of India. This was the incident of 1986-89. Then, after the peace treaty in 1997, they changed their habitat back to Bangladesh and built their homes in the present location.

They have identified different reasons for their displacement. Conflict between the army and the Shantibahini, mass killing, order of the army to leave the place, collaboration of the Bengali settlers with the army in dispossessing them of their houses, etc., are some of the reasons. The movement of the indigenous hill people to establish their identity and rights and the oppression of the army have created an unstable situation in the CHT. Armed conflicts are at large here. The indigenous people keep moving from one place to another to protect their existence. Some of them left the country and became refugees in India. Most of them have built new habitats inside the CHT.

The main problem of being displaced was the problem of residence. When they left they had nothing to take with them as either it was burnt or they were too afraid for their lives to take anything. They had to face problems with employment, education, food, security and mental stress. Those who were displaced due to the Logang mass killing underwent a lot of stress. They were always apprehensive whether Bengalis would come again to kill them. As the night fell, they felt that death was roaming around them. Those who became refugees had to live a terrible life. They had to depend only on the ration as they had no employment.

While talking about the help they got, they stated that government had never offered them any help and their voices were ignored. But their relatives and the civil society helped them. The IDPs had no documents when they were roaming from one place to another. They were only trying to survive then. Even when they were refugee in India, they had no documents. When they returned a government list was made. Only those whose names were mentioned there were able to come back.

The hill women had to face most problems after being displaced. Their movements were restricted in fear of the army. Their education also suffered as they were displaced by giving a short notice. They had to face problems of water supply and sanitation. Malaria, other fevers and diarrhoea have become more prevalent among them. IDPS are more interested now to return to their original habitat. Even now they 
dream of their lands, their homesteads that is under the water of Kaptai dam. They want to return to normal life where there is assurance of food, security, education and residence.

In Bangladesh, most IDP families had an annual income between Rs 1000 and Rs 3000. About 42 per cent of the respondents were displaced due to development project and 51 per cent due to armed conflict and army occupation. More than 80 per cent reported that they had been displaced more than once. Only 53 per cent received any form of material support, of whom only 26 per cent received support from the government. About 23 per cent received support from non-governmental sources. About 59 per cent of all respondents stated that they were in poor health condition. The government health centres provided service to over 50 per cent of the respondents. Over 68 per cent reported that no support was forthcoming for either pregnant women or the elderly. 29 per cent reported that they faced social discrimination and 58 per cent marked economic problems as their main problem for survival. The overwhelming number (82 per cent) of IDPs reported that they had no possibility of return. 97 per cent of the IDPs reported that they have no knowledge of the Guiding Principles. None of the government representatives spoke to them of any policy mechanisms available for them and only 3 per cent reported that they got some information about the same from the media. More than 74 per cent had suggestions for these agencies responsible for rehabilitation of IDPs. About the recommendations made, 27 per cent said that displacement needed to be contained through policy measures and 22 per cent said more social and economic assistance was required. Only 9 per cent sought appropriate compensation and 3 per cent wanted the facilitation of early return. This is not because they did not want to but they realised the impossibility of that demand. IDPs who had been displaced for a long time have lost almost all hopes of return. This is particularly true of Bangladesh as most of their lands were handed over to another group of people.

\section{FREQUENCY TABLES}

\subsection{Household Head}

\begin{tabular}{|l|c|c|}
\hline & No. of Respondents & Percentage \\
\hline Yes & 52 & 52.0 \\
\hline No & 48 & 48.0 \\
\hline Total & 100 & 100.0 \\
\hline
\end{tabular}

\subsection{Age}

\begin{tabular}{|l|c|c|}
\hline & No. of Respondents & Percentage \\
\hline 14-24 Yrs. & 7 & 7.0 \\
\hline 25-39 Yrs. & 37 & 37.0 \\
\hline 40-59 Yrs. & 39 & 39.0 \\
\hline $60 \&$ above & 17 & 17.0 \\
\hline Total & 100 & 100.0 \\
\hline
\end{tabular}




\subsection{Gender Status}

\begin{tabular}{|l|c|c|}
\hline & No. of Respondents & Percentage \\
\hline Female & 51 & 51.0 \\
\hline Male & 49 & 49.0 \\
\hline Others & 0 & 0.0 \\
\hline Total & 100 & 100.0 \\
\hline
\end{tabular}

\subsection{Literacy Level}

\begin{tabular}{|l|c|c|}
\hline & No. of Respondents & Percentage \\
\hline Illiterate & 40 & 40.0 \\
\hline Can only read & 6 & 6.0 \\
\hline Read and write both & 17 & 17.0 \\
\hline Till primary & 17 & 17.0 \\
\hline Till high school & 13 & 13.0 \\
\hline Above school & 7 & 0.0 \\
\hline No comment & 0 & 100.0 \\
\hline Total & 100 & \\
\hline
\end{tabular}

\subsection{Marital Status}

\begin{tabular}{|l|c|c|}
\hline & No. of Respondents & Percentage \\
\hline Married & 90 & 90.0 \\
\hline Unmarried & 5 & 5.0 \\
\hline Divorced / Separated & 3 & 3.0 \\
\hline Widow / Widower & 2 & 2.0 \\
\hline Total & 100 & 100.0 \\
\hline
\end{tabular}




\subsection{Family Members}

\begin{tabular}{|l|c|c|}
\hline & No. of Respondents & Percentage \\
\hline Below 5 & 30 & 30.0 \\
\hline Between 5-8 & 57 & 57.0 \\
\hline Above 8 & 13 & 13.0 \\
\hline Total & 100 & 100.0 \\
\hline
\end{tabular}

\subsection{Adult Members in Family}

\begin{tabular}{|l|c|c|}
\hline & No. of Respondents & Percentage \\
\hline Below 2 & 2 & 2.0 \\
\hline Between 2-5 & 81 & 81.0 \\
\hline Above 5 & 17 & 17.0 \\
\hline Total & 100 & 100.0 \\
\hline
\end{tabular}

\subsection{Number Children in Family}

\begin{tabular}{|l|c|c|}
\hline & No. of Respondents & Percentage \\
\hline Below 2 & 21 & 21.0 \\
\hline Between 2-5 & 64 & 64.0 \\
\hline Above 5 & 1 & 1.0 \\
\hline Not applicable & 14 & 14.0 \\
\hline Total & 100 & 100.0 \\
\hline
\end{tabular}




\subsection{Current Occupation}

\begin{tabular}{|l|c|c|}
\hline & No. of Respondents & Percentage \\
\hline Domestic / Agricultural Labour & 31 & 31.0 \\
\hline Industrial Labour & 18 & 18.0 \\
\hline Self Trade & 4 & 4.0 \\
\hline Others & 47 & 47.0 \\
\hline Multiple answers & 0 & 0.0 \\
\hline No comment & 0 & 0.0 \\
\hline Total & 100 & 100.0 \\
\hline
\end{tabular}

\subsection{Current Monthly Income}

\begin{tabular}{|l|c|c|}
\hline & No. of Respondents & Percentage \\
\hline No Income & 1 & 1.0 \\
\hline Below Rs. 1000 & 33 & 33.0 \\
\hline $\begin{array}{l}\text { Between Rs. } \\
\text { 1000-2000 Rs. }\end{array}$ & 25 & 25.0 \\
\hline $\begin{array}{l}\text { Between 2000-3000 } \\
\text { Above Rs. 3000 }\end{array}$ & 9 & 32.0 \\
\hline No comment & 0 & 0.0 \\
\hline Total & 100 & 100.0 \\
\hline
\end{tabular}

\subsection{Displacement Reasons}

\begin{tabular}{|l|c|c|}
\hline & No. of Respondents & Percentage \\
\hline Natural Disaster & 3 & 3.0 \\
\hline Development Project & 42 & 42.0 \\
\hline Armed Conflict & 30 & 30.0 \\
\hline Army Occupation & 21 & 21.0 \\
\hline
\end{tabular}




\begin{tabular}{|l|c|c|}
\hline Others & 4 & 4.0 \\
\hline Multiple answers & 0 & 0.0 \\
\hline No comment & 0 & 0.0 \\
\hline Total & 100 & 100.0 \\
\hline
\end{tabular}

\subsection{Years in Displacement Situation}

\begin{tabular}{|l|c|c|}
\hline & No. of Respondents & Percentage \\
\hline One year or less & 1 & 1.0 \\
\hline Between 1-3 Years & 19 & 19.0 \\
\hline Between 3-5 Years & 19 & 19.0 \\
\hline Above 5 Years & 61 & 61.0 \\
\hline No comment & 0 & 0.0 \\
\hline Total & 100 & 100.0 \\
\hline
\end{tabular}

\subsection{Directly journeyed from Original to Current Place}

\begin{tabular}{|l|c|c|}
\hline & No. of respondents & Percentage \\
\hline Yes & 17 & 17.0 \\
\hline No & 83 & 83.0 \\
\hline No comment & 0 & 0.0 \\
\hline Total & 100 & 100.0 \\
\hline
\end{tabular}

\subsection{Single / Multiple Displacement}

\begin{tabular}{|l|c|c|}
\hline & No. of Respondents & Percentage \\
\hline More than once & 80 & 80.0 \\
\hline No & 20 & 20.0 \\
\hline No comment & 0 & 0.0 \\
\hline
\end{tabular}




\begin{tabular}{|l|c|c|}
\hline Total & 100 & 100.0 \\
\hline
\end{tabular}

\subsection{Material Support Available}

\begin{tabular}{|l|c|c|}
\hline & No. of Respondents & Percentage \\
\hline Yes & 53 & 53.0 \\
\hline No & 47 & 47.0 \\
\hline No comment & 0 & 0.0 \\
\hline Total & 100 & 100.0 \\
\hline
\end{tabular}

\subsection{Support Provider}

\begin{tabular}{|l|c|c|}
\hline & No. of Respondents & Percentage \\
\hline Government & 26 & 26.0 \\
\hline NGO/INGO & 23 & 23.0 \\
\hline Others & 0 & 0.0 \\
\hline Multiple answers & 5 & 5.0 \\
\hline No comment & 0 & 0.0 \\
\hline Not applicable & 46 & 46.0 \\
\hline Total & 100 & 100.0 \\
\hline
\end{tabular}

\subsection{Type of Support}

\begin{tabular}{|l|c|c|}
\hline & No. of Respondents & Percentage \\
\hline Economic Support & 23 & 23.0 \\
\hline Shelter & 6 & 6.0 \\
\hline Food & 7 & 7.0 \\
\hline Education & 0 & 0.0 \\
\hline Health & 1 & 1.0 \\
\hline
\end{tabular}




\begin{tabular}{|l|c|c|}
\hline Psychological & 0 & 0.0 \\
\hline Repatriation related & 0 & 0.0 \\
\hline Others & 0 & 0.0 \\
\hline Multiple support & 18 & 18.0 \\
\hline Not applicable & 45 & 45.0 \\
\hline Total & 100 & 100.0 \\
\hline
\end{tabular}

\subsection{Educational Support for Children}

\begin{tabular}{|l|c|c|}
\hline & No. of Respondents & Percentage \\
\hline Yes & 44 & 44.0 \\
\hline No & 56 & 56.0 \\
\hline Not applicable & 0 & 0.0 \\
\hline Total & 100 & 100.0 \\
\hline
\end{tabular}

\subsection{Do Children Work Anywhere?}

\begin{tabular}{|l|c|c|}
\hline & No. of Respondents & Percentage \\
\hline Yes & 33 & 33.0 \\
\hline No & 64 & 64.0 \\
\hline Not applicable & 3 & 3.0 \\
\hline Total & 100 & 100.0 \\
\hline
\end{tabular}

\subsection{Job Nature of Children}

\begin{tabular}{|l|c|c|}
\hline & No. of Respondents & Percentage \\
\hline Domestic Labour & 9 & 9.0 \\
\hline Industrial Labour & 16 & 16.0 \\
\hline Others & 7 & 7.0 \\
\hline
\end{tabular}




\begin{tabular}{|l|c|c|}
\hline Not applicable & 68 & 68.0 \\
\hline Total & 100 & 100.0 \\
\hline
\end{tabular}

\subsection{Health Condition of Family Members}

\begin{tabular}{|l|c|c|}
\hline & No. of Respondents & Percentage \\
\hline Good & 37 & 37.0 \\
\hline Better & 4 & 4.0 \\
\hline Poor & 59 & 59.0 \\
\hline No comment & 0 & 0.0 \\
\hline Not applicable & 0 & 0.0 \\
\hline Total & 100 & 100.0 \\
\hline
\end{tabular}

\subsection{Medical Assistance in Need}

\begin{tabular}{|l|c|c|}
\hline & No. of Respondents & Percentage \\
\hline $\begin{array}{l}\text { Govt. Health } \\
\text { Centre }\end{array}$ & 48 & 48.0 \\
\hline Private Clinic & 14 & 14.0 \\
\hline Ayurvedic Doctor & 2 & 2.0 \\
\hline $\begin{array}{l}\text { NGO Supported } \\
\text { Clinic }\end{array}$ & 0 & 0.0 \\
\hline Others & 1 & 34.0 \\
\hline Multiple answers & 34 & 0.0 \\
\hline No comment & 0 & 1.0 \\
\hline Not applicable & 1 & 100.0 \\
\hline Total & 100 & \\
\hline
\end{tabular}




\subsection{Recruitment of Children in Armed Forces}

\begin{tabular}{|l|c|c|}
\hline & No. of Respondents & Percentage \\
\hline Yes & 3 & 3.0 \\
\hline No & 60 & 60.0 \\
\hline Not applicable & 37 & 37.0 \\
\hline Total & 100 & 100.0 \\
\hline
\end{tabular}

\subsection{Support to Pregnant / Elderly}

\begin{tabular}{|l|c|c|}
\hline & No. of Respondents & Percentage \\
\hline Yes & 31 & 31.0 \\
\hline No & 68 & 68.0 \\
\hline No comment & 0 & 0.0 \\
\hline Not applicable & 1 & 1.0 \\
\hline Total & 100 & 100.0 \\
\hline
\end{tabular}

\subsection{Major Concern of Pregnant / Elderly}

\begin{tabular}{|l|c|c|}
\hline & No. of Respondents & Percentage \\
\hline No allowance & 15 & 15.0 \\
\hline Lack of security & 5 & 5.0 \\
\hline Lack of basic amenities & 8 & 8.0 \\
\hline Others & 0 & 0.0 \\
\hline Multiple concern & 3 & 3.0 \\
\hline No comment & 0 & 0.0 \\
\hline Not applicable & 69 & 69.0 \\
\hline Total & 100 & 100.0 \\
\hline
\end{tabular}


2.26 Problems Faces in the Region

\begin{tabular}{|l|c|c|}
\hline & No. of Respondents & Percentage \\
\hline Social Discrimination & 29 & 29.0 \\
\hline Economic Problems & 58 & 58.0 \\
\hline Lack of Security & 3 & 3.0 \\
\hline Others & 0 & 0.0 \\
\hline Multiple answers & 10 & 10.0 \\
\hline No comment & 0 & 0.0 \\
\hline Total & 100 & 100.0 \\
\hline
\end{tabular}

\subsection{Restriction in Movement}

\begin{tabular}{|l|c|c|}
\hline & No. of Respondents & Percentage \\
\hline Yes & 21 & 21.0 \\
\hline No & 79 & 79.0 \\
\hline No comment & 0 & 0.0 \\
\hline Total & 100 & 100.0 \\
\hline
\end{tabular}

\subsection{Probability of Return}

\begin{tabular}{|l|c|c|}
\hline & No. of Respondents & Percentage \\
\hline Yes & 18 & 18.0 \\
\hline No & 82 & 82.0 \\
\hline No comment & 0 & 0.0 \\
\hline Total & 100 & 100.0 \\
\hline
\end{tabular}


2.29 Agency Responsible For Return

\begin{tabular}{|l|c|c|}
\hline & No. of Respondents & Percentage \\
\hline Government & 12 & 12.0 \\
\hline NGO/INGO & 0 & 0.0 \\
\hline Others & 8 & 8.0 \\
\hline Multiple answers & 0 & 0.0 \\
\hline No comment & 0 & 0.0 \\
\hline Not applicable & 80 & 0.0 \\
\hline Total & 100 & 100.0 \\
\hline
\end{tabular}

\subsection{Reasons For No Possibility of Return}

\begin{tabular}{|l|c|c|}
\hline & No. of Respondents & Percentage \\
\hline Socio -Political & 19 & 19.0 \\
\hline $\begin{array}{l}\text { Loss of } \\
\text { Livelihood }\end{array}$ & 36 & 36.0 \\
\hline Lack of security & 23 & 23.0 \\
\hline Others & 2 & 2.0 \\
\hline Multiple answers & 0 & 0.0 \\
\hline No comment & 0 & 20 \\
\hline Not applicable & 20 & 100.0 \\
\hline Total & 100 & \\
\hline
\end{tabular}

\subsection{Knowledge of Policy Mechanisms for IDPs}

\begin{tabular}{|l|c|c|}
\hline & No. of Respondents & Percentage \\
\hline Multiple answer & 5 & 5.0 \\
\hline Local (Yes) & 2 & 2.0 \\
\hline Local (No) & 93 & 93.0 \\
\hline
\end{tabular}




\begin{tabular}{|l|c|c|}
\hline Total & 100 & 100.0 \\
\hline
\end{tabular}

\subsection{Nature of Policy Mechanisms}

\begin{tabular}{|l|c|c|}
\hline & No. of Respondents & Percentage \\
\hline Law / Act & 1 & 1.0 \\
\hline Official Documents & 0 & 0.0 \\
\hline Media & 6 & 6.0 \\
\hline Others & 0 & 0.0 \\
\hline Multiple answers & 0 & 0.0 \\
\hline No comment & 0 & 0.0 \\
\hline Not applicable & 93 & 93.0 \\
\hline Total & 100 & 100.0 \\
\hline
\end{tabular}

\subsection{Knowledge of UN Guiding Principles}

\begin{tabular}{|l|c|c|}
\hline & No. of Respondents & Percentage \\
\hline Yes & 3 & 3.0 \\
\hline No & 97 & 97.0 \\
\hline No comment & 0 & 0.0 \\
\hline Not applicable & 0 & 0.0 \\
\hline Total & 100 & 100.0 \\
\hline
\end{tabular}

\subsection{Source of Knowledge About Policy Mechanisms}

\begin{tabular}{|l|c|c|}
\hline & No. of Respondents & Percentage \\
\hline Government representative & 0 & 0.0 \\
\hline NGO worker & 1 & 1.0 \\
\hline Friends & 0 & 0.0 \\
\hline
\end{tabular}




\begin{tabular}{|l|c|c|}
\hline Media & 3 & 3.0 \\
\hline Others & 0 & 0.0 \\
\hline No answers & 0 & 0.0 \\
\hline No comment & 0 & 0.0 \\
\hline Not applicable & 96 & 96.0 \\
\hline Total & 100 & 100.0 \\
\hline
\end{tabular}

\subsection{Improvement in Condition Due to Policy Mechanisms}

\begin{tabular}{|l|c|c|}
\hline & No. of Respondents & Percentage \\
\hline Yes & 2 & 2.0 \\
\hline No & 9 & 9.0 \\
\hline No comment & 0 & 0.0 \\
\hline Not applicable & 89 & 89 \\
\hline Total & 100 & 100.0 \\
\hline
\end{tabular}

\subsection{Any Suggestions To Agencies For IDPs Rehabilitation}

\begin{tabular}{|l|c|c|}
\hline & No. of Respondents & Percentage \\
\hline Yes & 74 & 74.0 \\
\hline No & 14 & 14.0 \\
\hline No comment & 12 & 12.0 \\
\hline Total & 100 & 100.0 \\
\hline
\end{tabular}

\subsection{Nature of Suggestions to Agencies}

\begin{tabular}{|l|c|c|}
\hline & No. of Respondents & Percentage \\
\hline Stop displacement at source & 12 & 12.0 \\
\hline Contain displacement through policy measures & 27 & 27.0 \\
\hline
\end{tabular}




\begin{tabular}{|l|c|c|}
\hline More social and economic assistance to be provided & 22 & 22.0 \\
\hline More security and care to be provided & 1 & 1.0 \\
\hline Appropriate compensation to be provided & 9 & 9.0 \\
\hline Steps towards early return of the IDPs & 3 & 3.0 \\
\hline Others & 0 & 0.0 \\
\hline Multiple answers & 0 & 0.0 \\
\hline No comment & 14 & 14.0 \\
\hline Not applicable & 12 & 100.0 \\
\hline Total & 100 & \\
\hline
\end{tabular}




\section{Nepal}

'Maoists had forced us to move by blaming us of being "government agents". They tortured us and looted our properties. In this situation, government did not give any compensation and sympathy. Isn't it the government's responsibility to provide us security and support?" - Parelal Baniya, Mugu district, Nepal

In Nepal the king is not merely a figurehead. He is the de facto head of state. Till recently, the Emergency powers rested with him and he could dissolve any government that he desired. Since 1996, the Communist Party of Nepal - Maoists (CPN-M) launched a campaign to bring back power to the people. This led to a violent conflict between the CPN-M on the one hand and the government and the King on the other, resulting in large-scale displacement in Nepal. The conflict witnessed the breakdown of the education system, closure of business ventures, weakening of local economies and disruption of public services. People were evicted from the countryside either by Maoists or security forces. These people migrated to Nepalgunj, Pokhara, Dhangadi and Biratnagar. Those who had resources moved to the capital city of Kathmandu.

The national action plan of human rights mentions that in the seven years of conflict, of which the last three years witnessed particularly violent fighting between the Maoists and the security forces, many lives were lost including those of civilians, security personnel, and the Maoists. Thousands were displaced. This study was designed to assess the human rights situation of internally displaced persons in Nepalgunj where the condition of IDPs is potentially severe. Taking into account the resource limitations, the study was limited to a purposive sample size of 100 households in three clusters. Attention was paid to maintain balance in terms of gender, ethnicity (like Dalits) and disadvantaged groups affected by the conflict. Thus, the findings of the study cannot be considered representative of the entire conflict-induced IDP population in Nepal.

The study focused on identifying the needs and aspirations of the IDPs, their access to humanitarian assistance, neglected areas of the humanitarian assistance, their access to education, health, shelter, freedom of movement and other fundamental rights, as well as the state' s efforts addressing relief, rehabilitation, resettlement or reintegration and protection issues. In this study, 119 respondents were selected for interview in which 57 were from the Rajana Camp (IDP Settlement Area) whereas 62 were from outside the camp, residing in various locations of Bardiya district. The IDPs in Nepal are suffering from inadequate resources and the lack of shelter, education and health facilities. The Representative of the UN Secretary General for Human Rights of IDPs mentioned in his mission report that the problems that the IDPs faced were related to poor security and protection, inadequate food, shelter and access to healthcare, lack of schools for children, lack of identification documents, widespread gender-based violence, sexual abuse and domestic violence, increase in child labour, prostitution and loss of rights such as voting rights by the IDPs.

The quantitative findings reveal that there are severe consequences of displacement. Most IDPs living in the cities suffer from the scourge of unemployment. More than two-fifth of the respondents (41 per cent) stated that they were unemployed while over 39 per cent were involved in domestic or agriculture labour, fishing and dairy works. About 17 per cent of the respondents were involved in trade (shop keeping, vending, etc.) and a negligible proportion - only 3 per cent - were engaged in industrial sector (mechanical labour, security guards, etc.). The vast majority of the respondents (68 per cent) had less than Rs 1,000 monthly earning per family. The IDPs face difficulties in getting employment because of their lack of skills and adequate capacity to look for jobs. As a result there is an exodus of young people to India and elsewhere for jobs. Many IDPs are employed in menial jobs. These jobs have very low wages and it is extremely difficult for people to survive on them. 
More than three-fourth of the respondents stated that their health condition was very poor due to lack of affordable healthcare facilities at their access. The vast majority of the respondents (62 per cent) relied on the government hospitals and health posts for their medical treatment. NGO- supported clinics provide health facilities to eight per cent of the population and another eight per cent care for their health themselves. Most pregnant women or the elderly received no special attention and of the 54 cases heard during the course of this research, only two had received special care because of either being pregnant or being elderly.

Nearly three-fourth (73 per cent) of the respondents were displaced due to their affiliation to political parties - the Maoists threatened and took hostage the cadres of political parties, etc. Another important reason for displacement found in this study was poverty (15 per cent). About six per cent of the respondents were displaced due to natural disaster and about 2 per cent were displaced due to development projects. More than 4 per cent were displaced because their family members were serving in the army or police force. Girls and women are largely displaced due to death of their husbands and constant threats from the Maoists. The widows also have to bear responsibility of looking after their children and elderly family members. There is no regular income for the widows. On the other hand, many girls are forced to work in restaurants in urban areas. There is continuous harassment and abuse that they have to face. There is no personal safety and security.

Nearly two-third of the respondents (66 per cent) directly came from the place of origin and over onethird (34 per cent) had undergone multiple displacements. Although the conflict in Nepal is fairly recent compared to other conflicts in South Asia, people are living as IDPs for a fairly long time. One-fourth of the IDPs interviewed were displaced between four and five years. About 18 per cent left their homes more than five years ago. But the highest percentage (over 40 per cent) of those displaced have lived as IDPs for one to three years.

Only 35 per cent of the respondents said that they received some support. The remaining respondents clearly stated that they were yet to receive any type of support. Of these respondents, 55 per cent received support from the NGO/INGOs and the remaining (45 per cent) said that they had support from governmental organisations. The respondents who had got support were further asked what type of support they had received. Most of them got multiple supports. Of those who received support from various agencies, 86 per cent got shelter, 79 per cent food and 64 per cent economic support. One-third of them were provided with educational support, 29 per cent got health support, 5 per cent got psychological support and 2 per cent obtained repatriation-related support. If we analyse according to the number of responses, the highest proportion of the respondents (29 per cent) got support for their shelter, followed by food support ( 26 per cent), economic support ( 22 per cent), educational support ( 11 per cent) and health support (10 per cent). The lowest proportion of the respondents ( 1 per cent) got repatriation-related support, followed by psychological support (2 per cent).

The situation is further aggravated as the humanitarian agencies are facing problems in providing assistance to the IDPs in Nepal. The main obstacles for the international relief agencies to support the IDPs are the lack of an accurate picture or estimate of their number. Few relief agencies, like World Food Programme (WFP) and the Red Cross are helping to provide basic relief like food and clothes for displaced families sheltered in the camps in Nepalganj and Surkhet in west Nepal where the largest numbers of IDPs live. A report by the Norwegian Refugee Council in 2004 had sharply criticised international relief organisations for not providing adequate support to IDPs in Nepal ${ }^{4}$. However, this is partially true because of destruction of physical infrastructures like communication, roads, bridges and power plants by the rebels.

1. Nepali Times, 1 July 2005, reported by Naresh Newar, http://www.nepalitimes.com/issue243/nation.htm 
In terms of knowledge regarding support mechanisms, 44 per cent stated that they had knowledge of international support mechanisms. Of the total number of IDPs interviewed about one-fourth responded that they had heard of the Guiding Principles on Internal Displacement. In cross tabulation it was found out that 15 per cent of those who did not know how to read and write knew about the GP and only 11 per cent of the group that could read but not write knew of the GP. The highest numbers of respondents possessing knowledge of the GP were those who studied up to the primary level. Among the 29 respondents possessing knowledge of the GP, 22 were literate.

More than one-fourth of the respondents stated that they were frequently forced to get their children recruited in the armed forces. This problem is further exacerbated because there are no proper schools or educational facilities for children. Some children may have been forced to leave their schools in the middle of the academic year and even those who can afford to enter new schools are not taken in because they are in the middle of an academic year. Clearly, their rights to access education is denied because of this problem although sometimes some private schools may take them in. Most often government schools are in no position to enrol students who have been displaced because of their limited infrastructure and lack of teachers.

Regarding knowledge of support mechanisms available for IDPs, of the respondents who knew about these mechanisms, more than one-fifth (29 per cent) knew about the local mechanisms, two-fifth of international mechanisms and only 12 per cent of the total respondents knew about the national mechanisms regarding IDP issues. Knowledge of the UN Guiding Principles on internally displaced persons was found among 24 per cent of the respondents. Most of the respondents got information about UN Guiding Principles through media (newspaper reports, radio, TV, etc.) and NGO workers. Respondents who had knowledge of at least one mechanism mentioned above were further asked whether those mechanisms were helpful to improve IDPs' condition. Only one person out of 74 who had knowledge about at least one of the mechanisms, said that the mechanisms were helpful to improve the IDPs' condition, whereas the remaining 73 stated that those mechanisms did not help to improve their condition.

More than one-third (35 per cent) of the respondents stated that they had problems in moving from one place to another in the residing area. The vast majority (63 per cent) of the respondents stated that there was no possibility of returning to their homes while slightly over one-fourth ( 26 per cent) stated that there was still probability in the process. Of those respondents who were hopeful of returning to their homes, the vast majority ( 87 per cent) held that the government should initiate the process. The respondents who felt it was impossible to return to their homes were further asked the reasons behind their assertions. The majority of them expressed said it was due to lack of security. In the survey, respondents were asked what type of problems they were facing. Most of them stated more than one problem. Of those who had stated that there were some kind of problems, 61 per cent had economic / employment-related problems, 58 per cent had lack of security of their children, women and elderly members of the family, while 29 per cent had social discrimination/forcible integration problems.

Respondents were further asked whether they had any suggestion to the organisations that were involved in IDPs' concerns. Only 18 (15 per cent) came up with some suggestions whereas the vast majority (85 per cent) had no suggestion to those organisations. Respondents who had stated that they had suggestions to the organisations involved in IDPs' concerns were further asked about the type of suggestions. According to the result that is presented in table 33, most of the respondents had more than one suggestion. Out of those who offered suggestions, 67 per cent suggested providing them with appropriate compensation, 56 per cent suggested to building more sense of security and care, 39 per cent suggested stopping displacement at source, 39 per cent suggested controlling displacement through policy measures, 33 per cent suggested taking steps towards early return of the IDPs, and 28 per cent suggested providing more social and economic assistance. 
In addition, five focus-group discussions were held in the study area. The groups comprised men, women, children and the elderly and were mixed groups of men and women. Each group had 10 to 14 participants with the same characteristics. The discussions were focused particularly on reasons of leaving their ancestral place (where and when, why), problems (residence, employment, education, food, security and psychological stress) that they were facing, support mechanisms and types of support (government, nongovernment and civil society), travel documents (passport, citizenship and other documents), major problems faced by vulnerable groups (women, children, disabled and elderly people), family disintegration, food (nutrition), security, education, health (prenatal care, infectious diseases), water and sanitation, aspiration of the IDPs (return to home and look for normal life), use of property and possessions left behind in habitual place of residence (land, house, cattle and others), discrimination among the IDPs in terms of gender, caste/ethnicity, religion or belief, political or other affiliation, age, disability, etc., incitement (state party, non-state party and others), repatriation, etc. Findings of these discussions clearly indicate the vulnerable condition of each sub-group.

The discussion was held among 12 women displaced from Jumla district. The internally displaced women belonged to different villages of Kanaksunadari and Birat VDCs. The underlying reason for displacement of all of them was, obviously, the conflict. Some of them fled because their properties were seized. Others were threatened by Maoists either to join their party or to leave the village. They, therefore, ultimately decided to flee their villages and homes due to the fear of being abducted. Some households could not cope with the Maoists' threats to recruit their children in the latter's revolution. The displaced women face a range of problems. The major problems, as they said, were lack of food and shelter and employment. They lived in rented rooms, but could hardly afford to pay the rent. On top of it, discrimination and harassment were the other problems. Both of the spouses are unemployed, so sometimes they even collected firewood from nearby jungles to earn some money to buy their food. The problems were further compounded as they could not afford schools fees for their children. Illiteracy was the main reason resulting in unemployment. Their landlords harassed some of them while others did not have access to drinking water resources. Health problems due to very hot weather were also putting them in trouble. Women were bound to tolerate psychological trauma due to displacement-related complications, like killing of family members, abductions, and forceful eviction from their homes. Malnutrition among their children and the lack of capacity to afford health services were the other problems. Male counterparts of most of the IDP women were away from them. A large number of them went to India seeking jobs there. This further led to disharmony in the family and, at times, even the families were broken.

Twelve males from Jumla and Jajarkot districts were the participants of the male focus group discussion. According to them, the reason behind their displacement was primarily due to armed conflict in their districts. The hardest hit VDCs were Kanaksundaripur and Biratpur. Many of them were displaced after their houses were reduced to ashes by Maoists; and the reason: police rented their homes for office purpose. Some of them were displaced as they were unable to pay levy to the Maoists. Others were displaced as their family members were kidnapped and killed, houses got locked, property was seized. Many others also received life threats by Maoists, or had their sons killed; some of them were also threatened by either side. Displaced males were facing different kinds of problems such as lack of food, shelter and clothing. Due to the illiteracy and skills required for the employment, they could not catch the employment opportunities available. In addition to this, due to ideological differences, locals were reluctant to offer jobs to some of the IDPs. Psychological problem due to loss of properties and trauma resulting from security threat from Maoists was another major problem of displaced males of Kohalpur area of Bardiya district. Lack of schooling facilities for their children, poor health condition due to unhygienic food and water and inability to approach authorities to entertain IDPs' rights were some other problems faced by them. The IDPs perceived that NGOs and the civil society organisations have been receiving large-scale assistance from donor agencies to support them. However, they did not receive such support so far and thus smelled manipulation of budget for some other purposes. They had received some 
support in terms of cash, tents and foodstuff from some organisations. However, they did not get any support after June 2005.

The major problems faced by elderly IDPs were lack of food, adequate shelter, clothing and deteriorating health conditions. They could not find jobs because of their physical weakness, lack of skills required for the job compounded by prevailing illiteracy among them. In addition to these problems, poor eyesight, loss of hearing, other physical weaknesses, adjustment problems in the urban areas due to the differences in the life pattern they used to, were also the problems in the camps. Discrimination in the current settlement area by local habitants was also straining them. Some of them were suffering from depression problems as well. Many of them had stories to tell about how they spent days and nights only with "lukewarm water and a pinch of salt" as food. The elderly IDPs have not yet received any specific support to address their problems. From the government side, only a few relief materials were airdropped from their respective district headquarters to Nepalgunj by army helicopters. They could not go to the concerned authorities for the fulfillment of their demands related to basic needs because of the lack of money and physical weaknesses. Some NGOs had provided tarpaulin, utensils and foodstuff in the beginning; however, these supports were totally stopped from June 2005. The shelters of Rajana Camp (where most of the elderly IDPs have been residing), which are mostly made of local materials like straw, mud and bamboo, were not strong enough to protect them from rain and cold. The IDPs have been leading their life with no future prospects in the camp. They said that they were hard hit by food scarcity, lack of sufficient place to live in and lack of amenities for a basic living. The employment opportunities were almost non-existent. The IDPs expressed their concerns that most of them were illiterate and already old, therefore, it was beyond their capacity to earn their living. One of the most shocking aspects, as they opined, was lack of educational opportunities to their children due to their poor economic condition. The IDPs were undergoing frequent psychological problems as well. They reported that they often felt unwell and even fell sick due to psychological problems. Amidst difficulties, the FGD participants, however, were satisfied with the security situation in the camp. They pointed out security as one of the comparative advantages of being in the camp. They never experienced any threat from the parties involved in the conflict here.

The IDPs said that both the government and the civil societies neglected them. For quite a long time, they did not have access even to basic humanitarian assistance, despite the fact that it was their right. However, with a fresh ad-hoc decision of the District Development Committee to allow IDPs to settle at Kiran Nala (Rajana Camp), the settlement problems of IDPs were addressed to some extent. This is an ad-hoc decision after all; therefore, the IDPs still perceived a potential threat of losing their home in the same way, as they were forcibly made homeless.

Fourteen participants (seven males and seven females) from Dailekh, Mugu and Jumla districts had taken part in this group discussion. They were living in Rajana Base Camp, Kohalpur. Most of them were displaced from their villages three years ago. According to them, the Maoists forced them to leave their homes due to their refusal to join the "people's party". Likewise, others were displaced for the fear of abduction and pressure to join Maoists' outfit. Some paren ts strongly opposed the Maoists ' proposal to recruit their children in the "people's army" of the rebels. During the discussions, it was also revealed that the Maoists never respected those who had ideological differences; therefore, they were forced to flee their homes for a safe sanctuary. Others, who joined the Maoists once but changed their minds and quit later, were threatened with death. These persons decided to leave their hometown so as not to encounter the Maoists again. Some of the participants expressed that they were tired of giving donations to the Maoists and feeding their cadre, that is why they finally decided to leave their homes. Even others were displaced fearing potential threats or harassment. Even an old single woman in her sixties was compelled to leave her lovely home because her only son was serving in the Royal Nepalese Army. 
There were some common feelings that emerged in each of the FGDs. There was lack of adequate food, clothing and shelter, health and education facilities. They also charged that various government and nongovernment organisations were not serious to deal with the IDPs' problems. Almost all of them have expressed willingness to return to their hometowns if the situation turned out to be normal. One positive development of insurgency that has been found in the discussions was that it had contributed to eliminate caste-based discrimination. Five thematic cases were also collected.

Nepal has ratified and signed more than 17 international human rights treaties and instruments including ICCPR, IESCSR, IECSR, CEDAW, Convention on the Rights of Child and International Convention on Elimination of all Forms of Racial Discrimination. The Nepalese Constitution has the fundamental rights of its citizens enshrined in Articles 11 to 23. The articles are as follows: the right to equality (11), right to freedom (12), press and publication rights (13) rights regarding criminal justice (14), right against preventive detentions (15), right to information (16), right to property (17), cultural and educational rights (18), right to religion (19), rights against exploitation (20), rights against exile (21), right to privacy (22), and right to constitutional remedies. These are the fundamental rights guaranteed to every citizen of the nation without any discrimination on the basis of colour, sex, language, ethnicity, race and religion.

Furthermore, the Constitution adopted in 1990 has directive principles and policies of the state. The article 25 (2) declares that it will be the chief responsibility of the state to maintain conditions suitable for the enjoyment of the fruits of democracy through wider participation of the people in the governance of the country and by way of decentralisation, and to promote general welfare by making provisions for the protection and promotion of human rights by maintaining tranquility and order in the society. The state has taken full responsibility to promote and provide the fruits of development to the entire citizen, and also to promote and respect their rights.

For IDPs all these rights are habitually violated. In 1999 the government had announced the Ganesh Mansingh Peace Campaign that included provisions that the Chief District Officer was responsible for collecting data on IDP families, adequate security arrangements should be made for IDPs, temporary shelter needed to be provided for IDPs, IDPs should be paid Rs 100 daily to travel to their homes, IDPs should be involved in food for work programmes so that their economic status improved, etc. Yet, most of these provisions are ignored by the state and IDPs are left to languish in utter disregard and neglect.

\section{FREQUENCY TABLES}

\subsection{Household Head}

\begin{tabular}{|l|c|c|}
\hline & No. of Respondents & Percentage \\
\hline Yes & 105 & 88.2 \\
\hline No & 14 & 11.8 \\
\hline Total & 119 & 100.0 \\
\hline
\end{tabular}


3.2 Age

\begin{tabular}{|l|c|c|}
\hline & No. of Respondents & Percentage \\
\hline 14-24 Yrs. & 20 & 16.8 \\
\hline 25-39 Yrs. & 41 & 34.5 \\
\hline 40-59 Yrs. & 52 & 43.7 \\
\hline $60 \&$ above & 6 & 5.0 \\
\hline Total & 119 & 100.0 \\
\hline
\end{tabular}

\subsection{Gender Status}

\begin{tabular}{|l|c|c|}
\hline & No. of Respondents & Percentage \\
\hline Female & 45 & 37.8 \\
\hline Male & 74 & 62.2 \\
\hline Others & 0 & 0 \\
\hline Total & 119 & 100.0 \\
\hline
\end{tabular}

\subsection{Literacy Level}

\begin{tabular}{|l|c|c|}
\hline & No. of Respondents & Percentage \\
\hline Illiterate & 38 & 31.9 \\
\hline Can only read & 9 & 7.6 \\
\hline Read and write both & 25 & 21.0 \\
\hline Till primary & 11 & 9.3 \\
\hline Till high school & 30 & 25.2 \\
\hline Above school & 6 & 5.0 \\
\hline No comment & 0 & 0.0 \\
\hline Total & 119 & 100.0 \\
\hline
\end{tabular}




\subsection{Marital Status}

\begin{tabular}{|l|c|c|}
\hline & No. of Respondents & Percentage \\
\hline Married & 112 & 94.1 \\
\hline Unmarried & 4 & 3.4 \\
\hline Divorced / Separated & 0 & 0.0 \\
\hline Widow / Widower & 3 & 2.5 \\
\hline Total & 119 & 100.0 \\
\hline
\end{tabular}

\subsection{Family Members}

\begin{tabular}{|l|c|c|}
\hline & No. of Respondents & Percentage \\
\hline Below 5 & 24 & 20.2 \\
\hline Between 5-8 & 78 & 65.5 \\
\hline Above 8 & 17 & 14.3 \\
\hline Total & 119 & 100.0 \\
\hline
\end{tabular}

\subsection{Adult Members in Family}

\begin{tabular}{|l|c|c|}
\hline & No. of Respondents & Percentage \\
\hline Below 2 & 7 & 5.9 \\
\hline Between 2-5 & 95 & 79.7 \\
\hline Above 5 & 17 & 14.4 \\
\hline Total & 119 & 100.0 \\
\hline
\end{tabular}

\subsection{Children in Family}

\begin{tabular}{|l|c|c|}
\hline & No. of Respondents & Percentage \\
\hline Below 2 & 24 & 20.2 \\
\hline Between 2-5 & 90 & 75.6 \\
\hline Above 5 & 4 & 3.4 \\
\hline
\end{tabular}




\begin{tabular}{|l|c|c|}
\hline No comment & 1 & 0.8 \\
\hline Not applicable & 0 & 0.0 \\
\hline Total & 119 & 100.0 \\
\hline
\end{tabular}

\subsection{Current Occupation}

\begin{tabular}{|l|c|c|}
\hline & No. of Respondents & Percentage \\
\hline Domestic / Agricultural Labour & 44 & 37.0 \\
\hline Industrial Labour & 1 & 0. \\
\hline Self Trade & 23 & 19.3 \\
\hline Others & 51 & 42.9 \\
\hline Multiple answers & 0 & 0.0 \\
\hline Not applicable & 0 & 0.0 \\
\hline Total & 119 & 100.0 \\
\hline
\end{tabular}

\subsection{Current Monthly Income}

\begin{tabular}{|l|c|c|}
\hline & No. of Respondents & Percentage \\
\hline No Income & 0 & 0.0 \\
\hline Below Rs. 1000 & 83 & 69.7 \\
\hline Between Rs. 1000-2000 & 27 & 22.7 \\
\hline Between Rs. 2000-3000 & 4 & 3.4 \\
\hline Above Rs. 3000 & 5 & 4.2 \\
\hline No comment & 0 & 0.0 \\
\hline Total & 119 & 100.0 \\
\hline
\end{tabular}




\subsection{Displacement Reasons}

\begin{tabular}{|l|c|c|}
\hline & No. of Respondents & Percentage \\
\hline Natural Disaster & 6 & 5.0 \\
\hline Development Project & 0 & 0.0 \\
\hline Armed Conflict & 91 & 76.5 \\
\hline Army Occupation & 2 & 1.7 \\
\hline Others & 20 & 16.8 \\
\hline Multiple answers & 0 & 0.0 \\
\hline No comment & 0 & 100.0 \\
\hline Total & 119 & 0.0 \\
\hline
\end{tabular}

\subsection{Years in Displacement Situation}

\begin{tabular}{|l|c|c|}
\hline & No. of Respondents & Percentage \\
\hline One year or less & 33 & 27.7 \\
\hline Between 1-3 Years & 16 & 13.5 \\
\hline Between 3-5 Years & 42 & 35.3 \\
\hline Above 5 Years & 28 & 23.5 \\
\hline No comment & 0 & 0.0 \\
\hline Total & 119 & 100.0 \\
\hline
\end{tabular}

\subsection{Directly journeyed from Original to Current Place}

\begin{tabular}{|l|c|c|}
\hline & No. of respondents & Percentage \\
\hline Yes & 72 & 60.5 \\
\hline No & 46 & 38.7 \\
\hline No comment & 1 & 0.8 \\
\hline Total & 119 & 100.0 \\
\hline
\end{tabular}




\subsection{Single / Multiple Displacement}

\begin{tabular}{|l|c|c|}
\hline & No. of Respondents & Percentage \\
\hline More than once & 37 & 31.1 \\
\hline No & 66 & 55.5 \\
\hline No comment & 16 & 13.4 \\
\hline Total & 119 & 100.0 \\
\hline
\end{tabular}

\subsection{Material Support Available}

\begin{tabular}{|l|c|c|}
\hline & No. of Respondents & Percentage \\
\hline Yes & 41 & 34.5 \\
\hline No & 75 & 63.0 \\
\hline No comment & 3 & 2.5 \\
\hline Total & 119 & 100.0 \\
\hline
\end{tabular}

\subsection{Support Provider}

\begin{tabular}{|l|c|c|}
\hline & No. of Respondents & Percentage \\
\hline Government & 19 & 16.0 \\
\hline NGO/INGO & 24 & 20.2 \\
\hline Others & 0 & 0.0 \\
\hline Multiple answers & 0 & 0.0 \\
\hline No comment & 1 & 0.8 \\
\hline Not applicable & 75 & 63.0 \\
\hline Total & 119 & 100.0 \\
\hline
\end{tabular}




\subsection{Type of Support}

\begin{tabular}{|l|c|c|}
\hline & No. of Respondents & Percentage \\
\hline Economic Support & 1 & 0.8 \\
\hline Shelter & 2 & 1.7 \\
\hline Food & 0 & 0.0 \\
\hline Education & 3 & 2.5 \\
\hline Health & 2 & 1.7 \\
\hline Psychological & 0 & 0.0 \\
\hline Repatriation related & 0 & 0.0 \\
\hline Others & 0 & 0.0 \\
\hline Multiple support & 34 & 28.6 \\
\hline No comment & 3 & 2.5 \\
\hline Not applicable & 74 & 62.2 \\
\hline Total & 119 & 100.0 \\
\hline
\end{tabular}

\subsection{Educational Support for Children}

\begin{tabular}{|l|c|c|}
\hline & No. of Respondents & Percentage \\
\hline Yes & 14 & 11.8 \\
\hline No & 105 & 88.2 \\
\hline Not applicable & 0 & 0.0 \\
\hline Total & 119 & 100.0 \\
\hline
\end{tabular}

\subsection{Do Children Work Anywhere?}

\begin{tabular}{|l|c|c|}
\hline & No. of Respondents & Percentage \\
\hline Yes & 4 & 3.4 \\
\hline No & 115 & 96.6 \\
\hline
\end{tabular}




\begin{tabular}{|l|c|c|}
\hline Not applicable & 0 & 0.0 \\
\hline Total & 119 & 100.0 \\
\hline
\end{tabular}

\subsection{Job Nature of Children}

\begin{tabular}{|l|c|c|}
\hline & No. of Respondents & Percentage \\
\hline Domestic Labour & 0 & 0.0 \\
\hline Industrial Labour & 4 & 3.4 \\
\hline Others & 2 & 1.7 \\
\hline Not applicable & 113 & 94.5 \\
\hline Total & 119 & 100.0 \\
\hline
\end{tabular}

\subsection{Health Condition of Family Members}

\begin{tabular}{|l|c|c|}
\hline & No. of Respondents & Percentage \\
\hline Good & 40 & 33.6 \\
\hline Better & 0 & 0.0 \\
\hline Poor & 79 & 66.4 \\
\hline No comment & 0 & 0.0 \\
\hline Not applicable & 0 & 0.0 \\
\hline Total & 119 & 100.0 \\
\hline
\end{tabular}

\subsection{Medical Assistance in Need}

\begin{tabular}{|l|c|c|}
\hline & No. of Respondents & Percentage \\
\hline Govt. Health Centre & 74 & 62.2 \\
\hline Private Clinic & 24 & 20.1 \\
\hline Ayurvedic Doctor & 0 & 0.0 \\
\hline NGO Supported Clinic & 9 & 7.6 \\
\hline
\end{tabular}




\begin{tabular}{|l|c|c|}
\hline Others & 8 & 6.7 \\
\hline Multiple answers & 2 & 1.7 \\
\hline No comment & 2 & 1.7 \\
\hline Not applicable & 0 & 0.0 \\
\hline Total & 119 & 100.0 \\
\hline
\end{tabular}

\subsection{Recruitment of Children in Armed Forces}

\begin{tabular}{|l|c|c|}
\hline & No. of Respondents & Percentage \\
\hline Yes & 29 & 24.4 \\
\hline No & 89 & 74.8 \\
\hline Not applicable & 1 & 0.8 \\
\hline Total & 119 & 100.0 \\
\hline
\end{tabular}

\subsection{Support to Pregnant / Elderly}

\begin{tabular}{|l|c|c|}
\hline & No. of Respondents & Percentage \\
\hline Yes & 21 & 17.6 \\
\hline No & 94 & 79.0 \\
\hline No comment & 4 & 3.4 \\
\hline Not applicable & 0 & 0.0 \\
\hline Total & 119 & 100.0 \\
\hline
\end{tabular}

\subsection{Major Concern of Pregnant / Elderly}

\begin{tabular}{|l|c|c|}
\hline & No. of Respondents & Percentage \\
\hline No allowance & 1 & 0.8 \\
\hline Lack of security & 3 & 2.5 \\
\hline Lack of basic amenities & 15 & 12.7 \\
\hline Others & 0 & 0.0 \\
\hline
\end{tabular}




\begin{tabular}{|l|c|c|}
\hline Multiple concern & 8 & 6.7 \\
\hline No comment & 0 & 0.0 \\
\hline Not applicable & 92 & 77.3 \\
\hline Total & 119 & 100.0 \\
\hline
\end{tabular}

\subsection{Problems Faces in the Region}

\begin{tabular}{|l|c|c|}
\hline & No. of Respondents & Percentage \\
\hline Social Discrimination & 13 & 10.9 \\
\hline Economic Problems & 42 & 35.3 \\
\hline Lack of Security & 22 & 18.5 \\
\hline Others & 1 & 0.8 \\
\hline Multiple answers & 41 & 34.5 \\
\hline No comment & 0 & 0.0 \\
\hline Total & 119 & 100.0 \\
\hline
\end{tabular}

\subsection{Restriction in Movement}

\begin{tabular}{|l|c|c|}
\hline & No. of Respondents & Percentage \\
\hline Yes & 40 & 33.6 \\
\hline No & 78 & 65.6 \\
\hline No comment & 1 & 0.8 \\
\hline Total & 119 & 100.0 \\
\hline
\end{tabular}

\subsection{Probability of Return}

\begin{tabular}{|l|c|c|}
\hline & No. of Respondents & Percentage \\
\hline Yes & 38 & 32.0 \\
\hline No & 70 & 58.8 \\
\hline No comment & 11 & 9.2 \\
\hline
\end{tabular}




\begin{tabular}{|l|c|c|}
\hline Total & 119 & 100.0 \\
\hline
\end{tabular}

\subsection{Agency Responsible For Return}

\begin{tabular}{|l|c|c|}
\hline & No. of Respondents & Percentage \\
\hline Government & 24 & 20.2 \\
\hline NGO/INGO & 7 & 5.9 \\
\hline Others & 1 & 0.8 \\
\hline Multiple answers & 5 & 4.2 \\
\hline No comment & 3 & 2.5 \\
\hline Not applicable & 79 & 66.4 \\
\hline Total & 119 & 100.0 \\
\hline
\end{tabular}

\subsection{Reasons For No Possibility of Return}

\begin{tabular}{|l|c|c|}
\hline & No. of Respondents & Percentage \\
\hline Socio -Political & 5 & 4.2 \\
\hline Loss of Livelihood & 17 & 14.3 \\
\hline Lack of security & 33 & 27.7 \\
\hline Others & 0 & 0.0 \\
\hline Multiple answers & 27 & 22.7 \\
\hline No comment & 2 & 1.7 \\
\hline Not applicable & 35 & 29.4 \\
\hline Total & 119 & 100.0 \\
\hline
\end{tabular}

\subsection{Knowledge of Policy Mechanisms for IDPs}

\begin{tabular}{|l|c|c|}
\hline & No. of Respondents & Percentage \\
\hline Multiple answer & 118 & 99.2 \\
\hline International (Yes) & 1 & 0.8 \\
\hline
\end{tabular}




\begin{tabular}{|l|c|c|}
\hline Total & 119 & 100.0 \\
\hline
\end{tabular}

\subsection{Nature of Policy Mechanisms}

\begin{tabular}{|l|c|c|}
\hline & No. of Respondents & Percentage \\
\hline Law / Act & 23 & 19.3 \\
\hline Official Documents & 4 & 3.4 \\
\hline Media & 50 & 42.0 \\
\hline Others & 0 & 0.0 \\
\hline Multiple answers & 4 & 3.4 \\
\hline No comment & 1 & 0.8 \\
\hline Not applicable & 37 & 31.1 \\
\hline Total & 119 & 100.0 \\
\hline
\end{tabular}

\subsection{Knowledge of UN Guiding Principles}

\begin{tabular}{|l|c|c|}
\hline & No. of Respondents & Percentage \\
\hline Yes & 30 & 25.2 \\
\hline No & 86 & 72.3 \\
\hline No comment & 3 & 2.5 \\
\hline Not applicable & 0 & 0.0 \\
\hline Total & 119 & 100.0 \\
\hline
\end{tabular}

\subsection{Source of Knowledge About Policy Mechanisms}

\begin{tabular}{|l|c|c|}
\hline & No. of Respondents & Percentage \\
\hline Government representative & 3 & 2.5 \\
\hline NGO worker & 12 & 10.1 \\
\hline Friends & 12 & 10.1 \\
\hline Media & 29 & 24.4 \\
\hline
\end{tabular}




\begin{tabular}{|l|c|c|}
\hline Others & 1 & 0.8 \\
\hline No comment & 1 & 0.8 \\
\hline Not applicable & 61 & 51.3 \\
\hline Total & 119 & 100.0 \\
\hline
\end{tabular}

\subsection{Improvement in Condition Due to Policy Mechanisms}

\begin{tabular}{|l|c|c|}
\hline & No. of Respondents & Percentage \\
\hline Yes & 3 & 2.5 \\
\hline No & 107 & 90.0 \\
\hline No comment & 1 & 0.8 \\
\hline Not applicable & 8 & 6.7 \\
\hline Total & 119 & 100.0 \\
\hline
\end{tabular}

\subsection{Any Suggestions To Agencies For IDPs Rehabilitation}

\begin{tabular}{|l|c|c|}
\hline & No. of Respondents & Percentage \\
\hline Yes & 19 & 16.0 \\
\hline No & 99 & 83.2 \\
\hline No comment & 1 & 0.8 \\
\hline Total & 119 & 100.0 \\
\hline
\end{tabular}

\subsection{Nature of Suggestions to Agencies}

\begin{tabular}{|l|c|c|}
\hline & No. of Respondents & Percentage \\
\hline Stop displacement at source & 0 & 0.0 \\
\hline Contain displacement through policy measures & 1 & 0.8 \\
\hline More social and economic assistance to be provided & 2 & 1.7 \\
\hline More security and care to be provided & 2 & 1.7 \\
\hline Appropriate compensation to be provided & 6 & 5.0 \\
\hline
\end{tabular}




\begin{tabular}{|l|c|c|}
\hline Steps towards early return of the IDPs & 0 & 0.0 \\
\hline Others & 0 & 0.0 \\
\hline Multiple answers & 9 & 7.6 \\
\hline No comment & 0 & 0.0 \\
\hline Not applicable & 99 & 83.2 \\
\hline Total & 119 & 100.0 \\
\hline
\end{tabular}




\section{Sri Lanka}

'Most of the people don't have a birth certificate and identity card. We tried many times but still couldn't obtain these because our registration is still in the north. Most of the people gave up on getting an identity card. So we can't go or travel because we will be arrested. Most people don't know Sinhala. Sinhala is essential in this area." - IDP woman of Sri Lanka

In Sri Lanka displacement is not a recent phenomenon. Sri Lanka witnessed riots against the Tamils since the1950s. The most recent spate of violence started in 1983 when first the Tamils and then the Muslims and Singhalese were displaced as a result of the conflict between the Tamils from northern and eastern Sri Lanka and the state. It followed the butchering of 13 soldiers by the LTTE and the subsequent riots against the Tamil people in Colombo and other cities of the South. All through the 1980s displacement continued. By 1996 the number of IDPs were 800,000 in Sri Lanka. After 2001 ceasefire the number reduced. With the Tsunami on 26 December 2004 the number of IDPs shot up again. Recent violence in Mannar and elsewhere once again increased the number of IDPs.

The Orientation and Training Meeting for the Field Researchers was held on 5 September 2005 at the National Peace Council of Sri Lanka.

\section{Topics discussed during the meeting included:}

○ Purpose of the Research

$\circ$ Introduction on the Donor Organisation and the Implementing Organisation

- Responsibilities of the Field Researchers

- Conducting Interviews

- Conducting Focus Group Discussions

- Conducting Case Studies

- The ethical issues involved

In Sri Lanka researchers completed 100 interviews. The team working on the project conducted interviews in all the Districts where war-affected or Tsunami-affected IDPs resided except in Killinochchi and Mullaituv which are LTTE-controlled areas. They requested permission from the LTTE to conduct interviews in LTTE-controlled areas as well but unfortunately did not succeed. The interviews were conducted in Jaffna, Vavuniya, Anuradhapura, Trincomalee, Batticaloa, Ampara, Hambantota, Matara, Galle, Kalutara, Colombo, Gampha and Puttlam. They conducted three focus group discussions. One of these was in Hambantota with Tsunami-affected IDPs, one in Puttlam with War affected IDPs and another in Ampara with war and Tsunami-affected IDPs. Although 16 was the number expected for the Focus Group Discussions (hereafter FGD), all FGD meetings exceeded 40 IDPs. The researchers received the support of the Grama Niladharis (government-appointed heads of the villages) and Divisional Secretaries (government-appointed agents of the Divison) to organise the meetings. The meetings were very productive and provided a lot of information needed for the project. The researchers also conducted 10 case studies. Approximately about 4 hours were spent with the person who was being interviewed for the Case Study. In some cases two visits were made to gain the relevant information.

Interviews conducted in Colombo, Galle, Hambanthota, Kaluthara and Matara show that natural disaster is the most important cause for displacement. In Anuradhapura, Batticaloa, Jaffna, Puttalam and Trincomalee the major cause for displacement was armed conflict. Only in Anuradhapura one family listed development as a cause for their displacement. In southern Sri Lanka there are blueprints for 
building a dam that might displace over 75000 families. ${ }^{5}$ In this research 48.5 per cent woman IDPs were interviewed. Among the families interviewed there were as many female-headed households as maleheaded households. Most of the heads of households fell in the age bracket of 25-59 years. About 31 per cent of the IDPs interviewed are uneducated. Over 90 per cent of those interviewed are married. Most of those interviewed belonged to nuclear families. They had less than five family members. About onefourth of the families have less than two adult members. Most families (65 per cent) have 2-5 adult members. Most adult IDPs interviewed were either in the domestic or in the agricultural sectors and about 34 per cent of families earned below Rs 1000 a month. Over 25 per cent had a monthly income between Rs 1000 and Rs 2000.

Most war-related IDPs reported that they were displaced multiple times. About 28 per cent reported that they were displaced due to armed conflict. About 35 per cent in all of Sri Lanka had been displaced for more than five years. About 54 per cent are displaced due to natural disaster. About 55 percent reported that they are displaced for one year. In Vavuniya and Anuradhapura only war affected IDPs were interviewed because in these two districts most IDPs are war affected. Tsunami related IDPs in Sri Lanka are recent IDPs and they have been displaced only for one year but war related IDPs are long term IDPs. More than 64 per cent IDPs reported that they have been displaced multiple times. It is interesting to note that in Jaffna, Trincomalee and Vavuniya the respondents reported that they got no support from the government for sending their children to school and in all these places there are greater number of war affected IDPs. This is also of particular importance because sending children to schools is of primary importance to the Tamil IDPs. This is also borne by the fact that most Tamil IDPs in Jaffna, Batticaloa or Trincomalee do not send their children to work.

Most IDPs responded that the major problems they faced were economic. There were a few, largely from Anuradhapura, Ampara, Galle and Jaffna who listed security of their children as their problem. Most IDPs (90.3 per cent) in Sri Lanka got some sort of support. In Anuradhapura, Batticaloa, Colombo, Jaffna and Puttlam some IDPs reported that they did not get any support during their displacement. The government is the largest single support provider. About 7 per cent of the respondents receive support from NGOs. One positive angle for Sri Lankan IDPs is that more than 90 per cent of those interviewed had received some form of support from either the government or from other institutions. The government was the sole support mechanism for 35.9 per cent of the respondents and 49.5 per cent reported that they received support from multiple sources. However, less than 2 per cent of the respondents received any form of economic support. The largest number of IDPs reported that they got support for food.

37.9 per cent of the respondents stated that they were in good health condition and 24.3 per cent also said they had little cause of concern in matters of health. Over 57.3 per cent reported that they got support from government health centres. Only 2.9 per cent respondents received health support from private clinics. NGOs supported healthcare needs for 2.9 per cent of the respondents. 43.7 per cent pregnant women and the elderly reported that they received some support and 41.7 per cent reported that they did not.

But when questioned about the probability of return, 57.3 per cent reported that they saw no chance of return to their original place of residence. In matters of care for IDPs, all replied that they had no knowledge of either local or international mechanisms. In Galle and Colombo a few had replied that they were aware of national mechanisms. This shows that sensitising IDPs on these mechanisms is a primary necessity. When asked whether the IDPs had any recommendation for international agencies 14.6 per cent replied that more care should be taken in providing social and economic assistance, 11.7 per cent said these agencies should take care of their security needs and 41.7 per cent gave multiple replies. The IDPs spoke of social discrimination in their places of rehabilitation because of their status as displaced people.

${ }^{5}$ This number was arrived at during a consultation with IDP activists in Sri Lanka 
On 18 September 2005 at 2 PM in the camp located at Textile Mill, Tangalle in Hambantota district, a discussion was held on the situation of IDPs. Eight women and eight men were supposed to participate, but a group of nearly 40 persons turned up along with the notable Rev. Mirissse Dhammawansa Thero, Chief Incumbent of Vajiragiri Viharaya Tangalle and Y.G.A.Nisantha, Grama Niladhari Indipokunugoda North. This discussion extended well over two hours. There were several families at this discussion, who had lost one of their family members in the disaster. A majority lost their properties. At the Textile Mill camp people live in rooms inside a hall, which are partitioned by planks. For these refugees food, medicines and clothes were provided by various organisations. Ten months have lapsed since the Tsunami, these refugees complained that the assistance was gradually diminishing. Assistance had been received from local and foreign organisations in the beginning. However, many people claim this was not distributed fairly. Fishing boats had been provided to deserving persons with the co-operation of generous persons and foreigners and ownership was assigned to the recipients. During the first few months, the government had provided financial assistance of Rs 5000 per family and a dry ration coupon of Rs 375 had been provided to several refugees. They complain that the grant and the dry ration coupon had been stopped for government employees, but their meager salary is not adequate given their circumstances. However, private sector employees who are in an economically sound position are receiving this assistance. These people feel this is a serious injustice. They further complain that large-scale assistance received from the government is now lying in Divisional Secretariat offices and being misappropriated by certain government employees.

On 10 September 2005 at Pandiruppu, a Tamil dominated coastal village in the Municipal Council area of Kalmunai in the district of Ampara held a discussion on the situation of IDPs. Sixteen persons including men, women, children, household heads, leaders of communities and youths (eight women and eight men) who were affected by war and Tsunami were selected for the focus group discussion. This village was also severely affected by the armed conflict between the Liberation Tigers of Tamil Elam (LTTE) and security forces of the government of Sri Lanka. There were 500 families displaced either by the Tsunami disaster or war. There were no government authorities to extend helping hands for them. Some nongovernmental authorities immediately after the Tsunami visited to arrange some of their basic needs. Many lost family members in the Tsunami, who were the breadwinners. Many women became widows, children were separated from their families. They became unaccompanied and orphans. Many people were made disabled. Many people were psychologically affected. These were outcomes not only of the Tsunami but also the war. The people of this village were continuously suffering from effects of the war. Then once again these people were severely affected by the Tsunami catastrophe. These families are still living in the temporary shelters provided by some NGOs.

During the war there was no security. The government forces without reason arrested people when Emergency regulations were in force. The security forces arrested women and elders. They were taken and kept in detention camps for long periods of time without legal process. Those suspected of being the members of LTTE were tortured. Sometimes they were asked to identify members of LTTE or any other armed groups. They were not produced before the courts of law. They had to face a daily round up for security checking. They could not save the children who were also were arrested and tortured. Many people disappeared. They could not send their children to the school. Most people lost family members who were mostly shot dead by the security forces or sometimes by unknown armed groups. Armed groups forcefully recruited children as soldiers. Many children who were in the war zones gradually became mentally disabled. There was no proper mechanism to look after the psychosocial well being of the children of the war zones. Many children dropped out of school due to poverty.

Many families lost their family members including women and children in the Tsunami. On the day of the Tsunami women and children were doing their morning duties at home when the adult males had gone out to work. Therefore more women and children lost their lives compared to men. Many women also lost their husbands and became widows. Many children lost their parents and family members and became 
orphans. Many people became disabled. The two temples, which were situated close to the beach, were completely destroyed by the Tsunami. The debris of the damaged buildings covered the roads. The people could not get safe drinking water. The power supply was totally disconnected because most of the electrical posts were completely damaged by the tidal waves. The communication system was totally out of order. The hospital was inadequately equipped to deal with the crisis.

The people whose houses were fully damaged were assessed at Rs 2,50,000 and partly damaged at Rs 100.000. The first installment of the compensation was given to the tsunami affected peoples. The main income sources of the people of this village are fishing and farming. The household heads of the families do not currently have employment. They lost their equipment used for their work. All the fishing boats and nets used for fishing by the people of this village damaged by the Tsunami waves. The sea took their cattle away. They do not have means to run their lives. They do not have enough food. Children, pregnant women and lactating mothers are unable to get adequate nutrition.

The human rights of the children and women are at risk. Many children were separated from their family members and became unaccompanied. Many people became disabled. In the IDP camps women and children had to face many problems because they are vulnerable. They could not get enough food and medical facilities. There was no one to look after them. There was no one to look after their water and sanitation needs. Women and children were subjected to sexual abuse. There was no access to counselling.

They lost all of their property in the Tsunami, including household items and money, as well as important legal documents such as passports, identity cards, copies of deeds, school certificates, etc. Their children were psychologically affected and need treatment. The schools which they were attending were severely damaged. Their education was disrupted. They need to continue their education as a way of returning to normal life. The displaced people do not want to return to their habitual place of residence as they fear another Tsunami.

In Puttlam 16 persons attended a discussion in the same month who all belonged to a camp of war affected people. The relief work and support by the government does not reach the vulnerable people properly. Even after 15 years they are struggling to have their essential needs. They do not have proper housing facilities, food and clothes. In the words of one man, 'Most of the people came with only the clothes they were wearing. We came a long distance on foot. Elders, youngsters and small children also came on foot. We didn't have any help. We lost everythi ng. LTTE people didn't care. Most of the Muslim leaders went and asked to stop the displacement. But they didn't change their decision."

In this camp children stated that they could not go to school because of lack of income of their families. Also without a school uniform and the money to buy books and stationary the children could not go to school. The Sahira School principal didn't give permission to children to continue education without wearing a white uniform. One mother said, "We would like to give education to our children but we have some obstacles. We don't have a school nearby. Our children have to walk more than $6 \mathrm{~km}$ or have to hire an auto. We don't have enough bus services. Because of that reason our girls can't continue their education." Another mother stated, "Every day we have to spend a lot of money for our children to go school. Every day school teachers are asking for money. That is also the main barrier to continue children's education. Most of the students stop their education at primar y level. Very few in our camp go up to Ordinary Level."

When asked about the problems that they faced one IDP woman answered, 'Most of the people don't have a birth certificate and identity card. We tried many times but still couldn't obtain these because our registration is still in the north. Most of the people gave up on getting an identity card. So we can't go or travel because we will be arrested. Most of the people don't know Sinhala. Sinhala is essential in this 
area." Another respondent replied, 'W e don't have a clinic. We appealed to the authorities, but still no answer. We have been given a very small area to build cottages. So we don't have enough sanitation. We don't have enough toilets. So health is the major problem to us."

When questioned about discriminations faced one respondent replied, 'Some people look at us and call us refugees. We have to face this type of experience in public places such as in the market, the lake and also in the public sector some officers function in a discriminatory manner. They don't take care of our problems and don't listen to our cries. But I have to mention that our Grama Niladari is a good person. He serves us irrespective of race, religion and other differences. We always appreciate him. He carries out his duty to us without any discrimination."

Most of the IDPs in Sri Lanka spoke about the quality of their lives. They wanted a life without persecution or discrimination. Also the conflict-related IDPs were disturbed by all the attention going to the Tsunami-affected IDPs. They wanted both groups to be treated equally. In many cases Tsunamiaffected IDPs got rehabilitation even when war-affected IDPs were awaiting it for years. Their monthly rations were also substantially lower than those affected by the Tsunami. The war-affected IDPs were baffled by this partiality shown by the state. They have raised a demand that rehabilitation should come to people on the basis of how long they have been displaced. Some Tsunami-affected IDPs have got new houses but war-affected IDPs are often languishing in camps. Even UNHCR officials are aware of this discrepancy but there is little that they can do. With escalating violence in Sri Lanka today everyone associated with the IDPs know that tougher times are ahead of them and they can do little to change them.

\section{FREQUENCY TABLES}

\subsection{Household Head}

\begin{tabular}{|l|c|c|}
\hline & No. of Respondents & Percentage \\
\hline Yes & 69 & 67.0 \\
\hline No & 34 & 33.0 \\
\hline Total & 103 & 100.0 \\
\hline
\end{tabular}

4.2 Age

\begin{tabular}{|l|c|c|}
\hline & No. of Respondents & Percentage \\
\hline 14-24 Yrs. & 7 & 6.8 \\
\hline 25-39 Yrs. & 36 & 35.0 \\
\hline $40-59$ Yrs. & 52 & 50.5 \\
\hline $60 \&$ above & 8 & 7.8 \\
\hline Total & 103 & 100.0 \\
\hline
\end{tabular}




\subsection{Gender Status}

\begin{tabular}{|l|c|c|}
\hline & No. of Respondents & Percentage \\
\hline Female & 50 & 48.5 \\
\hline Male & 53 & 51.5 \\
\hline Others & 0 & 0.0 \\
\hline Total & 103 & 100.0 \\
\hline
\end{tabular}

\subsection{Literacy Level}

\begin{tabular}{|l|c|c|}
\hline & No. of Respondents & Percentage \\
\hline Illiterate & 20 & 19.4 \\
\hline Can only read & 12 & 11.7 \\
\hline Read and write both & 16 & 15.5 \\
\hline Till primary & 32 & 31.1 \\
\hline Till high school & 22 & 21.4 \\
\hline Above school & 1 & 1.0 \\
\hline No comment & 0 & 0.0 \\
\hline Total & 103 & 100.0 \\
\hline
\end{tabular}

\subsection{Marital Status}

\begin{tabular}{|l|c|c|}
\hline & No. of Respondents & Percentage \\
\hline Married & 96 & 93.2 \\
\hline Unmarried & 6 & 5.8 \\
\hline Divorced / Separated & 0 & 0.0 \\
\hline Widow / Widower & 0 & 0.0 \\
\hline Not applicable & 1 & 1.0 \\
\hline Total & 103 & 100.0 \\
\hline
\end{tabular}




\subsection{Family Members}

\begin{tabular}{|l|c|c|}
\hline & No. of Respondents & Percentage \\
\hline Below 5 & 58 & 56.3 \\
\hline Between 5-8 & 41 & 39.8 \\
\hline Above 8 & 4 & 3.9 \\
\hline Total & 103 & 100.0 \\
\hline
\end{tabular}

\subsection{Adult Members in Family}

\begin{tabular}{|l|c|c|}
\hline & No. of Respondents & Percentage \\
\hline Below 2 & 26 & 25.2 \\
\hline Between 2-5 & 65 & 63.1 \\
\hline Above 5 & 10 & 9.7 \\
\hline Not applicable & 2 & 1.9 \\
\hline Total & 103 & 100.0 \\
\hline
\end{tabular}

\subsection{No. of Children in Family}

\begin{tabular}{|l|c|c|}
\hline & No. of Respondents & Percentage \\
\hline Below 2 & 38 & 36.9 \\
\hline Between 2-5 & 48 & 46.6 \\
\hline Above 5 & 8 & 7.8 \\
\hline Not applicable & 9 & 8.8 \\
\hline Total & 103 & 100.0 \\
\hline
\end{tabular}

\subsection{Current Occupation}

\begin{tabular}{|l|l|l|}
\hline & No. of Respondents & Percentage \\
\hline Domestic / Agricultural Labour & 64 & 62.1 \\
\hline Industrial Labour & 2 & 1.9 \\
\hline
\end{tabular}




\begin{tabular}{|l|l|l|}
\hline Self Trade & 2 & 1.9 \\
\hline Others & 14 & 13.6 \\
\hline Multiple answers & 0 & 0.0 \\
\hline Not applicable & 21 & 20.4 \\
\hline Total & 103 & 100.0 \\
\hline
\end{tabular}

\subsection{Current Monthly Income}

\begin{tabular}{|l|c|c|}
\hline & No. of Respondents & Percentage \\
\hline No Income & 4 & 3.9 \\
\hline Below Rs. 1000 & 35 & 34.0 \\
\hline Between Rs. 1000-2000 & 26 & 25.2 \\
\hline Between Rs. 2000-3000 & 13 & 12.6 \\
\hline Above Rs. 3000 & 12 & 11.7 \\
\hline No comment & 13 & 12.6 \\
\hline Total & 103 & 100.0 \\
\hline
\end{tabular}

\subsection{Displacement Reasons}

\begin{tabular}{|l|c|c|}
\hline & No. of Respondents & Percentage \\
\hline Natural Disaster & 56 & 54.4 \\
\hline Development Project & 1 & 1.0 \\
\hline Armed Conflict & 29 & 28.2 \\
\hline Army Occupation & 0 & 0.0 \\
\hline Others & 0 & 0.0 \\
\hline Multiple answers & 17 & 16.5 \\
\hline No comment & 0 & 0.0 \\
\hline Total & 103 & 100.0 \\
\hline
\end{tabular}


4.12 Years in Displacement Situation

\begin{tabular}{|l|c|c|}
\hline & No. of Respondents & Percentage \\
\hline One year or less & 57 & 55.3 \\
\hline Between 1-3 Years & 3 & 2.9 \\
\hline Between 3-5 Years & 6 & 5.8 \\
\hline Above 5 Years & 37 & 35.9 \\
\hline No comment & 0 & 0.0 \\
\hline Total & 103 & 100.0 \\
\hline
\end{tabular}

\subsection{Directly journeyed from Original to Current Place}

\begin{tabular}{|l|c|c|}
\hline & No. of respondents & Percentage \\
\hline Yes & 35 & 34.0 \\
\hline No & 66 & 64.1 \\
\hline No comment & 2 & 1.9 \\
\hline Total & 103 & 100.0 \\
\hline
\end{tabular}

\subsection{Single / Multiple Displacement}

\begin{tabular}{|l|c|c|}
\hline & No. of Respondents & Percentage \\
\hline More than once & 88 & 85.4 \\
\hline No & 14 & 13.6 \\
\hline No comment & 1 & 1.0 \\
\hline Total & 103 & 100.0 \\
\hline
\end{tabular}

\subsection{Material Support Available}

\begin{tabular}{|l|c|c|}
\hline & No. of Respondents & Percentage \\
\hline Yes & 93 & 90.3 \\
\hline
\end{tabular}




\begin{tabular}{|l|c|c|}
\hline No & 10 & 9.7 \\
\hline No comment & 0 & 0.0 \\
\hline Total & 103 & 100.0 \\
\hline
\end{tabular}

\subsection{Support Provider}

\begin{tabular}{|l|c|c|}
\hline & No. of Respondents & Percentage \\
\hline Government & 37 & 35.9 \\
\hline NGO/INGO & 7 & 6.8 \\
\hline Others & 1 & 1.0 \\
\hline Multiple answers & 51 & 49.5 \\
\hline No comment & 0 & 0.0 \\
\hline Not applicable & 7 & 6.8 \\
\hline Total & 103 & 100.0 \\
\hline
\end{tabular}

\subsection{Type of Support}

\begin{tabular}{|l|c|c|}
\hline & No. of Respondents & Percentage \\
\hline Economic Support & 2 & 1.9 \\
\hline Shelter & 2 & 1.9 \\
\hline Food & 24 & 23.3 \\
\hline Education & 0 & 0.0 \\
\hline Health & 0 & 0.0 \\
\hline Psychological & 0 & 0.0 \\
\hline Repatriation related & 0 & 0.0 \\
\hline Others & 0 & 0.0 \\
\hline Multiple support & 69 & 5.8 \\
\hline Not applicable & 6 & \\
\hline
\end{tabular}




\begin{tabular}{|l|c|c|}
\hline Total & 103 & 100.0 \\
\hline
\end{tabular}

\subsection{Educational Support for Children}

\begin{tabular}{|l|c|c|}
\hline & No. of Respondents & Percentage \\
\hline Yes & 36 & 35.0 \\
\hline No & 40 & 38.8 \\
\hline Not applicable & 27 & 26.2 \\
\hline Total & 103 & 100.0 \\
\hline
\end{tabular}

\subsection{Do Children Work Anywhere?}

\begin{tabular}{|l|c|c|}
\hline & No. of Respondents & Percentage \\
\hline Yes & 20 & 19.4 \\
\hline No & 51 & 49.5 \\
\hline Not applicable & 32 & 31.1 \\
\hline Total & 103 & 100.0 \\
\hline
\end{tabular}

\subsection{Job Nature of Children}

\begin{tabular}{|l|c|c|}
\hline & No. of Respondents & Percentage \\
\hline Domestic Labour & 9 & 8.7 \\
\hline Industrial Labour & 3 & 2.9 \\
\hline Others & 9 & 8.7 \\
\hline Multiple answers & 1 & 1.0 \\
\hline Not applicable & 81 & 78.7 \\
\hline Total & 103 & 100.0 \\
\hline
\end{tabular}

\subsection{Health Condition of Family Members}

\begin{tabular}{|l|l|l|}
\hline & No. of Respondents & Percentage \\
\hline
\end{tabular}




\begin{tabular}{|l|c|c|}
\hline Good & 38 & 36.9 \\
\hline Better & 25 & 24.3 \\
\hline Poor & 39 & 37.9 \\
\hline No comment & 1 & 1.0 \\
\hline Not applicable & 0 & 0.0 \\
\hline Total & 103 & 100.0 \\
\hline
\end{tabular}

\subsection{Medical Assistance in Need}

\begin{tabular}{|l|c|c|}
\hline & No. of Respondents & Percentage \\
\hline Govt. Health Centre & 59 & 57.3 \\
\hline Private Clinic & 3 & 2.9 \\
\hline Ayurvedic Doctor & 0 & 0.0 \\
\hline NGO Supported Clinic & 3 & 2.9 \\
\hline Others & 4 & 3.9 \\
\hline Multiple answers & 31 & 30.1 \\
\hline No comment & 3 & 2.9 \\
\hline Not applicable & 0 & 0.0 \\
\hline Total & 103 & 100.0 \\
\hline
\end{tabular}

\subsection{Recruitment of Children in Armed Forces}

\begin{tabular}{|l|c|c|}
\hline & No. of Respondents & Percentage \\
\hline Yes & 5 & 4.9 \\
\hline No & 57 & 55.3 \\
\hline Not applicable & 41 & 39.8 \\
\hline Total & 103 & 100.0 \\
\hline
\end{tabular}




\subsection{Support to Pregnant / Elderly}

\begin{tabular}{|l|c|c|}
\hline & No. of Respondents & Percentage \\
\hline Yes & 45 & 43.7 \\
\hline No & 43 & 41.7 \\
\hline No comment & 15 & 14.6 \\
\hline Total & 103 & 100.0 \\
\hline
\end{tabular}

\subsection{Major Concern of Pregnant / Elderly}

\begin{tabular}{|l|c|c|}
\hline & No. of Respondents & Percentage \\
\hline No allowance & 3 & 2.9 \\
\hline Lack of security & 1 & 1.0 \\
\hline Lack of basic amenities & 22 & 21.4 \\
\hline Others & 12 & 11.7 \\
\hline Multiple concern & 9 & 8.7 \\
\hline No comment & 4 & 3.9 \\
\hline Not applicable & 52 & 50.5 \\
\hline Total & 103 & 100.0 \\
\hline
\end{tabular}

\subsection{Problems Faces in the Region}

\begin{tabular}{|l|c|c|}
\hline & No. of Respondents & Percentage \\
\hline Social Discrimination & 10 & 9.7 \\
\hline Economic Problems & 46 & 44.7 \\
\hline Lack of Security & 9 & 8.7 \\
\hline Others & 3 & 2.9 \\
\hline Multiple answers & 27 & 26.2 \\
\hline No comment & 8 & 7.8 \\
\hline
\end{tabular}




\begin{tabular}{|l|c|c|}
\hline Total & 103 & 100.0 \\
\hline
\end{tabular}

\subsection{Restriction in Movement}

\begin{tabular}{|l|c|c|}
\hline & No. of Respondents & Percentage \\
\hline Yes & 27 & 26.2 \\
\hline No & 74 & 71.8 \\
\hline No comment & 2 & 2.0 \\
\hline Total & 103 & 100.0 \\
\hline
\end{tabular}

\subsection{Probability of Return}

\begin{tabular}{|l|c|c|}
\hline & No. of Respondents & Percentage \\
\hline Yes & 39 & 37.9 \\
\hline No & 59 & 57.3 \\
\hline No comment & 5 & 4.9 \\
\hline Total & 103 & 100.0 \\
\hline
\end{tabular}

\subsection{Agency Responsible For Return}

\begin{tabular}{|l|c|c|}
\hline & No. of Respondents & Percentage \\
\hline Government & 19 & 18.4 \\
\hline NGO/INGO & 5 & 4.9 \\
\hline Others & 8 & 7.8 \\
\hline Multiple answers & 16 & 15.5 \\
\hline No comment & 15 & 14.6 \\
\hline Not applicable & 40 & 38.8 \\
\hline Total & 103 & 100.0 \\
\hline
\end{tabular}

\subsection{Reasons For No Possibility of Return}




\begin{tabular}{|l|c|c|}
\hline & No. of Respondents & Percentage \\
\hline Socio -Political & 0 & 0.0 \\
\hline Loss of Livelihood & 5 & 4.9 \\
\hline Lack of security & 15 & 14.6 \\
\hline Others & 19 & 18.4 \\
\hline Multiple answers & 21 & 20.4 \\
\hline No comment & 2 & 1.9 \\
\hline Not applicable & 41 & 39.8 \\
\hline Total & 103 & 100.0 \\
\hline
\end{tabular}

\subsection{Knowledge of Policy Mechanisms for IDPs}

\begin{tabular}{|l|c|c|}
\hline & No. of Respondents & Percentage \\
\hline Multiple answer & 68 & 66.0 \\
\hline No comment & 35 & 34.0 \\
\hline Total & 103 & 100.0 \\
\hline
\end{tabular}

\subsection{Nature of Policy Mechanisms}

\begin{tabular}{|l|c|c|}
\hline & No. of Respondents & Percentage \\
\hline Law / Act & 2 & 1.9 \\
\hline Official Documents & 4 & 3.9 \\
\hline Media & 26 & 25.2 \\
\hline Others & 2 & 1.9 \\
\hline Multiple answers & 11 & 10.7 \\
\hline No comment & 36 & 35.0 \\
\hline Not applicable & 22 & 21.4 \\
\hline Total & 103 & 100.0 \\
\hline
\end{tabular}




\subsection{Knowledge of UN Guiding Principles}

\begin{tabular}{|l|c|c|}
\hline & No. of Respondents & Percentage \\
\hline Yes & 41 & 39.8 \\
\hline No & 28 & 27.2 \\
\hline No comment & 33 & 32.0 \\
\hline Not applicable & 1 & 1.0 \\
\hline Total & 103 & 100.0 \\
\hline
\end{tabular}

\subsection{Source of Knowledge About Policy Mechanisms}

\begin{tabular}{|l|c|c|}
\hline & No. of Respondents & Percentage \\
\hline Government representative & 1 & 1.0 \\
\hline NGO worker & 2 & 1.9 \\
\hline Friends & 0 & 0.0 \\
\hline Media & 32 & 31.1 \\
\hline Others & 4 & 3.9 \\
\hline Multiple answers & 19 & 18.4 \\
\hline No comment & 30 & 29.1 \\
\hline Not applicable & 15 & 14.6 \\
\hline Total & 103 & 100.0 \\
\hline
\end{tabular}

\subsection{Improvement in Condition Due to Policy Mechanisms}

\begin{tabular}{|l|c|c|}
\hline & No. of Respondents & Percentage \\
\hline Yes & 36 & 35.0 \\
\hline No & 21 & 20.4 \\
\hline No comment & 35 & 34.0 \\
\hline Not applicable & 11 & 10.7 \\
\hline
\end{tabular}




\begin{tabular}{|l|c|c|}
\hline Total & 103 & 100.0 \\
\hline
\end{tabular}

\subsection{Any Suggestions To Agencies For IDPs Rehabilitation}

\begin{tabular}{|l|c|c|}
\hline & No. of Respondents & Percentage \\
\hline Yes & 83 & 80.6 \\
\hline No & 8 & 7.8 \\
\hline No comment & 12 & 11.6 \\
\hline Total & 103 & 100.0 \\
\hline
\end{tabular}

\subsection{Nature of Suggestions to Agencies}

\begin{tabular}{|l|c|c|}
\hline & No. of Respondents & Percentage \\
\hline Stop displacement at source & 3 & 2.9 \\
\hline Contain displacement through policy measures & 2 & 1.9 \\
\hline More social and economic assistance to be provided & 12 & 14.6 \\
\hline More security and care to be provided & 4 & 3.9 \\
\hline Appropriate compensation to be provided & 5 & 4.9 \\
\hline Steps towards early return of the IDPs & 4 & 3.9 \\
\hline Others & 43 & 41.7 \\
\hline Multiple answers & 11 & 10.7 \\
\hline No comment & 4 & 3.9 \\
\hline Not applicable & 103 & $100.0 \mathrm{~S}$ \\
\hline Total & & \\
\hline
\end{tabular}




\section{India}

'I stood on the hill across and located my home on this side, saw my own people but this short distance cannot be spanned in a short time. It takes hours to travel and before that days and months to complete official papers ....We [Hussain and his son] could have easily shouted at each other but we cannot meet." - Md Hussain of Poonch

Within India research was undertaken in North-east India, Orissa, Gujarat and Jammu and Kashmir.

\section{Assam}

Research was undertaken in North-east India mainly in the state of Assam particularly in the districts of Kokrajhar, Bongaigaon, and Dhubri. The survey covered the IDPs due to ethnic violence during the Bodoland agitation between Bodos, Adivasis and Muslims. The researchers conducted focus group discussions in these areas with the IDPs and interviewed both men and women. North-east India has witnessed protracted conflicts and displacements of thousands of people in the last few decades. In Assam in the last count (August 2004) a total of 37,677 families (2,37,768 people) were staying in makeshift camps in three districts of western Assam - Kokrajhar, Bongaigaon and Dhubri. These IDPs are all but forgotten. The displacement in these areas has happened due to an ethnic community claiming exclusive rights over a space that it defines as its "homeland" on the ground that it is the "original inhabitant" of the land. By the same token, they have held that outsiders have no right to settle there.

Kokrajhar is one of the 23 districts of Assam and can be described as the gateway to the northeastern region of India. Both road and rail touch this district at Srirampur before they go on to other districts in Assam and the other northeastern states. The district has a total area of 3,169.22 sq. $\mathrm{km}$. and a total population of 9,30,404 according to the Census 2001. The Bodo community comprises the majority in Kokrajhar district. It also has a sizeable Rajbongshi and Santhal population in addition to Muslims, whose fast increasing population is generally attributed to the infiltration from Bangladesh. Kokrajhar is now the headquarters of the Bodoland Autonomous Council created in 1993. The demand for regional autonomy by the plains tribes of Assam had its impact on the Bodo people living in this district as well. The Plains Tribe Council of Assam (PTCA) was the organisation that first spearheaded the movement for a separate state of ' Udayachal' for the plains tribes of Assam living in the northern bank of the Brahmaputra Valley. Later on, the All Bodo Students' Union (ABSU) came to the fore and started a movement for a separate state of Bodoland. The agitation was vigorous and also violent from 1985 to 1992 till the State Government worked out an accord with the ABSU. The Bodoland Accord was signed on 20 February 1993, by which the Bodoland Autonomous Council (BAC) came into being. The present BAC area is spread across seven districts of the state. In some areas under the BAC there were more than 50 per cent non-Bodo population composed of Asamiya Hindus, Asamiya Muslims, Rabhas, Na-Asamiyas Muslims, Bengali Hindus, Santahlis and Nepalis. In fact in large part of BAC Bodos didn't constitute a simple majority. This dissimilarity stalled the process of clear demarcation of the boundaries of BAC and Assam state's refusal to hand over the non-Bodo majority areas further complicated the matters. This vindicated the stance of separatists National Democratic Front of Bodoland (NDFB), who had opposed the accord. And, therefore as argued by many in order to establish their majority and gain complete hold over the territory ethnic cleansing process started. The ethnic cleansing started with large-scale attack on Muslims of Bengali descent in October 1993. These migrants, mostly peasants, had taken over land throughout Assam, initially causing displacement of ethnic Assamese and the tribal peasantry. In the 1980s the Assamese agitators targeted them and a decade later they became the targets of the Bodo militants. This continued in 1994 and resulted in massacre of around 100 Muslims, mostly women and children, and 
some 20,000 were displaced in Kokrajhar and Bongaigaon districts. In 1995-96 Bodo militants started attacking the Bengali Hindus and finally in May-June 1996 launched massive attacks on the Adivasis throughout western Assam. However, unlike Muslims, the Adivasis and Bengali Hindus formed their own militant groups and started attacking Bodo villages. The Adivasi Cobra Militants of Assam (ACMA) and Bengali Liberation Tigers, a group formed by Bengali Hindus, teamed up and attacked several Bodo villages after the massive Bodo- sponsored violence of May-June 1996. After this initial outbreak, conflict between the two ethnic groups became a regular feature in western Assam. In 1998, the violence intensified just when some of the displaced people were returning home. Thousands fled their villages again, exacerbating the displacement. After 1993, the Bodos have systematically targeted the non-Bodo communities in the four districts they see as forming the core of their separate homeland.

In 1997, the majority of the refugees returned to their original villages and homesteads, with government provided rehabilitation grants. However, 23,000 families, designated "encroachers" (illegally occupying homestead lands), were unable to return. In addition, there were about 3,000 families who - despite having received rehabilitation grants - were unable to return to their original homes, living in small huts made of bamboo and plastic sheets, close their to their original villages or on relief camp sites. However, violence erupted in 1998 on two occasions, causing people to once again flee to the safety of the camps. More than 110,000 people from the Santhal-Bodo conflict still remain in relief camps. Assam officials say only about half of the quarter million displaced people were still left in relief camps. Assam government records, as of December 2005, indicates that only 33,362 displaced people were left in the camps in Kokrajhar district and 74,123 were left in the camps in Gosaigaon district. According to official reports, in January 2004, 19 camps housed Santhals, three housed Bodos and one the Rabha ethnic group.

\section{Assam:Iinternally Displaced in the Bodo-Santhal Conflict (December 2005)}

- In May 1996, more than 250,000 persons were displaced as a result of Bodo large-scale attacks on ethnic Santhals.

- In 1997, the majority returned home, but were forced to flee after renewed fighting during 1998.

- While thousands having returned to their homes, retaliation from Santhals and other non-Bodo communities has, in turn, resulted in significant displacement of the Bodo population from areas where they are a minority.

- The situation in the district has improved considerably in the past couple of years and many Adivasis have begun returning home.

- More than 100,000 Santhals remain displaced in 32 camps.

- An unknown number of Bodos are also living in three relief camps.

- Approximately 25,000 Muslims are yet to be rehabilitated who don't think their return is possible and are completely neglected due to the volatile political situation and their minority situation.

The field research and interaction with the IDPs completely refuted the claim of the state government that they had been rehabilitated. It was observed that in some cases the second generation of IDPs were in camps, who had no access to basic amenities. They had no access to education and health facilities. If the ground realities are improving with peace prevailing after the accord, the fear is still there in the minds of Santhals who are yet to take charge of their lands. Many of them are still staying away from their villages and visit there only during the day and return to safer Adivasis villages. In fact the violence has made all the parties involved more conscious and aware of their ethnic identities and caused further polarisation. If on the one hand Santhals are preparing for their return, Muslims are not at all confident of returning to their land. They have lost all hope and perched themselves on the side of National Highway in Goriamari. Their lot is worse because of their minority status and growth of communal forces in the region. Since infiltration from the Bangladesh border has always been an important issue in the politics of the region no political party has ever been able to help them out. So, they have to fend for themselves. 
During the focus group discussion largely men responded to our queries. Actually, given the nature of the society whenever somebody comes to talk men always tend to speak and women stand and listen. Even though women did not speak in public but they were interviewed in private. Their responses show that their concerns were different. For women living in camp was a different experience because they ran their house in difficult circumstances and arranged for necessities such as drinking water, fuel, ration, etc., while men sat and gossiped whole day because they were unemployed and had time in their hands.

As is well known, living in camps as IDPs or refugees is never easy, but for these IDPs in Assam the problem gets further compounded as they are virtually disowned by the state due to their minority status. They face multiple problems in the region.

- Residence: They have no proper shelter and are living in completely unhygienic situations. Their shelter is not meant to withstand the heat, cold or rain. It is barely able to give them some protection but is not of much use.

- Employment: Actually the whole community is unemployed and nobody has a respectable employment. They have not been able to get employment because their presence in the neighbourhood is seen with suspicion. It has been reported that many of them have migrated to cities elsewhere in India and the women are engaged in prostitution on the highway. The unemployment has affected their family structure and every aspect of life in a negative way.

- Education: Except for a madarsa in nearby locality there is no facility for education of their children. This madarsa was started a year or two ago, before which nothing existed there.

- Food: They barely manage to have three meals a day. They are dependent on casual work and on foraging in the nearby forests and fishing in the river.

- Security: Even though there is no direct threat for them from Bodos, they are insecure because of their location next to the highway. We were told that many of their children had died since they came here. Since the highway is extremely busy their movement is very much restricted and it is very difficult for children to feel free.

- Psychological stress: Because of unemployment, insecurity, hunger, frustration and alienation they are constantly under psychological stress. This has led to an increase in the incidence of domestic violence and fights amongst the IDPs.

Major problems faced by these groups are related to food, work and security. As mentioned before there is a substantial lack of work opportunities, which has led to major instances of malnutrition and poor health conditions. Over the years many of them have died prematurely in the absence of credible health facilities. Lack of sanitation and water facilities has resulted in waterborne diseases. The situation has further compounded because of their camp's location on the banks of a river, which makes them vulnerable to waterborne diseases such as diarrhoea and malaria.

Discriminations prevail even during their life in displacement. These discriminations are on the basis of gender, caste, religion, ethnicity, or political ideology. The displacement situation does break some boundaries, as any adversity does, but the older practices of discrimination continues once life starts beginning to settle down in camps. As mentioned above women continue to bear the load of household work and family and also suffer at the hands of male members. In fact, government also discriminates on the basis of religion and ethnicity as is evident in the treatment and attention given to Adivasis and Muslims, both internally displaced communities. As a result of this discrimination today Adivasis have started returning to their homes, but Muslims are still languishing in camps and don't see any possibility of being able to return to their land.

\section{Orissa}

In Orissa the fieldwork was undertaken in the areas where the people were displaced due to the construction of the Hirakud Dam on the river Mahanadi in Sambalpur district. Also those who were 
displaced because of the coal mining by Mahanadi Coalfields Limited (MCL) in Jharsuguda district and the Ib Thermal Power Station (ITPS) of the Orissa Power Generation Corporation (OPGC) in Jharsuguda district, were interviewed. The respondents of the last case are located in the various villages, camps, and resettlement colonies of Lakhanpur block of Jharsuguda district of Orissa. While the displacement due to the dam happened way back in 1950s, the other two cases of MCL and ITPS are recent, i.e. of the 1990s. Some of the women displaced due to Hirakud Dam have also been affected (not displaced) due to ITPS. This study captures the voices of the women displaced due to all the above three instances and doubly affected due to ITPS.

Orissa has a high poverty ratio (about 50 per cent). The New Economic Policy along with liberalisation, privatisation and globalisation has created a situation in the state where industrialisation and large projects have become the thrust of the government. Mining, dams and industry are causing displacement in thousands without creating necessary social nets which will safe guard the interests of the people. The state has no R\&R policy, though recently (2005) it is being drafted along with some civil society agencies and UNDP. It is hoped that the voices of the people will find a place in the new policy. The different projects have followed different norms. The water resources department of the government of Orissa however has had a rehabilitation policy since the first instances of displacement in the state has been due to the mega dams and the irrigation and hydel power projects.

Statistical figures indicate that till 2000 in Orissa, about 20 lakh people have been directly affected by development projects in varying degrees out of which about 5 lakh have been physically displaced losing their home and hearth from their original habitat. Figures further indicate that while dam/irrigation projects alone have displaced nearly 3.5 lakh people out of the 5 lakh, which is roughly 70 per cent of the total displaced population, industrial projects have displaced about 60,000 people, which is 12 per cent of the total displaced, mining projects -3.37 per cent, urban development projects -12.86 per cent, thermal projects - the 2.60 per cent and wildlife sanctuaries -0.5 per cent. Although the above figures account for the already completed projects, there are a host of other projects which are either ongoing or are in the pipeline in which about 2 lakh more people are expected to be displaced.

The Hirakud Dam project in Orissa was the first major multipurpose project that was executed in postIndependence India as a part of the planned development process. It displaced 22,144 families from 249 villages in Orissa (108 fully and 141 partially) and 36 villages (three fully and 33 partially) in Madhya Pradesh (total 285 villages), comprising a population of 1,10,000. The vast artificial reservoir submerged 74,300 ha of land including 23,988 ha of forest cover and 49,888 ha of agricultural land. While researchers have put the number of persons displaced by the dam at close to 1.6 lakh, the official figure is only 1.1 lakh. As the displacement in case of Hirakud happened as early as 1956, a sum of only Rs 340 lakh has been paid to the oustees out of the Rs 960 lakh allotted. Out of the total displaced families only 4744 families ( 21.42 per cent) were rehabilitated which included the tribals and scheduled castes. Out of the families rehabilitated, 3098 (65.3 per cent) had not got full compensation during as late as 1990s. The Mahanadi Coalfields Limited (a subsidiary of Coal India Limited) started open cast coal mining in the Ib Valley since 1985 acquiring 926.6 hectares of land. It prepared a resettlement and rehabilitation policy of its own for those who have been forcibly displaced due to the mining operations. There are five open cast mining projects which have affected 18 villages and 1353 families. The Ib Thermal Power Station has been established in the Ib Valley coal mining region at Banaharpali ( now in Jharsuguda district ) by OPGC. 329 families were affected by the project in three villages out of which 146 families have been fully displaced. According to reports 169 families have been resettled in colonies.

In Orissa the whole village of Baragada has been taken as a case study as it is not only affected by the Hirakud Dam but also due to the ITPS of the OPGC. The villages are not physically displaced but their land has been acquired in both the instances and today the whole village residents are landless though their habitation (dwelling house) is intact. The villagers including the women have been forced to change 
their occupation due to land alienation. The irony is that the village has the Hirakud Dam reservoir on one side and the ITPS on the other but no electricity, no safe drinking water source and no irrigation facility for whatever marginal cultivation is done at the periphery of the village. The women of this village had been subjected to police atrocities and also jailed when they protested against the ITPS establishment in 1990.

The second case study is Munika Chandan, wife of Ramaddin Chandan. The Chandan family, displaced due to ITPS, has been residing in the Adhapara camp village meant for Hirakud oustees. This family was ousted from the Banaharpali village in 1992 for the establishment of IPTS. The police force forcibly ousted the family from their original dwelling. The houses were bulldozed. The women including the children were cordoned off and all the livestock, jewellery, puja goods and Mahalakshmi idol were ransacked. As the present location is not a resettlement camp for the ITPS displaced, the Chandan family is living on borrowed space. Their compensation due to land acquisition in Banaharpali (original village) is still pending.

Gouri Kumbhar, widow of Sukhbasi (landless), was displaced due to the MCL mining and is presently residing in the Sri Jaganath resettlement colony. Earlier in the original village, she was able to sustain a living out of the forest produce, or the common property resource items such as mahula, sal leaves, jhadu sticks, etc. Today she just does not have any opportunity to earn and thus is totally dependent on her son. As she was landless, in the compensation package she has just got a 6 decimal land in the resettlement colony in lieu of the house lost. Due to penury she has still not been able to construct a house in the land allotted and presently stays in the market complex built in the resettlement colony.

Balmati Bag, widow (landowner), was displaced due to the coal mining of MCL, she has got a 10 decimal land in the resettlement colony (Sri Ganesh nagar) for the house lost and Rs 50,000 for the land lost due to the project. She lived with her husband and his three other brothers in the village. Her husband's eldest brother got a job in the MCL. Her husband did not get a job and her son was young then. Today she has lost her husband and the son has grown up. As the joint family has broken to nuclear families (separate kitchen), her son was promised a job in the company but till date it has not come through. Now her son is a vegetable vendor. Balmati herself has lost her occupation and source of livelihood in the resettlement colony. It offers no scope for any kind of livelihood for her and today she is totally dependant on her son's income. She feels a burden on her heart on how to lead the days to come.

Kamala Bhua, aged about 65 years, presently residing in the Adhapara camp village, was displaced due to Hirakud Dam. She was barely 10 years old when all her family members had to leave their homes carrying just a trunk on their heads. Her village was fully submerged due to the dam and they were not in a position to carry all their belongings. They all settled in the Adhapara camp. She grew up and married to a boy from a family staying in the same camp, who, too was displaced. Her parents are dead and her brother too is dead. She has faint memories of her original village but she was old enough to remember the hard ship that her family had to endure in the new location. The whole area was a jungle and there was no food or water available for days. It was a long time before her mother could set up a kitchen and start cooking. She as a young girl went to the jungle to look for edible fruits and roots. Today she has settled in her life with her sons and daughters. But disaster struck again when the OPGC was acquiring land for the ITPS. The Adhapara camp was again to be displaced. The villagers, both men and women, got together and protested. Kamal took a lead in the protest and she along with 50 other women was put in the Sambalpur district HQ jail for more than a month. The villagers courted arrested and the administration was not in a position to tackle such a law-and-order situation. Finally the ITPS were forced to abandon this camp village for its acquisition. Kamala is cynical when one talks about displacement and about the usefulness for recording her narratives. 


\section{Gujarat}

The next part of the research work was done in Gujarat. The violence of February-May 2002 against the Muslim minority community in Gujarat assumed ominous proportions in its reach and intensity. Women were the worst sufferers due to this pogrom. In many cases, they were brutally tortured and raped. Even the children were not spared and burnt alive. Means of living and livelihood of the minority people were systematically destroyed. Shrines and places of worship of the minority community were desecrated and damaged. Social and economic boycott of the community was encouraged. The voices of these displaced persons give us an idea of the situation of insecurity they had to go through and probably some of them are still going through.

Fieldwork was concentrated mainly on Ahmedabad and Vadodara as most of the displaced persons are still struggling to come out of the situation of insecurity around these cities. As part of the report the researchers said that the camps for the displaced persons may not exist any more, but the displaced in the semi-urban areas and district towns have not yet been able to return to their original homes. She says that "Muslims from all social strata, rich and poor, were the prime targets for the state-sponsored pogrom unleashed in different parts of Gujarat." According to them places like Narora Patiya and Chamanpura in Ahmedabad were worst affected. Mostly people stayed in camps provided by NGOs. A few stayed in government camps. All these camps were devoid of basic amenities such as safe drinking water, medical and sanitation facilities. Today the camps are all disbanded but people are living in ghettoised clusters. This is mainly due to the perception of the victims that they were attacked because they were living away from their communities.

Except Jamalpur of Ahmedabad, which is the old Muslim dominated area situated at the western part of Sabarmati, the places visited in the suburb of Ahmedabad, are semi-urban areas newly created for the rehabilitation of the Muslim displaced persons. All the respondents, in Faizal Park, Batwa were women and displaced from their original home at Narora Patiya. In Faizal Park these displaced persons used to live in a ghetto. The respondents repeatedly mentioned the name of sansthas (organisations) like Gujarat Relief Committee, which helped each of them to get the one-room house constructed under the same roof in a continuous way, separated by the walls at very nominal cost.

In Ektanagar, the place adjacent to Faizal Park of Batwa, almost 120 -125 families were living together in a three-storied construction where one room with some small area for kitchen and bathroom was allotted for each of the displaced families and these rooms were connected by a long veranda. Thirteen respondents in Ektanagar were interviewed, who said that the NGOs like Action Aid, Islamic Relief Committee and Amun Samudaya assisted them to buy the land, make the constructions and distribute the materials for the livelihood of these hapless families respectively. Most of the respondents of this area were suffering from severe skin diseases, as they had no other option but to work at the Kaju factory nearby for their survival.

While the majority living in Ektanagar came from the camp located at Batwa, most of the rehabilitated families living in the area surrounding Bombay Hotel came directly from Shah Alam Camp, which was the biggest makeshift camp created at the height of the communal violence of 2002. Similarly, the places where research was undertaken in Halol, Kalol and Godhra are predominantly rural in its nature, newly created for the Muslim displaced persons. In Navinagri of Godhra six persons were interviewed, who after their displacement from their villages at the time of violence of 2002, took shelter in the Godhra camp and with the help of the camp authorities were rehabilitated in this area. In Kalol there is a newly built colony named Kashimabag Housing Society near the main bus stand. In this society all the 
respondents were female and widows. They described vividly how their husbands became shahid during the violence. Respondents from Godhra, Halol and Kalol explained that the NGOs like Jan Vikas Sanstha, Islamic Relief Committee, Amun samudaya, Jagruti, and SEWA (Lukhnow) contributed a lot to resettle their lives.

Almost all of the respondents were critical about the government help. They said that initially the government did nothing to save their lives during the turmoil and when they were lucky to find shelter in the camps established by the community organisers with the help of the NGOs they only received some bad quality grains and vegetables from the state government. In this context, it is to be kept in mind that, according to one estimate, initially 1,50,000 (the government figure was much less) people were displaced and took shelter in 121 relief camps (mostly set up by the community organisations and NGOs) located in and around the affected areas. Even after the killing and displacement of many, the Gujarat government refused to provide any assistance to these hapless people. In short, the basic humanitarian concerns of these displaced persons were entirely ignored. Moreover, respondents claimed that, while some of them got a sum of Rs 1250-2500 as compensation to re-built their homes, many of them did not receive any help from the government for the loss of their properties. In fact, those who received government help also expressed their grievances by saying that, the amount they got was negligible in terms of their loss.

The widow respondents of Kashimabag told that the government granted Rs 1,50,000 for the death of a person during the communal violence and they as the family members of the dead person received onethird of this amount in cash and rest in the form of government bonds. The release of the money for the death compensation depended on the production of a death certificate, which often became difficult for these people to deliver. As a result, some of the families of the same neighbourhood did not even receive any compensation from the government. However, altogether eight widow respondents got the death compensation of Rs 1,50,000, of which Rs 50,000 was in cash and the remaining amount in government bonds, against which they are receiving Rs 500 monthly.

From the extensive evidences recorded it is clear that the Muslims from all social strata, rich and poor, were the prime targets for the state-sponsored pogrom unleashed in different parts of Gujarat. Only in a few cases, some Hindu establishments were also targeted in the cities of Ahmedabad and Vadodara..

In the early phase of their displacement, the victims were hesitant to come forward to register cases against their perpetrators who had political connections. In many cases, the police intimidated them to withdraw their cases. In the relief camps, hardly any state assistance was provided for the victims. The victims could not even register their claims for compensation on account of deaths of their family members or destruction of their property. Many who had migrated from other areas to relief camps, were simply too terrified to return to their homes and file cases or claims.

Many respondents noticed that the Hindu houses were marked out using the saffron flags, or pictures of Ram and Hanuman, or with crosses in their Muslim dominated chalis before the attacks of the Hindu tola on them. Not only that, they were rigorously interrogated by a team of government officials in the name of the 'BPL' (Below Poverty Line) survey, which was conducted six months before the attacks and since then they became the targets of the Hindu attacks, they claimed.

Some respondents repeatedly mentioned that, in their places several training camps were conducted by the Bajrang Dal and the VHP, backed by the RSS and supported by democratically elected representatives from the ruling BJP. The camps were often conducted in temples. The aim was to generate intense hatred against Muslims painted as 'the enemy'. The trishuls and swords were largely used during the time of violence in these places. 
Women and young girls were targeted brutally, as were children. Rape became the means of the systematic violence. While sharing their nightmare experiences with me some of the women victims have described how the terrorised women of their own areas were forced to parade naked through the neighbourhood; victims were urinated upon, before being finally cut to pieces and burnt and how the whole episode of killing left an ineradicable imprint on the minds of the survivors, who saw their near and loved ones killed and, that too, in such a fashion.

\section{Jammu and Kashmir}

The other area where fieldwork was conducted was in Jammu and Kashmir mainly in the militancy affected areas and near the Line of Control, particularly in villages affected due to military operations by the Indian forces. In 2001-02 Operation Parakram triggered the biggest ever displacement from the borders, most of the people having been left homeless for over a year. However, displacement has been a common feature for villagers living close to the international border and the disputed line of control since 1947-48 due to frequent hostility between Indian and Pakistani forces on the two sides of the dividing line. The plight of the people living in villages up north along the line of control is much worse. They are not only caught in the crossfire between the Indian and Pakistani forces but also between militants and Indian security forces. The fencing operation, that was taken up in a big way by the Indian army after the ceasefire between India and Pakistan was announced, has also played havoc with the lives of the people on the international border and the line of control, more with the latter where at least 45 villages have been totally fenced out. The research team visited border villages of Akhnoor (Garar, Samwa, Chapriyal and Sainth) and Poonch (Birhuti, Degwar and Kerni), besides two camps for displaced persons at Akhnoor. The findings are as follows:

At least 80 per cent of the people who have returned to their villages are dispossessed of their agricultural lands. It is important to point out that this area is agriculturally rich and farming has been the mainstay. Prior to 1999, the farmers were tilling and farming in the fields right until the zero-line, barring a fraction of agricultural land that was heavily mined during the 1971 war. The mines were never removed and till 1998, the people affected by the 1971 mining were regularly receiving compensation for the same. No compensation for any kind of mining has been paid in the last six years. The villagers have no access to the mined fields, which are also fenced out by the recent fencing operations on the borders. The land across the fence, which is apparently also the traditional pasture ground for the cattle, is under army surveillance. As per timings specified by the army, the gates are opened to allow the villagers to cut grass for fodder of the animals or allow the animals to graze around at their own risk. Several cattle-heads have become casualties due to the mines and the fencing restrictions pose their own kinds of problems. For housing needs, the people are being paid Rs 15,000 to Rs 25,000 per family which most of them find inadequate.

In the camps, major problems are still schooling and health related. Their original villages are $20 \mathrm{~km}$ away and traveling to and fro on a regular basis is not an easy job in overcrowded buses and other public transport. Most of these camp inmates are still putting up in tented accommodation, some of them having built shacks for better protection. The area witnesses frequent high velocity winds, storms and rains, during which life in tents can be a real ordeal. In one of the existing camps at Naiwalla, the structures, constructed by the displaced persons, in tents on the land identified for the camp, were demolished by the local administration in the first week of August 2005. Their electricity and water supply were discontinued. The matter has become a major bone of contention not just between the displaced persons and the government, but also the two major political parties in the area - Congress and BJP. Besides, land mafia, grabbing and encroaching on the land with the patronage of some officials is also found to be another reason. The Centre has announced a package of Rs 78 crore for the border people from just these 78 villages, out of which Rs 22 crore is already released. Much of the money is likely to be spent on constructing permanent safe shelters for these villagers, on the reconstruction of their houses, (an amount which has already been disbursed but found inadequate), schools and healthcare infrastructure. These 
people till last year were receiving some relief in terms of rations and meager cash doles. Some months back, the government announced extension of free rations for a period of another year, ending September 2005. Most villagers, both those living on the camps and in the villages, said that they were not receiving this ration or they had received it only for two months.

In the twin border districts of Rajouri and Poonch, the situation in 45 border villages is alarming. They have been totally fenced out in the recent fencing operations by the Indian army (2004) and their lives are under total control of the army, the virtual absence of the civil administration in these areas adding to their woes. The fencing, which is 6-7 kilometers inside the Line of Control restricts their movement and they are totally isolated from rest of the country. And, that alone is not their sole concern. As per a central government plan in 2001 to relocate the villages from the zero-line to the interiors, Kerni, a village comprising 106 families, in Poonch tehsil becoming the first target, cluster colonies have now come up in most of these 45 villages. The cluster colonies are located 4-6 kilometers distance from the zero line as well as their homes and fields.

The fencing and cluster colonies have compounded the problems of the people who have already tasted the bitter pill of government neglect, as well as poor or negligible roads, health and education facilities. The people's lives ar e under army's surveillance all the time and they are expected to be back before dusk in these cluster colonies. They go every morning to their fields and homes, which may be a good one and half hours walk for some, work the entire day and must report back in the cluster colonies by the evening. The timings are arbitrary as per the whims of the army units in the area - in some cases, the villagers are expected to be back by 4 PM. The only job that the civil administration did was to allot small pieces of land for construction of one-room tenements per family in these cluster colonies for the people and announce Rs 1 lakh each family for the construction of the same. The full payment has not been released in most cases and some people have regretted the level of corruption involved, or the disregard for the latest census, depriving some of these people of any funds. The health facilities are poor and educational facilities, barring a few villages, are not quite up to the mark. The villagers are totally dependant on the army for their needs and it all depends on the whims of the unit officers posted there to help them with healthcare or educational facilities.

Among the border migrants Lajwanti Devi, a 75-years-old widow of an ex-serviceman, was interviewed. Such people form part of a considerable chunk of population of border residents, who are living in the twilight zone of life. With most of them widowed, these aged women and sometimes men do not even have the consolatory support of their spouses to tide them through the desperation that marks their life as border migrants.

Like most border villagers of her age, Lajwanti has seen four wars between India and Pakistan with her husband by her side, who died a few years ago. However, being a border resident in Pallanwala sector, Lajwanti is not afraid to lose anything any more.

This fearlessness comes not from a brave heart, although, the community of border residents practice more patience than abject bravery, it comes from the simple fact that she has little to lose now, in case a fifth war takes place.

Lajwanti has nothing left in her life. She lost her husband, an ex-serviceman, a few years ago. The couple was already childless. The constant rumbling, booming and pelting of war guns also did not give any chance to the rustic pair to build something of a property.

Therefore, when Kargil war began in 1999, the guns spoke, once again, on both sides of the Line of Control (LoC) in Akhnoor and the verdict was out that the 6, 072 families living in the 28 villages located in the vicinity of LoC have to leave. Overnight, the border residents became border migrants and came to 
live with their relatives, friends, even acquaintances, since, like always, the government and local administration took time to "react."

Living alone in her two-room house in Sainth village, one of the worst affected during the cross-border conflict, Lajwanti also took flight along with her neighbours, leaving behind her house, furniture, clothes, taking with her some cash, little jewellery and a lifetime of memories. Once, the tents had been erected at four different locations around Akhnoor, the border migrants moved in to settle down to a new pace of life, little knowing that these tents were going to be there home for the coming five-and-a-half years.

Like the rest of her ilk, Lajwanti also moved into one of the tents at Naiwala migrant camp, located in close proximity to two other camps, Devipur and Puloon. It was not the first time for the border people to leave everything and start afresh, so, life began to settle to the changed pace and quality, post-disturbance. Since the majority of the migrants had traveled to these camps with only the clothes on them, the government provided them with ration and cash relief, besides regular supply of water and electricity, for which basic infrastructure was also installed by the respective departments. A few health centers were also opened up at the camps and schools, which were closed down in their native villages; these were shifted to these camps so that children could continue their education but that was it. After being driven out of their homes, the border men, women and children nurtured the dream of returning to their villages one day, when everything would be fine and peace would, once again, return to the land. They waited while the bullets were exchanged across the International Border (IB) and LoC between troops of India and Pakistan. They waited while casualties mounted on both sides and the land, including that part, which yielded food for empty stomachs, was littered with dead bodies or mutilated limbs, instead of paddy, wheat, maize and sugarcane. The wait might finally have been over with the declaration of ceasefire between India and Pakistan on the intervening night of November 25 and 26 in 2003. Alas! It ended for them in the most unceremonious terms about eight and a half months later in August 2004. This happened with the state government suddenly deciding to take back all the government schools to their native villages, since it thought that border migrants could now start living there again.

The only problem was that the houses were damaged, most of them razed to ground, there was no land to cultivate, most of that having been taken over by minefields, there was no electricity or water supply, most of it damaged in the crossfire and, above all, there was no sense of security. The border people, who have seen and heard the guns more than the rest of the citizens of Jammu and Kashmir, did not trust the ceasefire between India and Pakistan, therefore, they were not too keen to go back unless provided with assurance from their elected representatives. The assurance never came but what came, instead, were orders, more like decrees, which forced the migrants to vacate the tents and go back to their houses.

After much hue and cry was raised, the Centre came to senses and announced a relief and rehabilitation package for the border migrants, which ran into crores.

Gradually, the money was distributed, infrastructure raised where it was possible, and border families started trickling back to their homes, in pursuit of a normal life that existed in the pre-war days. The rehabilitation work started in about 21 out of 28 border villages in Khour block with the rest of the villages having been damaged beyond repair and there being no way the residents of these villages could go back, at least, presently.

Lajwanti's village, Sainth, was one of these. So, along with the rest of villagers, she stayed put in the Naiwala camp even as at Devipur camp, just next to Naiwala, tents were being pulled off till all the migrants had returned home.

Then, quite suddenly in August 2005, the district administration came to their camp one evening and stopped the power and water supply to the camp in wake of an anti-encroachment drive. The fact of the matter was that some of the border migrants had erected concrete structures inside the camp. The camp is 
located on land taken on lease by the government from private parties. Construction of concrete structures obviously miffed the administration, which retaliated in the most undemocratic manner by pouncing on the hapless migrants one evening and running bulldozers over the structures indiscriminately over bricks and humans. The disconnected supply of water and electricity added to the woes of the displaced families who were already bearing the brunt of fending for themselves since the government had also stopped cash relief to them since September last.

Sitting outside her tent, on a simmering afternoon, Lajwanti was enjoying her afternoon treat, which consisted of a few pale and dry cucumbers. While slicing the cucumbers into a thali, Lajwanti tells, 'Ever since I was married and lived in Sainth, it has only been guns and destruction for us. I have seen with my eyes and heard with my ears the noise caused by firing. There was no way we could save ourselves even if we stayed inside our homes."

Therefore, Lajwanti and her husband had to run every time the guns roared and that happened frequently in the years since independence and subsequent accession of Jammu and Kashmir to India.

Once, she was in the migrant camp, life settled down to a droning monotony thanks to the drudgery of camp life. Government provided the basics like water, electricity, ration and financial assistance. Therefore, there was little to worry besides when to return home and this was the only thought that occupied the free hours of Lajwanti. Then, there were the neighbours, who continued to share life just like the old days back home. The only difference was that for once, there was little else to do except to share the pain and anguish of the present life.

Since Lajwanti lived alone, she had little household work to do, notwithstanding the living space of a single tent that she was occupying. Every afternoon, when the women become free from their daily chores, they used to gather in front of Lajwanti's tent and settle down on a few cots available to take stock of each other's lives, what the children were doing, who was to be married off and what would be government's next decision.

Among all these "occupied" women, Lajwanti felt like she had nothing and no one to look forward to in life but that remained a fleeting thought for her optimistic disposition.

While recalling her earlier camp life alone, Lajwanti says, 'While women around me were usually kept busy by their families, I could only sit around and watch with nothing much to do. Earlier, it used to bother me because I have never been the kind to sit with hand over hand. It felt like I had my hands tied on my back and no one could untie them. However, gradually, I came to terms with the reality and credit also goes to my neighbours in the camp, who come to spend time with me whenever possible."

The only regret of Lajwanti is that the government does not think about the people of her age.

Right from food, water, electricity to medicines and clothes, the border migrants, widows and widowers, who have no family comfort to call their own, are forced to fend for themselves. The only help they get from the government is the relief and cash assistance, which does not account for much since it is not regularly available to them. Sometimes, it used to be months before Lajwanti and others like her were able to collect their stipulated amount of ration and money. Of those days, Lajwanti says, "The flour, which we got from the ration depot, was usually infested with worms. I had to pick up all the worms from the flour before I could use it to make dough. Even then, it was tasteless and I was not able to eat more than one chapatti made from it. It further reminded me of my life back in my village where I was, at least, able to eat two square meals of decent quality." 
The food, however, was not the only concern of this septuagenarian, who also had to counter sickness more than once while she lived at Naiwala camp.

With the basic health facilities altogether absent from the scene, Lajwanti had to rely on quacks, who were readily available around the camp and catered to most of the migrant population. She told, 'During initial days, when I fell ill, I had to board the bus alone and go to Akhnoor, which is about $15 \mathrm{~km}$ away, and visit the government hospital there for treatment. It was not only a tedious job but cost a lot of money as well, if only for transport." Gradually, when Lajwanti started remaining sick, she stopped going to the government hospital altogether to save the meager sum of cash relief that she received from government. By doing so, she became more and more dependent on the quacks around, who administered sub-standard medicines and other makeshift treatments to her.

Living in a tattered tent, with just meager belongings, Lajwanti slowly slipped into a trance-like state, where she could go on for days without talking to anyone around her, not that there was any family, only neighbours from the village.

Lajwanti is not angry anymore while talking of the indifferent attitude of authorities towards the border migrants nor does she spew venom while speaking of the MLA for whom she voted in the last elections. Ask her whether she feels any pain or anguish on her present state of life, she says, with a contented smile, 'My husband and I were never interested in accumulating huge wealth, although my husband, an ex-serviceman, was a very hardworking man, who spent long working hours in the field. I assisted him too. However, I feel sorry for our young children, who have nothing to lean back on since their previous generations have been beaten down by the hardships facing them in the border villages."

Chewing on the cucumber, which she has cut for herself, Lajwanti reminisces, "Nothing is forever in life nor is anything stationery. I have learnt to live life within whatever means I have but government should have thought about the fact that a whole nasl (generation) of border residents is wasting away." Though she comes across as fairly optimistic, Lajwanti is awaiting her death more than the return to her village because of her own reasons about which, she says, 'Even if I go back to my village, there is n o one with whom I would share my house. I will be alone, once again. That is why, I would prefer to be dead than to return home because, at least, then, I would be with my husband up there."

Lajwanti portrays the situation of the older generation of IDPs. It clearly reveals that though all IDPs are vulnerable there are some who are more vulnerable than the rest. Being a woman, a widow and an aged person increases Lajwanti's vulnerabilities. The state should have made separate policies to offer rehabilitation and care to such people but because there are no legal mechanisms the state treats them as collateral damages.

The situation of IDPs taken cumulatively from these four cases presents a gloomy picture. Quantitative research brings out that about 60 per cent of all IDPs interviewed are illiterate. About 56 per cent had more than two children in their family. An overwhelming number (45.6 per cent) were in the domestic and agricultural sector. About 59 percent of IDP families interviewed earned less than Rs 1000 (25 dollars) a month. More than 60 per cent of the IDPs were displaced for over five years. About 55 per cent of the respondents stated that they received no material help from government or otherwise. Only 13.1 per cent responded that they received some help from the government. About 78.6 per cent of the respondents stated that they had poor health. Unlike in other countries of South Asia, in India only 2.9 per cent respondents said that their children were recruited in the armed forces. 84 per cent respondents stated no support was given to either the elderly or the pregnant. An overwhelming problem in the region remains economic (50 per cent). About 73.3 per cent responded that they had no hope of going back to their original place of living. Only one respondent said that she was aware of the UN Guiding Principles. Only 5.3 percent of the respondents had any hope for improvement in their condition due to policy 
mechanisms. However, 24.3 per cent of the respondents said that policies should address the security needs of IDPs.

Cross tabulation showed that of the total number of 85 respondents displaced due to armed conflict 73 were displaced for more than five years. People who are displaced due to armed conflict had much higher rate of being displaced more than once as compared to those displaced due to projects. As many as 55 of those displaced due to armed conflict said that they still suffered from the lack of security, and 48 of them said policy makers should work towards greater security for the displaced. The majority of the victims of developmental projects suffered from economic problems. What is clear from this research is that people displaced due to armed conflict suffered from a sense of insecurity and those displaced due to development projects suffered greatly from economic problems.

\section{FREQUENCY TABLES}

\subsection{Household Head}

\begin{tabular}{|l|c|c|}
\hline & No. of Respondents & Percentage \\
\hline Yes & 95 & 46.1 \\
\hline No & 111 & 53.6 \\
\hline No comment & 0 & 0.0 \\
\hline Not applicable & 0 & 0.0 \\
\hline Total & 206 & 100 \\
\hline
\end{tabular}

\subsection{Age}

\begin{tabular}{|l|c|c|}
\hline & No. of Respondents & Percentage \\
\hline 14-24 Yrs. & 23 & 11.2 \\
\hline $25-39$ Yrs. & 72 & 35.0 \\
\hline $40-59$ Yrs. & 65 & 31.6 \\
\hline $60 \&$ above & 46 & 22.3 \\
\hline Total & 206 & 100.0 \\
\hline
\end{tabular}

\subsection{Gender Status}

\begin{tabular}{|l|c|c|}
\hline & No. of Respondents & Percentage \\
\hline Female & 141 & 68.4 \\
\hline
\end{tabular}




\begin{tabular}{|l|c|c|}
\hline Male & 65 & 31.6 \\
\hline Others & 0 & 0.0 \\
\hline Total & 206 & 100.0 \\
\hline
\end{tabular}

\subsection{Literacy Level}

\begin{tabular}{|l|c|c|}
\hline & No. of Respondents & Percentage \\
\hline Illiterate & 123 & 59.7 \\
\hline Can only read & 10 & 4.9 \\
\hline Read and write both & 15 & 7.3 \\
\hline Till primary & 19 & 9.2 \\
\hline Till high school & 30 & 14.6 \\
\hline Above school & 8 & 3.9 \\
\hline No comment & 1 & 0.5 \\
\hline Total & 206 & 100.0 \\
\hline
\end{tabular}

\subsection{Marital Status}

\begin{tabular}{|l|c|c|}
\hline & No. of Respondents & Percentage \\
\hline Married & 153 & 74.3 \\
\hline Unmarried & 16 & 7.8 \\
\hline Divorced / Separated & 3 & 1.5 \\
\hline Widow / Widower & 34 & 16.5 \\
\hline Total & 206 & 100.0 \\
\hline
\end{tabular}

\subsection{Family Members}

\begin{tabular}{|l|l|l|}
\hline & No. of Respondents & Percentage \\
\hline Below 5 & 59 & 28.6 \\
\hline Between 5-8 & 103 & 50.0 \\
\hline
\end{tabular}




\begin{tabular}{|l|l|l|}
\hline Above 5 & 44 & 21.4 \\
\hline Total & 206 & 100.0 \\
\hline
\end{tabular}

\subsection{Adult Members in Family}

\begin{tabular}{|l|l|l|}
\hline & No. of Respondents & Percentage \\
\hline Below 2 & 29 & 14.1 \\
\hline Between 2-5 & 134 & 65.0 \\
\hline Above 5 & 43 & 20.9 \\
\hline Total & 206 & 100.0 \\
\hline
\end{tabular}

\subsection{Children in Family}

\begin{tabular}{|l|c|c|}
\hline & No. of Respondents & Percentage \\
\hline Below 2 & 38 & 18.4 \\
\hline Between 2-5 & 117 & 56.1 \\
\hline Above 5 & 14 & 6.8 \\
\hline Not applicable & 37 & 18.3 \\
\hline Total & 206 & 100.0 \\
\hline
\end{tabular}

\subsection{Current Occupation}

\begin{tabular}{|l|c|c|}
\hline & No. of Respondents & Percentage \\
\hline Domestic / Agricultural Labour & 94 & 45.6 \\
\hline Industrial Labour & 10 & 4.9 \\
\hline Self Trade & 9 & 4.4 \\
\hline Others & 89 & 43.2 \\
\hline Multiple answers & 2 & 1.0 \\
\hline Not applicable & 2 & 1.0 \\
\hline Total & 206 & 100.0 \\
\hline
\end{tabular}




\subsection{Current Monthly Income}

\begin{tabular}{|l|c|c|}
\hline & No. of Respondents & Percentage \\
\hline No Income & 60 & 29.1 \\
\hline Below Rs. 1000 & 110 & 53.4 \\
\hline Between Rs. 1000-2000 & 20 & 9.7 \\
\hline Between Rs. 2000-3000 & 5 & 2.4 \\
\hline Above Rs. 3000 & 7 & 3.4 \\
\hline No comment & 4 & 1.9 \\
\hline Total & 206 & 100.0 \\
\hline
\end{tabular}

\subsection{Displacement Reasons}

\begin{tabular}{|l|c|c|}
\hline & No. of Respondents & Percentage \\
\hline Natural Disaster & 1 & 0.5 \\
\hline Development Project & 48 & 23.3 \\
\hline Armed Conflict & 85 & 41.3 \\
\hline Army Occupation & 11 & 5.3 \\
\hline Others & 49 & 23.8 \\
\hline Multiple answers & 9 & 4.4 \\
\hline No comment & 3 & 1.5 \\
\hline Total & 206 & 100.0 \\
\hline
\end{tabular}

\subsection{Years in Displacement Situation}

\begin{tabular}{|l|c|c|}
\hline & No. of Respondents & Percentage \\
\hline One year or less & 1 & 0.5 \\
\hline Between 1-3 Years & 8 & 3.9 \\
\hline Between 3-5 Years & 72 & 35.0 \\
\hline
\end{tabular}




\begin{tabular}{|l|c|c|}
\hline Above 5 Years & 124 & 60.2 \\
\hline No comment & 1 & 0.5 \\
\hline Total & 206 & 100.0 \\
\hline
\end{tabular}

\subsection{Directly journeyed from Original to Current Place}

\begin{tabular}{|l|c|c|}
\hline & No. of respondents & Percentage \\
\hline Yes & 40 & 19.4 \\
\hline No & 165 & 80.1 \\
\hline No comment & 1 & 0.5 \\
\hline Total & 206 & 100.0 \\
\hline
\end{tabular}

\subsection{Single / Multiple Displacement}

\begin{tabular}{|l|c|c|}
\hline & No. of Respondents & Percentage \\
\hline More than once & 96 & 46.6 \\
\hline No & 72 & 35.0 \\
\hline No comment & 38 & 18.5 \\
\hline Total & 206 & 100.0 \\
\hline
\end{tabular}

\subsection{Material Support Available}

\begin{tabular}{|l|c|c|}
\hline & No. of Respondents & Percentage \\
\hline Yes & 91 & 44.2 \\
\hline No & 114 & 55.3 \\
\hline No comment & 1 & 0.5 \\
\hline Total & 206 & 100.0 \\
\hline
\end{tabular}

\subsection{Support Provider}

\begin{tabular}{|l|l|l|}
\hline & No. of Respondents & Percentage \\
\hline
\end{tabular}




\begin{tabular}{|l|c|c|}
\hline Government & 27 & 13.1 \\
\hline NGO/INGO & 19 & 9.2 \\
\hline Others & 49 & 23.8 \\
\hline Multiple answers & 3 & 1.5 \\
\hline No comment & 4 & 1.9 \\
\hline Not applicable & 104 & 50.5 \\
\hline Total & 206 & 100.0 \\
\hline
\end{tabular}

\subsection{Type of Support}

\begin{tabular}{|l|c|c|}
\hline & No. of Respondents & Percentage \\
\hline Economic Support & 5 & 2.4 \\
\hline Shelter & 16 & 7.8 \\
\hline Food & 25 & 12.1 \\
\hline Health & 0 & 0.0 \\
\hline Psychological & 1 & 0.5 \\
\hline Repatriation related & 0 & 0.0 \\
\hline Others & 0 & 0.0 \\
\hline Multiple support & 10 & 4.9 \\
\hline No comment & 56 & 27.2 \\
\hline Not applicable & 58 & 2.4 \\
\hline Total & 206 & 42.7 \\
\hline
\end{tabular}

\subsection{Educational Support for Children}

\begin{tabular}{|l|c|c|}
\hline & No. of Respondents & Percentage \\
\hline Yes & 74 & 35.9 \\
\hline
\end{tabular}




\begin{tabular}{|l|c|c|}
\hline No & 114 & 55.3 \\
\hline Not applicable & 18 & 8.7 \\
\hline Total & 206 & 100.0 \\
\hline
\end{tabular}

\subsection{Do Children Work Anywhere?}

\begin{tabular}{|l|c|c|}
\hline & No. of Respondents & Percentage \\
\hline Yes & 46 & 22.3 \\
\hline No & 137 & 66.5 \\
\hline Not applicable & 23 & 11.7 \\
\hline Total & 206 & 100.0 \\
\hline
\end{tabular}

\subsection{Job Nature of Children}

\begin{tabular}{|l|c|c|}
\hline & No. of Respondents & Percentage \\
\hline Domestic Labour & 11 & 5.3 \\
\hline Industrial Labour & 30 & 14.6 \\
\hline Others & 8 & 3.9 \\
\hline Not applicable & 157 & 76.2 \\
\hline Total & 206 & 100.0 \\
\hline
\end{tabular}

5.21 Health Condition of Family Members

\begin{tabular}{|l|c|c|}
\hline & No. of Respondents & Percentage \\
\hline Good & 35 & 17.0 \\
\hline Better & 7 & 3.4 \\
\hline Poor & 162 & 78.6 \\
\hline No comment & 1 & 0.5 \\
\hline Not applicable & 1 & 0.5 \\
\hline Total & 206 & 100.0 \\
\hline
\end{tabular}




\subsection{Medical Assistance in Need}

\begin{tabular}{|l|c|c|}
\hline & No. of Respondents & Percentage \\
\hline Govt. Health Centre & 76 & 36.9 \\
\hline Private Clinic & 33 & 16.0 \\
\hline Ayurvedic Doctor & 1 & 0.5 \\
\hline NGO Supported Clinic & 22 & 10.7 \\
\hline Others & 57 & 27.7 \\
\hline Multiple answers & 5 & 2.4 \\
\hline No comment & 4 & 1.9 \\
\hline Not applicable & 8 & 100.0 \\
\hline Total & 206 & \\
\hline
\end{tabular}

\subsection{Recruitment of Children in Armed Forces}

\begin{tabular}{|l|c|c|}
\hline & No. of Respondents & Percentage \\
\hline Yes & 6 & 2.9 \\
\hline No & 161 & 78.2 \\
\hline Not applicable & 39 & 18.9 \\
\hline Total & 206 & 100.0 \\
\hline
\end{tabular}

\subsection{Support to Pregnant / Elderly}

\begin{tabular}{|l|c|c|}
\hline & No. of Respondents & Percentage \\
\hline Yes & 27 & 13.1 \\
\hline No & 173 & 84.0 \\
\hline No comment & 1 & 0.5 \\
\hline Not applicable & 5 & 2.4 \\
\hline Total & 206 & 100.0 \\
\hline
\end{tabular}




\subsection{Major Concern of Pregnant / Elderly}

\begin{tabular}{|l|c|c|}
\hline & No. of Respondents & Percentage \\
\hline No allowance & 15 & 7.3 \\
\hline Lack of security & 10 & 4.9 \\
\hline Lack of basic amenities & 8 & 3.9 \\
\hline Others & 1 & 0.5 \\
\hline Multiple concern & 39 & 18.9 \\
\hline No comment & 5 & 2.4 \\
\hline Not applicable & 128 & 62.1 \\
\hline Total & 206 & 100.0 \\
\hline
\end{tabular}

\subsection{Problems Faces in the Region}

\begin{tabular}{|l|c|c|}
\hline & No. of Respondents & Percentage \\
\hline Social Discrimination & 4 & 1.9 \\
\hline Economic Problems & 103 & 50.0 \\
\hline Lack of Security & 59 & 28.6 \\
\hline Others & 15 & 7.3 \\
\hline Multiple answers & 23 & 11.2 \\
\hline No comment & 2 & 1.0 \\
\hline Total & 206 & 100.0 \\
\hline
\end{tabular}

\subsection{Restriction in Movement}

\begin{tabular}{|l|c|c|}
\hline & No. of Respondents & Percentage \\
\hline Yes & 34 & 16.5 \\
\hline No & 168 & 81.6 \\
\hline No comment & 4 & 1.9 \\
\hline
\end{tabular}




\begin{tabular}{|l|c|c|}
\hline Total & 206 & 100.0 \\
\hline
\end{tabular}

\subsection{Probability of Return}

\begin{tabular}{|l|c|c|}
\hline & No. of Respondents & Percentage \\
\hline Yes & 51 & 24.8 \\
\hline No & 151 & 73.3 \\
\hline No comment & 4 & 2.0 \\
\hline Total & 206 & 100.0 \\
\hline
\end{tabular}

\subsection{Agency Responsible For Return}

\begin{tabular}{|l|c|c|}
\hline & No. of Respondents & Percentage \\
\hline Government & 33 & 16.0 \\
\hline NGO/INGO & 4 & 1.9 \\
\hline Others & 10 & 4.9 \\
\hline Multiple answers & 2 & 1.0 \\
\hline No comment & 14 & 6.8 \\
\hline Not applicable & 143 & 69.4 \\
\hline Total & 206 & 100.0 \\
\hline
\end{tabular}

\subsection{Reasons For No Possibility of Return}

\begin{tabular}{|l|c|c|}
\hline & No. of Respondents & Percentage \\
\hline Socio -Political & 0 & 0.0 \\
\hline Loss of Livelihood & 55 & 26.7 \\
\hline Lack of security & 40 & 19.4 \\
\hline Others & 41 & 19.9 \\
\hline Multiple answers & 19 & 9.2 \\
\hline No comment & 8 & 3.9 \\
\hline
\end{tabular}




\begin{tabular}{|l|c|c|}
\hline Not applicable & 43 & 20.9 \\
\hline Total & 206 & 100.0 \\
\hline
\end{tabular}

\subsection{Knowledge of Policy Mechanisms for IDPs}

\begin{tabular}{|l|c|c|}
\hline & No. of Respondents & Percentage \\
\hline Valid Local (Yes) & 42 & 20.4 \\
\hline Local (No) & 105 & 51.0 \\
\hline National (Yes) & 1 & 0.5 \\
\hline No comment & 8 & 3.9 \\
\hline Not applicable & 50 & 24.3 \\
\hline Total & 206 & 100.0 \\
\hline
\end{tabular}

\subsection{Nature of Policy Mechanisms}

\begin{tabular}{|l|c|c|}
\hline & No. of Respondents & Percentage \\
\hline Law / Act & 0 & 0.0 \\
\hline Official Documents & 44 & 21.4 \\
\hline Media & 0 & 0.0 \\
\hline Others & 1 & 0.5 \\
\hline Multiple answers & 1 & 0.5 \\
\hline No comment & 1 & 0.5 \\
\hline Not applicable & 159 & 77.2 \\
\hline Total & 206 & 100.0 \\
\hline
\end{tabular}

\subsection{Knowledge of UN Guiding Principles}

\begin{tabular}{|l|c|c|}
\hline & No. of Respondents & Percentage \\
\hline Yes & 1 & 0.5 \\
\hline No & 143 & 69.4 \\
\hline
\end{tabular}




\begin{tabular}{|l|c|c|}
\hline No comment & 1 & 0.5 \\
\hline Not applicable & 61 & 29.6 \\
\hline Total & 206 & 100.0 \\
\hline
\end{tabular}

\subsection{Source of Knowledge About Policy Mechanisms}

\begin{tabular}{|l|c|c|}
\hline & No. of Respondents & Percentage \\
\hline Government representative & 0 & 0.0 \\
\hline NGO worker & 40 & 19.4 \\
\hline Friends & 1 & 0.5 \\
\hline Media & 3 & 0.5 \\
\hline Others & 1 & 1.5 \\
\hline No answers & 0 & 0.5 \\
\hline No comment & 160 & 0.0 \\
\hline Not applicable & 206 & 100.0 \\
\hline Total & & \\
\hline
\end{tabular}

\subsection{Improvement in Condition Due to Policy Mechanisms}

\begin{tabular}{|l|c|c|}
\hline & No. of Respondents & Percentage \\
\hline Yes & 11 & 5.3 \\
\hline No & 106 & 51.5 \\
\hline No comment & 5 & 2.4 \\
\hline Not applicable & 4 & 40.8 \\
\hline Total & 206 & 100.0 \\
\hline
\end{tabular}

\subsection{Any Suggestions To Agencies For IDPs Rehabilitation}

\begin{tabular}{|l|l|l|}
\hline & No. of Respondents & Percentage \\
\hline
\end{tabular}




\begin{tabular}{|l|c|c|}
\hline Yes & 159 & 77.2 \\
\hline No & 38 & 18.4 \\
\hline No comment & 9 & 4.4 \\
\hline Total & 206 & 100.0 \\
\hline
\end{tabular}

\subsection{Nature of Suggestions to Agencies}

\begin{tabular}{|l|c|c|}
\hline & No. of Respondents & Percentage \\
\hline Stop displacement at source & 8 & 3.9 \\
\hline Contain displacement through policy measures & 9 & 4.4 \\
\hline More social and economic assistance to be provided & 29 & 14.1 \\
\hline More security and care to be provided & 50 & 24.3 \\
\hline Appropriate compensation to be provided & 10 & 4.9 \\
\hline Steps towards early return of the IDPs & 7 & 3.4 \\
\hline Others & 7 & 3.4 \\
\hline Multiple answers & 40 & 19.4 \\
\hline No comment & 2 & 21.4 \\
\hline Not applicable & 44 & 100.0 \\
\hline Total & 206 & \\
\hline
\end{tabular}




\section{Some More Statistical Highlights}

\section{A. Does Gender Matter?}

\subsection{Problems Faced in the Region}

\begin{tabular}{|l|l|l|l|l|l|l|l|l|}
\hline \multirow{2}{*}{$\begin{array}{l}\text { Gender } \\
\text { Break Up }\end{array}$} & \multicolumn{9}{|c|}{ Problems Faced in the Region } \\
\cline { 2 - 9 } & $\begin{array}{l}\text { Soc. } \\
\text { Discrimination }\end{array}$ & $\begin{array}{l}\text { Economic } \\
\text { problems }\end{array}$ & $\begin{array}{l}\text { Lack of } \\
\text { security }\end{array}$ & Others & $\begin{array}{l}\text { Multiple } \\
\text { Answers }\end{array}$ & $\begin{array}{l}\text { No } \\
\text { comment }\end{array}$ & $\begin{array}{l}\text { Not } \\
\text { application }\end{array}$ & Total \\
\hline $\begin{array}{l}\text { Female } \\
\text { Male } \\
\text { Total }\end{array}$ & 28 & 146 & 43 & 12 & 52 & 3 & 3 & 287 \\
\cline { 2 - 9 } & 28 & 103 & 50 & 7 & 49 & 3 & 1 & 241 \\
\cline { 2 - 9 } & 56 & 249 & 93 & 19 & 101 & 6 & 4 & 528 \\
\hline
\end{tabular}

\subsection{Knowledge of Policy Mechanisms}

\begin{tabular}{|l|l|l|l|l|l|}
\hline \multirow{2}{*}{$\begin{array}{l}\text { Gender } \\
\text { Break Up }\end{array}$} & \multicolumn{5}{|c|}{ Knowledge of Policy Mechanisms } \\
\cline { 2 - 6 } & Multiple answer & Local (Yes) & Local (No) & $\begin{array}{l}\text { National } \\
\text { (Yes) }\end{array}$ & $\begin{array}{l}\text { International } \\
\text { (Yes) }\end{array}$ \\
\hline $\begin{array}{l}\text { Female } \\
\text { Male } \\
\text { Total }\end{array}$ & 80 & 33 & 101 & 1 & 1 \\
\cline { 2 - 6 } & 111 & 11 & 97 & & \\
\hline
\end{tabular}

\subsection{Knowledge of UN Guiding Principal}

\begin{tabular}{|l|l|l|l|l|l|}
\hline \multirow{2}{*}{$\begin{array}{l}\text { Gender } \\
\text { Break Up }\end{array}$} & \multicolumn{5}{|c|}{ Knowledge of UN Guiding Principles } \\
\cline { 2 - 6 } & Yes & No & No comment & $\begin{array}{l}\text { Not } \\
\text { applicable }\end{array}$ & Total \\
\hline $\begin{array}{l}\text { Female } \\
\text { Male } \\
\text { Total }\end{array}$ & 28 & 205 & 17 & 37 & 287 \\
\cline { 2 - 6 } & 47 & 149 & 20 & 25 & 241 \\
\hline
\end{tabular}


B. What are the Factors Influencing the Feelings of the IDP's on the Probability of their Return?

\subsection{Causes of Displacement as a Factor}

\begin{tabular}{|l|l|l|l|l|l|}
\hline \multirow{2}{*}{$\begin{array}{l}\text { Causes of } \\
\text { Displacement }\end{array}$} & \multicolumn{5}{|c|}{ Probability of Return } \\
\cline { 2 - 6 } & Yes & No & $\begin{array}{l}\text { No } \\
\text { comment }\end{array}$ & Not applicable & Total \\
\hline Natural disaster & & 41 & 2 & & 66 \\
$\begin{array}{l}\text { Aevelopment project } \\
\text { Armed conflict }\end{array}$ & 23 & 83 & & & 91 \\
\cline { 2 - 6 } $\begin{array}{l}\text { Army occupation } \\
\text { Others }\end{array}$ & 8 & 139 & 5 & 2 & 235 \\
\cline { 2 - 6 } $\begin{array}{l}\text { Nultiple answers } \\
\text { Not applicable }\end{array}$ & 7 & 27 & & & 34 \\
\cline { 2 - 6 } Total & 5 & 62 & 6 & 4 & 26 \\
\cline { 2 - 6 } & 14 & 8 & & & 2 \\
\cline { 2 - 6 } & & 1 & 1 & 6 & 528 \\
\cline { 2 - 6 } & 146 & 362 & 14 & & 1 \\
\hline
\end{tabular}

6.5 Duration of Displacement as a Factor

\begin{tabular}{|l|l|l|l|l|l|}
\hline \multirow{2}{*}{$\begin{array}{l}\text { Duration of } \\
\text { Displacement }\end{array}$} & \multicolumn{5}{|c|}{ Probability of Return } \\
\cline { 2 - 6 } & Yes & No & No comment & Not applicable & Total \\
\hline One year or less & 35 & 54 & 2 & 1 & 92 \\
\cline { 2 - 6 } $\begin{array}{l}\text { Between 1-3 yrs. } \\
\text { Between 3-5 yrs. }\end{array}$ & 11 & 34 & & 1 & 46 \\
\cline { 2 - 6 } $\begin{array}{l}\text { Above 5 years } \\
\text { No comment }\end{array}$ & 30 & 102 & 5 & 2 & 139 \\
\cline { 2 - 6 } Total & 70 & 172 & 6 & 2 & 250 \\
\cline { 2 - 6 } & 146 & 362 & 14 & 6 & 528 \\
\cline { 2 - 6 }
\end{tabular}

\subsection{Direct or Indirect Journey from the Habitual Place to Current Place as a Factor}

\begin{tabular}{|l|l|l|l|l|l|}
\hline Direct Journey from & \multicolumn{5}{|c|}{ Probability of Return } \\
\cline { 2 - 6 } the Habitual Place & Yes & No & No comment & Not applicable & Total \\
\hline \multirow{2}{*}{$\begin{array}{l}\text { Yes } \\
\text { No }\end{array}$} & 48 & 105 & 11 & & 164 \\
\cline { 2 - 6 } $\begin{array}{l}\text { No comment } \\
\text { Not applicable }\end{array}$ & 97 & 257 & 2 & 4 & 360 \\
\cline { 2 - 6 } Total & 1 & & 1 & & 2 \\
\cline { 2 - 6 } & 146 & 362 & 14 & 6 & 2 \\
\cline { 2 - 6 }
\end{tabular}




\section{Is Literacy Important?}

\subsection{Job Nature of Children}

\begin{tabular}{|c|c|c|c|c|c|c|c|}
\hline \multirow[b]{2}{*}{ Literacy Level } & \multicolumn{7}{|c|}{ Job Nature of Children } \\
\hline & $\begin{array}{l}\text { Domestic } \\
\text { Labour }\end{array}$ & $\begin{array}{l}\text { Industrial } \\
\text { Labour }\end{array}$ & Others & $\begin{array}{l}\text { Multiple } \\
\text { answer }\end{array}$ & $\begin{array}{l}\text { No } \\
\text { comment }\end{array}$ & $\begin{array}{l}\text { No } \\
\text { applicable }\end{array}$ & Total \\
\hline \multirow{8}{*}{$\begin{array}{l}\text { Illiterate } \\
\text { Can only read } \\
\text { Read \& write both } \\
\text { Educated till primary } \\
\text { Till high school } \\
\text { Above school level } \\
\text { No comment } \\
\text { Total }\end{array}$} & 19 & 244 & 11 & 1 & 2 & 164 & 221 \\
\hline & 2 & 4 & & & 1 & 30 & 37 \\
\hline & 3 & 5 & 6 & & & 59 & 73 \\
\hline & 4 & 10 & 6 & & & 59 & 79 \\
\hline & & 9 & 3 & & 2 & 81 & 95 \\
\hline & 1 & 1 & & & & 20 & 22 \\
\hline & & & & & & 1 & 1 \\
\hline & & & & & & 414 & 528 \\
\hline
\end{tabular}

\subsection{Health Condition of Family Members}

\begin{tabular}{|l|l|l|l|l|l|l|}
\hline \multirow{2}{*}{ Literacy Level } & \multicolumn{6}{|c|}{ Health Condition of Family Members } \\
\cline { 2 - 7 } & Good & Better & Poor & No comment & No applicable & Total \\
\hline Illiterate & 44 & 10 & 165 & 1 & 1 & 221 \\
\cline { 2 - 7 } Can only read & 8 & 4 & 25 & & & 37 \\
Read \& write both & 18 & 10 & 45 & & & 73 \\
\cline { 2 - 7 } $\begin{array}{l}\text { Educated till primary } \\
\text { Till high school }\end{array}$ & 23 & 7 & 48 & 1 & & 79 \\
\cline { 2 - 7 } $\begin{array}{l}\text { Above school level } \\
\text { No comment }\end{array}$ & 50 & 3 & 42 & & & 95 \\
\cline { 2 - 7 } Total & 7 & 2 & 13 & & & 22 \\
\cline { 2 - 7 } & 150 & 36 & 339 & 2 & 1 & 528 \\
\hline
\end{tabular}

\subsection{Problems Faced in the Region by the IDP's}

\begin{tabular}{|c|c|c|c|c|c|c|c|c|}
\hline \multirow[b]{2}{*}{ Literacy Level } & \multicolumn{8}{|c|}{ Problems Faced in the Region } \\
\hline & $\begin{array}{l}\text { Soc. } \\
\text { Discrimi- } \\
\text { nation }\end{array}$ & $\begin{array}{l}\text { Economic } \\
\text { problems }\end{array}$ & $\begin{array}{l}\text { Lack of } \\
\text { security }\end{array}$ & Others & $\begin{array}{l}\text { Multiple } \\
\text { answers }\end{array}$ & $\begin{array}{l}\text { No } \\
\text { comment }\end{array}$ & $\begin{array}{l}\text { Not } \\
\text { application }\end{array}$ & Total \\
\hline \multirow{8}{*}{$\begin{array}{l}\text { Illiterate } \\
\text { Can only read } \\
\text { Read \& write both } \\
\text { Educated till primary } \\
\text { Till high school } \\
\text { Above school level } \\
\text { No comment } \\
\text { Total }\end{array}$} & 16 & 120 & 43 & 4 & 34 & 2 & 2 & 221 \\
\hline & 3 & 18 & 4 & 2 & 10 & & & 37 \\
\hline & 4 & 25 & 13 & 3 & 27 & 1 & & 73 \\
\hline & 15 & 33 & 10 & 4 & 16 & 1 & & 79 \\
\hline & 15 & 44 & 18 & 5 & 9 & 2 & 2 & 95 \\
\hline & 3 & 8 & 5 & 1 & 5 & & & 22 \\
\hline & & 1 & & & & & & 1 \\
\hline & 56 & 249 & 93 & 19 & 101 & 6 & 4 & 528 \\
\hline
\end{tabular}




\subsection{Knowledge of Policy Mechanisms}

\begin{tabular}{|c|c|c|c|c|c|c|c|c|}
\hline \multirow[b]{2}{*}{ Literacy Level } & \multicolumn{8}{|c|}{ Knowledge of Policy Mechanisms } \\
\hline & $\begin{array}{l}\text { Multiple } \\
\text { answers }\end{array}$ & $\begin{array}{l}\text { Local } \\
\text { (Yes) }\end{array}$ & $\begin{array}{l}\text { Local } \\
\text { (No) }\end{array}$ & $\begin{array}{l}\text { National } \\
\text { (Yes) }\end{array}$ & $\begin{array}{l}\text { Inter- } \\
\text { National } \\
(\mathrm{No})\end{array}$ & $\begin{array}{l}\text { No } \\
\text { comment }\end{array}$ & $\begin{array}{l}\text { Not } \\
\text { application }\end{array}$ & Total \\
\hline \multirow{8}{*}{$\begin{array}{l}\text { Illiterate } \\
\text { Can only read } \\
\text { Read \& write both } \\
\text { Educated till primary } \\
\text { Till high school } \\
\text { Above school level } \\
\text { No comment } \\
\text { Total }\end{array}$} & 53 & 19 & 90 & & 1 & 12 & 46 & 221 \\
\hline & 20 & 5 & 10 & & & 1 & 1 & 37 \\
\hline & 39 & 7 & 21 & & & 4 & 2 & 73 \\
\hline & 28 & 5 & 28 & 1 & & 16 & 1 & 79 \\
\hline & 44 & 7 & 34 & & & 10 & & 95 \\
\hline & 7 & 1 & 14 & & & & & 22 \\
\hline & & & 1 & & & & & 1 \\
\hline & 191 & 44 & 198 & 1 & 1 & 43 & 50 & 528 \\
\hline
\end{tabular}




\section{Does the Causes of Displacement have an Impact on Other Factors in the IDP Life?}

\subsection{Duration of Displacement}

\begin{tabular}{|c|c|c|c|c|c|c|}
\hline \multirow[b]{2}{*}{ Causes of Displacement } & \multicolumn{6}{|c|}{ Duration of Displacement } \\
\hline & $\begin{array}{l}\text { One year } \\
\text { or less }\end{array}$ & $\begin{array}{l}\text { Between 1- } \\
3 \text { yrs. }\end{array}$ & $\begin{array}{l}\text { Between } \\
3-5 \text { yrs }\end{array}$ & $\begin{array}{l}\text { Above } 5 \\
\text { years }\end{array}$ & $\begin{array}{l}\text { No } \\
\text { comment }\end{array}$ & Total \\
\hline \multirow{9}{*}{$\begin{array}{l}\text { Natural disaster } \\
\text { Development projects } \\
\text { Armed conflict } \\
\text { Army occupation } \\
\text { Others } \\
\text { Multiple answers } \\
\text { No comment/No answer } \\
\text { Not applicable } \\
\text { Total }\end{array}$} & 53 & & 5 & 8 & & 66 \\
\hline & 1 & 17 & 13 & 60 & & 91 \\
\hline & 33 & 16 & 52 & 134 & & 235 \\
\hline & & 4 & 8 & 22 & & 34 \\
\hline & 1 & 6 & 47 & 19 & & 73 \\
\hline & 4 & 2 & 13 & 7 & & 26 \\
\hline & & & 1 & & 1 & 2 \\
\hline & & 1 & & & & 1 \\
\hline & 92 & 46 & 139 & 250 & 1 & 528 \\
\hline
\end{tabular}

\subsection{Type of Support Available}

\begin{tabular}{|c|c|c|c|c|c|c|c|c|c|}
\hline \multirow[b]{2}{*}{ Causes of Displacement } & \multicolumn{9}{|c|}{ Type of Support } \\
\hline & $\begin{array}{l}\text { Economic } \\
\text { support }\end{array}$ & Shelter & Food & $\begin{array}{l}\text { Educ } \\
\text { ation }\end{array}$ & Health & Others & $\begin{array}{l}\text { Multiple } \\
\text { support }\end{array}$ & $\begin{array}{l}\text { Not } \\
\text { available }\end{array}$ & Total \\
\hline \multirow{9}{*}{$\begin{array}{l}\text { Natural disaster } \\
\text { Development projects } \\
\text { Armed conflict } \\
\text { Army occupation } \\
\text { Others } \\
\text { Multiple answers } \\
\text { No comment/No answer } \\
\text { Not applicable } \\
\text { Total }\end{array}$} & 1 & & 4 & & & & 49 & 12 & 66 \\
\hline & 8 & 16 & 1 & & 1 & & 22 & 43 & 91 \\
\hline & 11 & 7 & 40 & & 3 & 1 & 48 & 125 & 235 \\
\hline & 5 & & 6 & & & 7 & 3 & 13 & 34 \\
\hline & 5 & 3 & 1 & 3 & & 1 & 39 & 21 & 73 \\
\hline & 1 & & 3 & & & 1 & 16 & 5 & 26 \\
\hline & & & & & & & & 2 & 2 \\
\hline & & & 1 & & & & & & 1 \\
\hline & 31 & 26 & 56 & 3 & 4 & 10 & 177 & 221 & 528 \\
\hline
\end{tabular}

\subsection{Major Concerns}

\begin{tabular}{|c|c|c|c|c|c|}
\hline \multirow[b]{2}{*}{ Causes of Displacement } & \multicolumn{5}{|c|}{ Major Concerns } \\
\hline & $\begin{array}{l}\text { No } \\
\text { allowance }\end{array}$ & $\begin{array}{l}\text { Lack of } \\
\text { security }\end{array}$ & $\begin{array}{l}\text { Lack of } \\
\text { amenities }\end{array}$ & Others & $\begin{array}{l}\text { Multiple } \\
\text { concern }\end{array}$ \\
\hline \multirow{9}{*}{$\begin{array}{l}\text { Natural disaster } \\
\text { Development projects } \\
\text { Armed conflict } \\
\text { Army occupation } \\
\text { Others } \\
\text { Multiple answers } \\
\text { No comment/No answer } \\
\text { Not applicable } \\
\text { Total }\end{array}$} & 3 & & 22 & 12 & 7 \\
\hline & 14 & 6 & 6 & & 3 \\
\hline & & 12 & 21 & & 39 \\
\hline & 1 & 1 & 1 & & 2 \\
\hline & 16 & & & & 1 \\
\hline & & & 3 & 1 & 7 \\
\hline & & & & & \\
\hline & & & & & \\
\hline & 34 & 19 & 53 & 13 & 59 \\
\hline
\end{tabular}




\subsection{Feelings about Probability for Return}

\begin{tabular}{|c|c|c|c|c|c|}
\hline \multirow[b]{2}{*}{ Causes of Displacement } & \multicolumn{5}{|c|}{ Probability of Return } \\
\hline & Yes & No & No comment & $\begin{array}{l}\text { Not } \\
\text { applicable }\end{array}$ & Total \\
\hline \multirow{9}{*}{$\begin{array}{l}\text { Natural disaster } \\
\text { Development projects } \\
\text { Armed conflict } \\
\text { Army occupation } \\
\text { Others } \\
\text { Multiple answers } \\
\text { No comment/No answer } \\
\text { Not applicable } \\
\text { Total }\end{array}$} & 23 & 41 & 2 & & 66 \\
\hline & 8 & 83 & & & 91 \\
\hline & 89 & 139 & 5 & 2 & 235 \\
\hline & 7 & 27 & & & 34 \\
\hline & 5 & 62 & 6 & & 73 \\
\hline & 14 & 8 & & 4 & 26 \\
\hline & & 1 & 1 & & 2 \\
\hline & & 1 & & & 1 \\
\hline & 146 & 362 & 14 & 6 & 528 \\
\hline
\end{tabular}

\subsection{Knowledge of Policy Mechanism}

\begin{tabular}{|c|c|c|c|c|c|c|c|c|}
\hline \multirow[t]{2}{*}{ Causes of Displacement } & \multicolumn{8}{|c|}{ Knowledge of Policy Mechanism } \\
\hline & $\begin{array}{l}\text { Multiple } \\
\text { answer }\end{array}$ & $\begin{array}{l}\text { Local } \\
\text { (Yes) }\end{array}$ & $\begin{array}{l}\text { Local } \\
\text { (No) }\end{array}$ & $\begin{array}{l}\text { National } \\
\text { (Yes) }\end{array}$ & $\begin{array}{l}\text { International } \\
\text { (Yes) }\end{array}$ & $\begin{array}{l}\text { No } \\
\text { comment }\end{array}$ & $\begin{array}{l}\text { No } \\
\text { applicable }\end{array}$ & Total \\
\hline \multirow{9}{*}{$\begin{array}{l}\text { Natural disaster } \\
\text { Development projects } \\
\text { Armed conflict } \\
\text { Army occupation } \\
\text { Others } \\
\text { Multiple answers } \\
\text { No comment/No answer } \\
\text { Not applicable } \\
\text { Total }\end{array}$} & 31 & & 3 & & & 31 & 1 & 66 \\
\hline & 1 & & 41 & & & 1 & 48 & 91 \\
\hline & 120 & & 112 & & 1 & 2 & & 235 \\
\hline & 2 & 2 & 30 & & & & & 34 \\
\hline & 21 & 41 & 3 & 1 & & 7 & & 73 \\
\hline & 16 & & 9 & & & 1 & & 26 \\
\hline & & 1 & & & & 1 & & 2 \\
\hline & & & & & & & 1 & 1 \\
\hline & 191 & 44 & 198 & 1 & 1 & 43 & 50 & 528 \\
\hline
\end{tabular}




\section{Recommendations}

1. There is a need to have national resettlement policies in all countries of South Asia, and these policies should cover displacements due to violence and environmental-developmental reasons both.

2. Consultative mechanisms have to be devised so that in the formulation of policies for the relief and rehabilitation of the IDPs by the government institutions and national and international NGOs, the experiences, opinions and preferences of the displaced themselves are given utmost priority.

3. State surveys should be conducted in all countries of the region in order to have a comprehensive idea about the nature and magnitude of displacement. These surveys should not be bureaucratically planned; they should be planned in a consultative and deliberative way.

4. The national human rights institutions have to be sensitised more about the perils of the IDPs in the respective countries. These institutions can contribute significantly to the formulation of the national IDP policies.

5. In order to make people aware of the rights of the IDPs, more popular-level campaigns need to be organised.

6. Apart from the national policies on IDPs, a South Asian regional policy on the IDPs would also be crucial. A mechanism to monitor the situation of the IDPs at the regional level may also be considered.

7. So far as the IDPs sheltered in the makeshift camps are concerned, there is a need for looking after the educational and health-related facilities in these camps. It is also important to devise policies on sanitation of the camps. The security of the camp-dwellers has also to be ensured.

8. The obligation to resettle should be considered as equally important as the displaced persons' right to return.

9. Special attention must be paid to female-headed households.

10. Special policy has to be devised for the rehabilitation of the IDPs not taking shelter in the camps.

11. A legal recognition of the IDPs as a category is absolutely necessary. Without this recognition at the national level, it would be difficult to ensure the basic rights of the IDPs.

12. Finally, international mechanisms have to be popularised to a much greater extent; and attention must be paid to the responsibility of national and international actors in provoking displacement by their actions. Regular sessions of a working group on the IDPs attached to the Human Rights Commission will have experts' and victims' participation, and will thus strengthen the hands of the Representative of the UN Secretary General dealing with the rights of the IDPs. 